\title{
Photoinduced Hydrocarboxylation via Thiol-Catalyzed Delivery of Formate Across Activated Alkenes
}

Sara N. Alektiar and Zachary K. Wickens*

Department of Chemistry, University of Wisconsin-Madison, Madison, Wisconsin 53706, United States

\section{Supporting Information}

1. General Methods and Materials 2

2. Experimental Set-Up 3

3. Reaction Optimization Tables 4

4. Unsuccessful Substrates 14

5. Limiting $\mathrm{Na}^{13} \mathrm{CO}_{2} \mathrm{H}$ Reaction Optimization Tables 15

6. Starting Material and Catalyst Synthesis 17

7. General Experimental Procedures 20

8. Product Isolation and Characterization $\quad 22$

9. Scale-Up Setup-up and Procedure 28

10. Synthesis of bioactive molecules under standard conditions $\quad 30$

11. ${ }^{13} \mathrm{C}$ Labeling Procedure $\quad 32$

12. Deuterium Labeling Procedure 34

13. GC Calibration Curves 36

14. Stern-Volmer $\quad 40$

15. Cyclic Voltammetry 41

16. $\mathrm{KCHO}_{2}$ Solubility Test 42

17. References 43

18. NMR Spectra 45 


\section{General Methods and Materials}

Unless otherwise noted, no precautions were taken to exclude air and were run using anhydrous solvent. Anhydrous DMSO was purchased from DriSolv. All alkene reagents were passed through a short basic alumina plug immediately prior to use. Unless otherwise noted, other commerciallyavailable reagents were used as received. Irradiation of photochemical reactions was carried out using Kessil LED lamps (467 nm [KSPR160L-467]. Crude mixtures were evaluated by thin-layer chromatography using EMD/Merck silica gel $60 \mathrm{~F} 254$ pre-coated plates $(0.25 \mathrm{~mm})$ and were visualized by $\mathrm{UV}, \mathrm{KMnO}_{4}$, and Bromocresol Green staining. Flash chromatography was performed with a Biotage Isolera One automated chromatography system with re-packed silica columns (technical grade silica, pore size $60 \AA$, 230-400 mesh particle size, 40-63 particle size). Purified materials were dried in vacuo ( 0.050 Torr) to remove trace solvent. ${ }^{1} \mathrm{H}$ and ${ }^{13} \mathrm{C}$ Spectra were collected using a Bruker Avance-400 with a BBFO Probe, Bruker Avance-500 with a DCH Cryoprobe, or a Bruker Avance III HD-500 with TXO Cryoprobe. NMR data are reported relative to residual $\mathrm{CHCl}_{3}\left({ }^{1} \mathrm{H}, \delta=7.26 \mathrm{ppm}\right), \mathrm{CDCl}_{3}\left({ }^{13} \mathrm{C}, \delta=77.16 \mathrm{ppm}\right)$ or DMSO- $\mathrm{d}^{6}\left({ }^{1} \mathrm{H}, \delta=2.50\right.$ $\mathrm{ppm}$ ). Data for ${ }^{1} \mathrm{H}$ NMR spectra are reported as follows: chemical shift $(\delta \mathrm{ppm})$ (multiplicity, coupling constant $(\mathrm{Hz})$, integration). Multiplicity and qualifier abbreviations are as follows: $\mathrm{s}=$ singlet, $\mathrm{d}=$ doublet, $\mathrm{t}=$ triplet, $\mathrm{q}=$ quartet, $\mathrm{m}=$ multiplet, $\mathrm{br}=$ broad. All NMR yields were determined via reference against an internal standard (dibromomethane for ${ }^{1} \mathrm{H} \mathrm{NMR}$ ). $\mathrm{GC}$ traces were taken on an Agilent 7890A GC with dual DB-5 columns $(20 \mathrm{~m} \times 180 \mu \mu \mathrm{m} \times 0.18 \mu \mathrm{m})$, dual FID detectors, and hydrogen as the carrier gas. A sample volume of $2 \mu \mathrm{L}$ was injected at a temperature of $300{ }^{\circ} \mathrm{C}$ and a 100:1 split ratio. The initial inlet pressure was 20.3 psi but varied as the column flow was held constant at $1.8 \mathrm{~mL} / \mathrm{min}$ for the duration of the run, FID temperature was $325^{\circ} \mathrm{C}$. 


\section{Experimental Set-Up}

For 0.1 and $0.4 \mathrm{mmol}$ scale reactions, a cell rack was used to hold the reaction vials. For $1 \mathrm{mmol}$ scale reactions, the vial was taped to the stir plate using electrical tape

0.1 and $0.4 \mathrm{mmol}$ scale setup

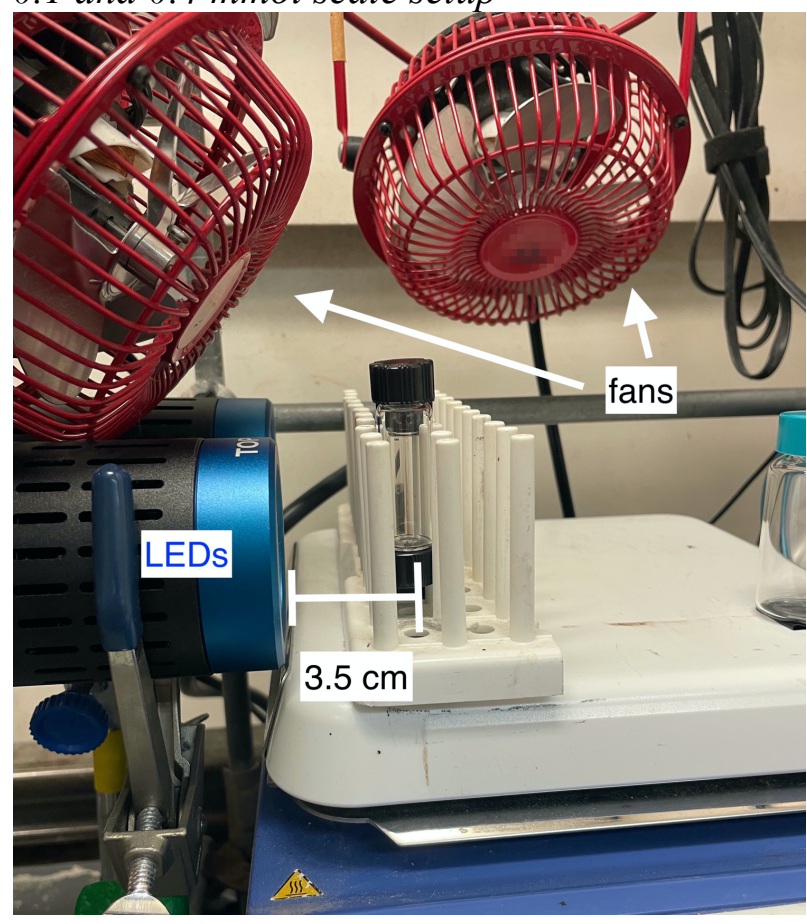

\section{1 mmol scale setup}

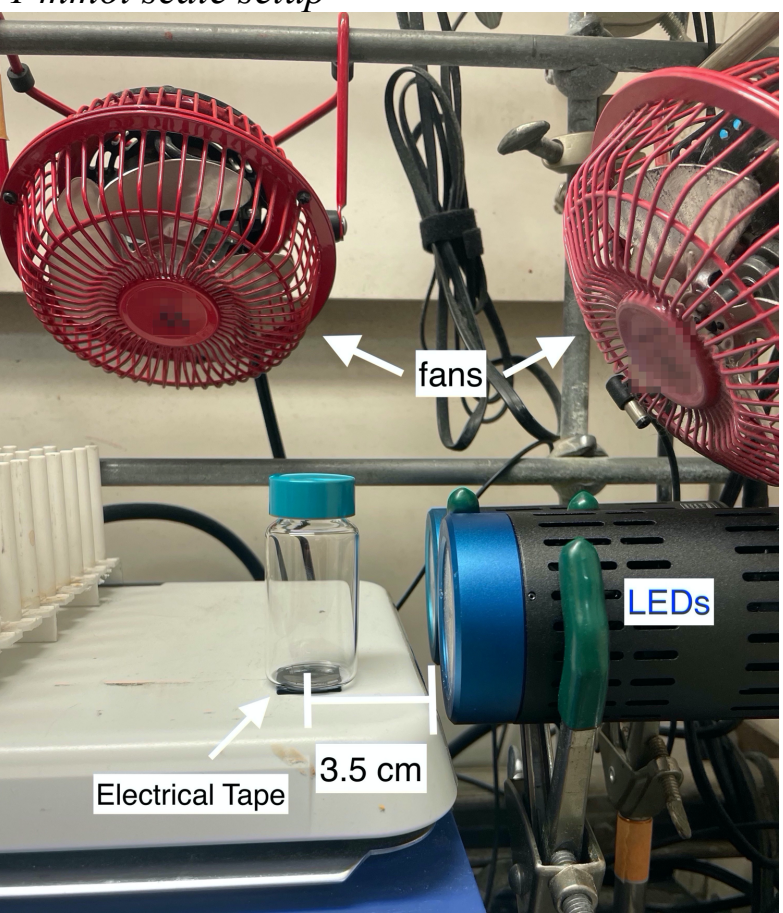

\section{Running Reactions}

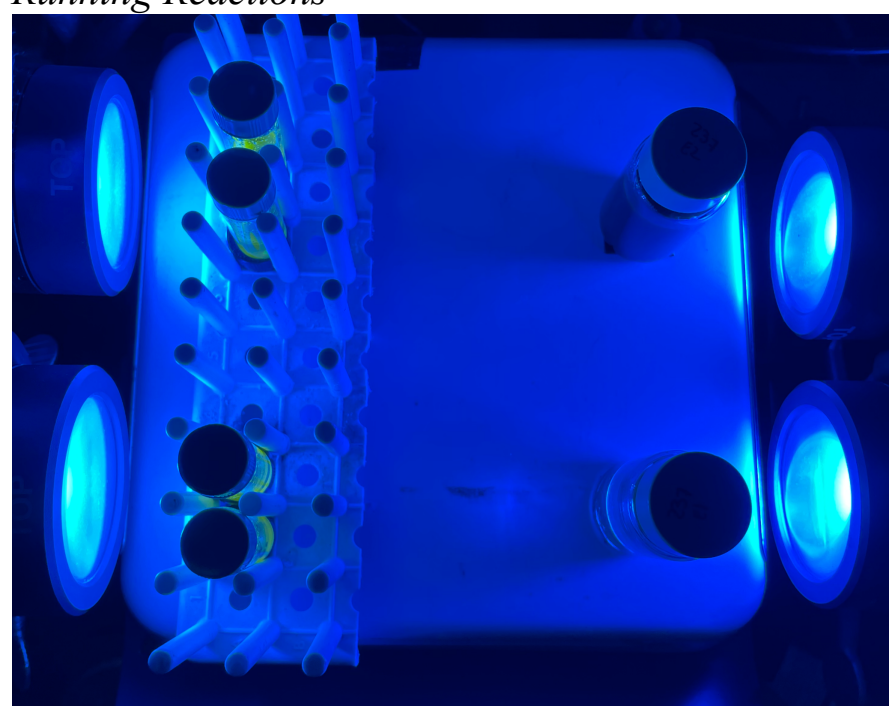

Figure S1. Standard setup for photoredox reactions. See General Experimental Procedures for details. 


\section{Reaction Optimization Tables}

General Procedure: Styrene was used as the model substrate to optimize the reaction conditions. Conversion was monitored via GC as conversion of styrene was found to track with yield.

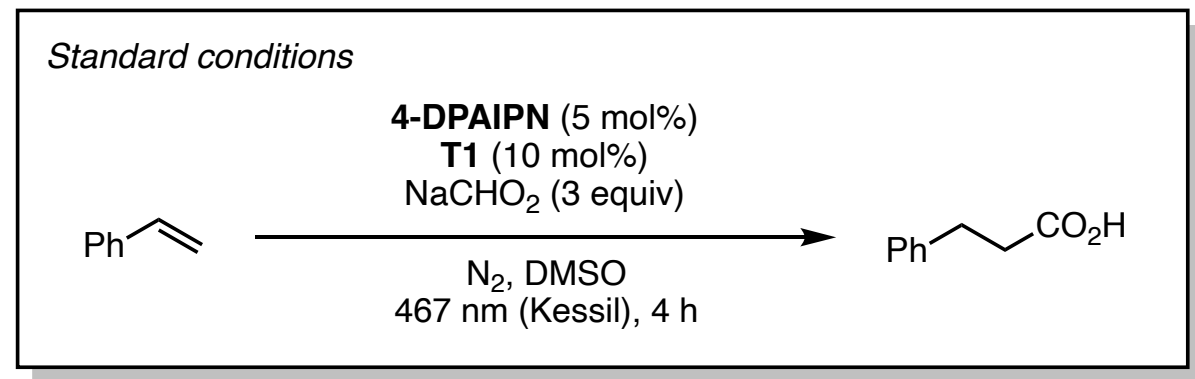

Standard conditions: Sodium formate $(20.4 \mathrm{mg}, 3.00$ equiv, $0.30 \mathrm{mmol}$ ) and 4DPAIPN (4.0 mg, 0.05 equiv, $5.00 \mu \mathrm{mol}$ ) were added to a $10 \mathrm{~mL}$ schlenk tube (dried in oven, cooled in desiccator). Styrene* $(11.5 \mu \mathrm{L}, 1.00$ equiv, $0.10 \mathrm{mmol})$, methyl thiosalicylate $(1.4 \mu \mathrm{L}, 0.10$ equiv, $10.00 \mu \mathrm{mol})$, and $1.5 \mathrm{~mL}$ DMSO were added. The reaction mixture was then freeze-pump-thawed $3 \mathrm{x}$ and sealed under $\mathrm{N}_{2}$. With fan cooling, irradiate with $467 \mathrm{~nm}$ Kessil for $4 \mathrm{~h}$. After the reaction was complete, dibenzylether $(19.0 \mu \mathrm{L}, 1.00$ equiv, $0.10 \mathrm{mmol})$ was added as a standard to monitor conversion via GC.

*Filter off the inhibitor by passing through $\sim 1$ in basic alumina immediately prior to use.

Thiol screen

Table S1. Thiol evaluation

\begin{tabular}{l|r|}
\multicolumn{1}{c}{ except thiol } & standard conditions \\
Thiol & \% conv \\
\hline no thiol & 14 \\
\hline adamantane-thiol & 13 \\
\hline tBuSH & 31 \\
\hline CySH & 11 \\
\hline 1-decanethiol & 47 \\
\hline Mesna & 54 \\
\hline methyl thioglycolate & 100 \\
\hline PhSH & 98 \\
\hline 2-methoxybenzenethiol & 68 \\
\hline 4-methoxybenzenethiol & 27 \\
\hline methyl thiosalicylate & 100 \\
\hline methyl 4-mercaptobenzoate & 100 \\
\hline
\end{tabular}

The reactions were conducted following standard conditions except varying the thiol identity and no precautions to exclude air were taken. 
Table S2. Photocatalyst evaluation

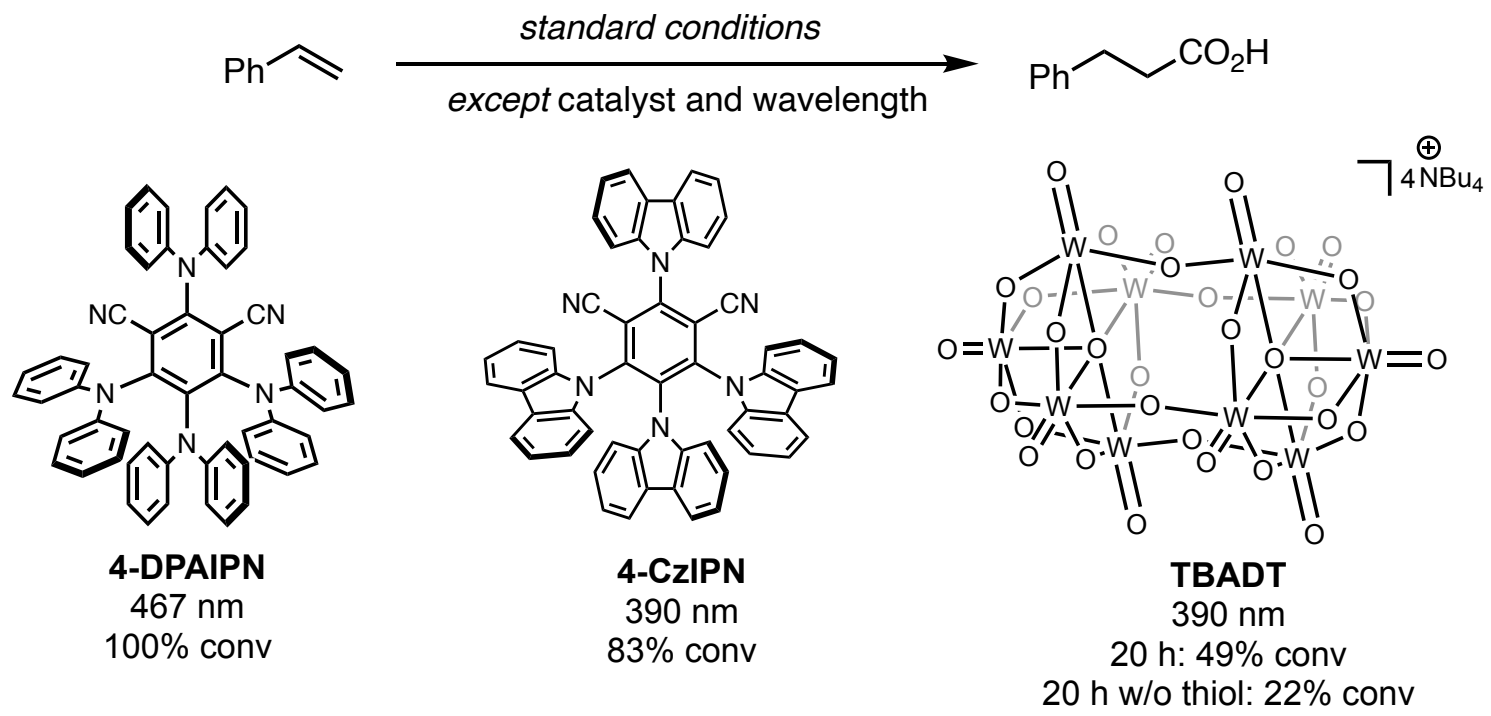<smiles>N#Cc1c2ccccc2c(C#N)c2ccccc12</smiles>
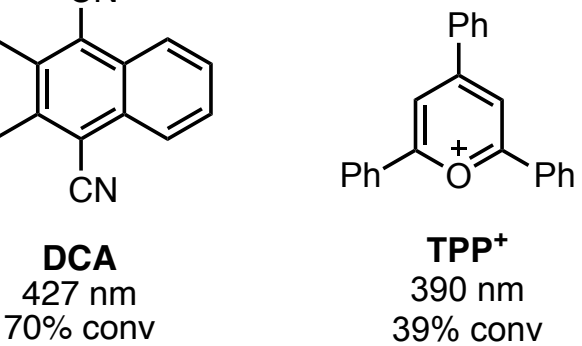

The reactions were conducted following standard conditions except varying the photocatalyst identity and wavelength used. 
Table S3. IrF optimization

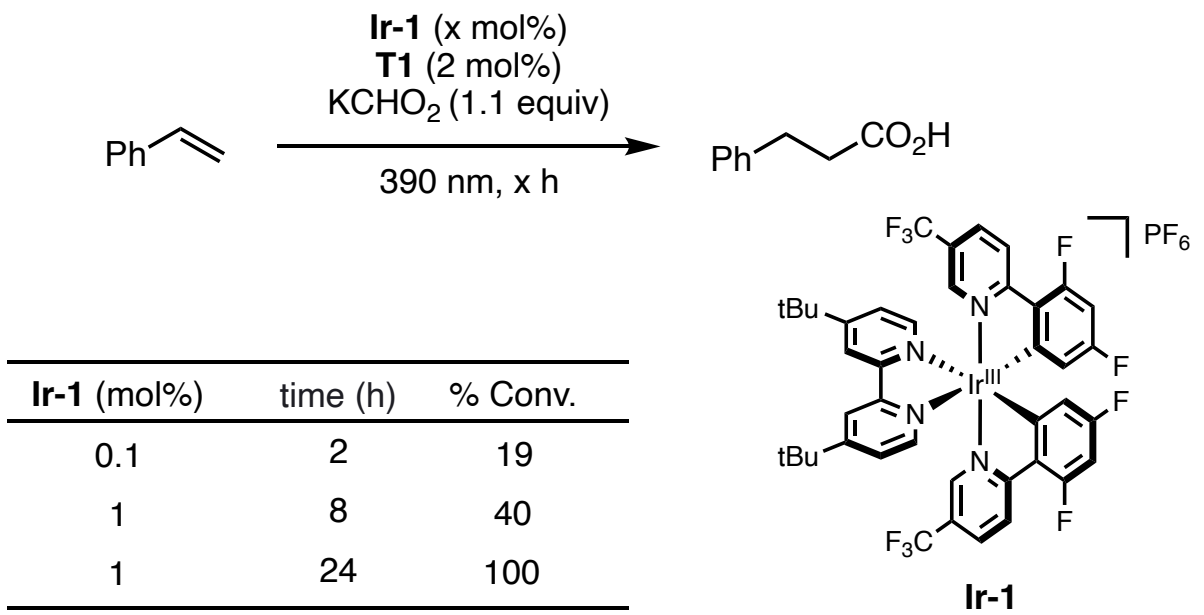

Potassium formate $(92.5 \mathrm{mg}, 1.1$ equiv, $1.10 \mathrm{mmol})$ and 4DPAIPN $(0.8 \mathrm{mg}, 0.001$ equiv, 1.00 $\mu \mathrm{mol})$ were added to a $40 \mathrm{~mL}$ scintillation vial (oven-dried, cooled in desiccator). The reaction vessel was sparged with an Ar balloon for 2 min. $15 \mathrm{~mL}$ DMSO was then added and the solution was sparged with an Ar balloon for $30 \mathrm{~min}$. Styrene* (115 $\mu \mathrm{L}, 1.00$ equiv, $1.00 \mathrm{mmol}$ ), methyl thiosalicylate $(2.8 \mu \mathrm{L}, 0.02$ equiv, $20.00 \mu \mathrm{mol})$, and mesitylene as an internal standard $(80.0 \mu \mathrm{L}$, 0.72 equiv, $0.72 \mathrm{mmol}$ ) were added to the vial. With fan cooling, irradiate with a $467 \mathrm{~nm}$ Kessil lamp for $2 \mathrm{~h}$.

*Filter off the inhibitor by passing through $\sim 1$ in basic alumina immediately prior to use.

\section{Solvent screen}

Table S4. Solvent evaluation

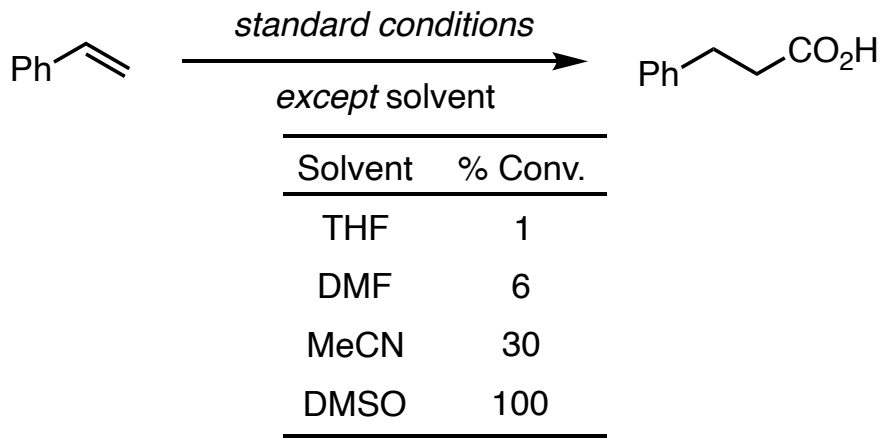

The reactions were conducted following standard conditions except varying the solvent used. 
Table S5. Formate evaluation

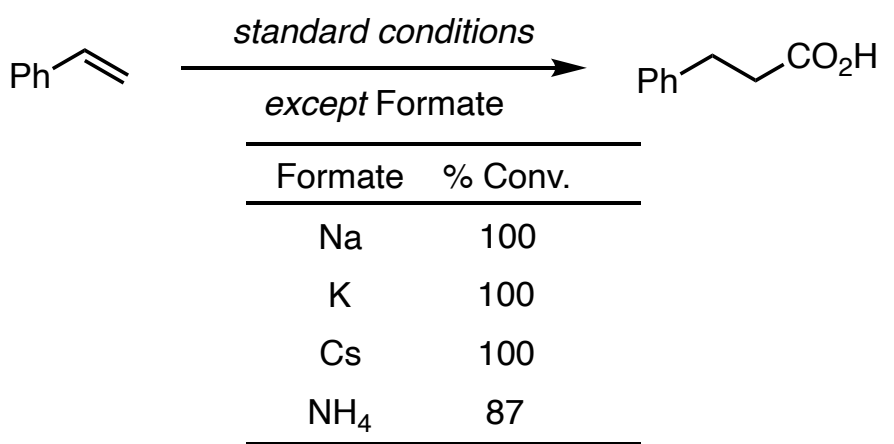

The reactions were conducted following standard conditions except varying the formate counterion.

Table S6. Formate evaluation at shortened time

\begin{tabular}{|c|c|c|}
\hline standá & Formate, & $\mathrm{h}$ \\
\hline Formate & $\%$ Conv. & Price $(\$) / \mathrm{mol}$ \\
\hline $\mathrm{Na}^{+}$ & 37 & 13.74 \\
\hline $\mathrm{K}^{+}$ & 53 & 10.16 \\
\hline $\mathrm{Cs}^{+}$ & 100 & 346.59 \\
\hline
\end{tabular}

The reactions were conducted following standard conditions except varying the formate counterion and shortening the time to $1 \mathrm{~h}$. Potassium was chosen as the optimal counterion due to its price $/ \mathrm{mol}$ and short reaction time (reaction is complete in $1.5 \mathrm{~h}$ on $0.1 \mathrm{mmol}$ scale).

Loading screen

Table S7. Photocatalyst and thiol loading screen

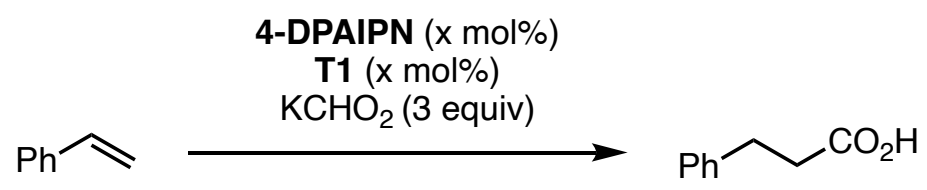




\begin{tabular}{r|r|r|}
\hline PC mol\% & thiol mol \% & \% Conv \\
\hline 5 & 2 & 100 \\
\hline 5 & 4 & 100 \\
\hline 5 & 10 & 100 \\
\hline 2 & 2 & 100 \\
\hline 2 & 4 & 100 \\
\hline 2 & 10 & 100 \\
\hline 0.1 & 2 & 59 \\
\hline 0.5 & 2 & 56 \\
\hline 1 & 2 & 73 \\
\hline 0.1 & 2 & 36 \\
\hline 0.5 & 2 & 63 \\
\hline 1 & 2 & 62 \\
\hline
\end{tabular}

Potassium formate ( $25.2 \mathrm{mg}, 3.00$ equiv, $0.30 \mathrm{mmol}$ ) and 4DPAIPN (varying loading) were added to a 1 dram vial (dried in oven, cooled in desiccator). Styrene* $(11.5 \mu \mathrm{L}, 1.00$ equiv, $0.10 \mathrm{mmol}$ ), methyl thiosalicylate (varying loading), and $1.5 \mathrm{~mL}$ DMSO were added. With fan cooling, irradiate with $467 \mathrm{~nm}$ Kessil for $4 \mathrm{~h}$. After the reaction was complete, dibenzylether $(19.0 \mu \mathrm{L}, 1.00$ equiv, $0.10 \mathrm{mmol}$ ) was added as a standard to monitor conversion via GC.

*Filter off the inhibitor by passing through $\sim 1$ in basic alumina immediately prior to use.

Table S8. Formate loading screen

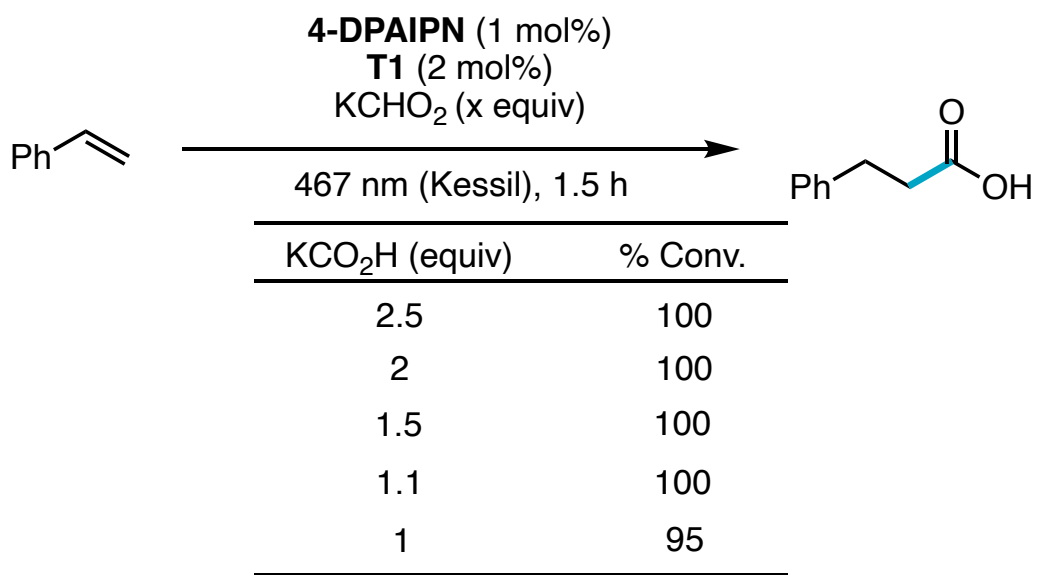

Potassium formate (varying loading) and 4DPAIPN ( $0.8 \mathrm{mg}, 0.001$ equiv, $1.00 \mu \mathrm{mol})$ were added to a $20 \mathrm{~mL}$ scintillation vial (oven-dried, cooled in desiccator). Styrene* (115 $\mu \mathrm{L}, 1.00$ equiv, 1.00 mmol), methyl thiosalicylate $(2.8 \mu \mathrm{L}, 0.02$ equiv, $20.00 \mu \mathrm{mol})$, mesitylene as an internal standard $(80.0 \mu \mathrm{L}, 0.72$ equiv, $0.72 \mathrm{mmol}$ ), and $15 \mathrm{~mL}$ DMSO were added to the vial and capped with a teflon cap. With fan cooling, irradiate with a $467 \mathrm{~nm}$ Kessil lamp for $2 \mathrm{~h}$.

*Filter off the inhibitor by passing through $\sim 1$ in basic alumina immediately prior to use. 
Scheme S1. No light control

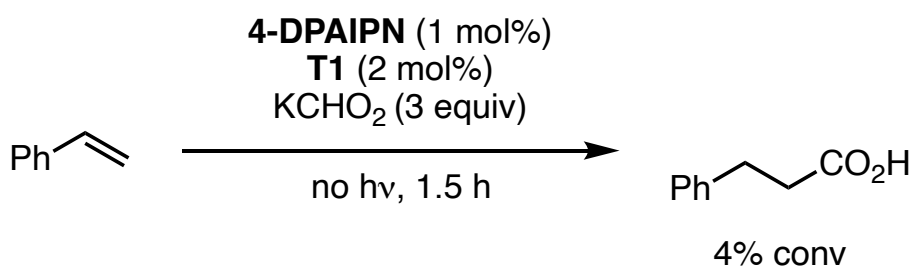

Potassium formate $(25.2 \mathrm{mg}, 3.00$ equiv, $0.30 \mathrm{mmol})$ and 4DPAIPN $(0.8 \mathrm{mg}, 0.01$ equiv, 1.00 $\mu \mathrm{mol})$ were added to a $20 \mathrm{~mL}$ scintillation vial (oven-dried, cooled in desiccator). Styrene* (11.5 $\mu \mathrm{L}, 1.00$ equiv, $0.10 \mathrm{mmol})$, methyl thiosalicylate $(0.3 \mu \mathrm{L}, 0.02$ equiv, $2.00 \mu \mathrm{mol})$, mesitylene as an internal standard $(10.0 \mu \mathrm{L}, 0.58$ equiv, $58.0 \mu \mathrm{mol})$, and $1.5 \mathrm{~mL}$ DMSO were added to the vial and capped with a teflon cap. The vial was then wrapped in foil so no glass was exposed. With fan cooling, irradiate with a $467 \mathrm{~nm}$ Kessil lamp for $1.5 \mathrm{~h}$.

*Filter off the inhibitor by passing through $\sim 1$ in basic alumina immediately prior to use.

Translating conditions from our previous work ${ }^{1}$

Scheme S2. Conditions from previous work

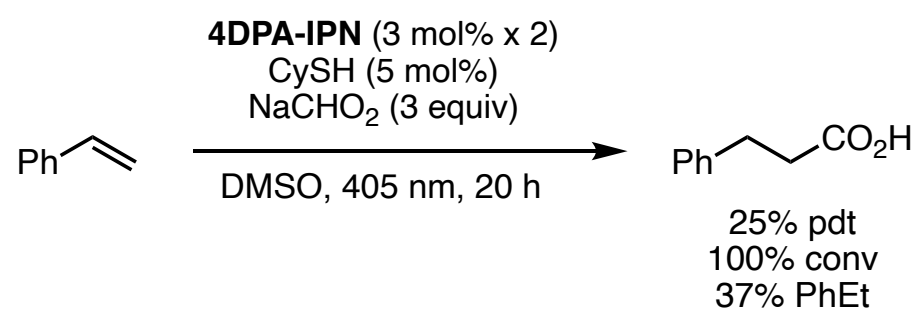

4DPAIPN (2.39 mg, 0.03 equiv, $3.00 \mu \mathrm{mol})$ and $\mathrm{NaCHO}_{2}(20.4 \mathrm{mg}, 3$ equiv, $300 \mu \mathrm{mol})$ were added to an oven-dried $10 \mathrm{~mL}$ schlenk tube equipped with stir bar. The tube was evacuated and backfilled with $\mathrm{N}_{2}$ three times. While under active $\mathrm{N}_{2}$, cyclohexane thiol $(0.6 \mu \mathrm{L}, 0.05$ equiv, 5.00 $\mu \mathrm{mol})$, styrene* $(11.5 \mu \mathrm{L}, 1.0$ equiv, $0.10 \mathrm{mmol})$, mesitylene ( $10.0 \mu \mathrm{L}, 0.72$ equiv, $0.72 \mathrm{mmol})$ as an internal standard, and DMSO $(0.5 \mathrm{~mL})$ were added. The tube was sealed under $\mathrm{N}_{2}$ then stirred and irradiated with a $405 \mathrm{~nm}$ lamp ( $4.5 \mathrm{~cm}$ from glass surface with fan cooling) for 20 hours total. At the 6 hour mark, an additional $3 \mathrm{~mol} \%$ 4DPAIPN was added as a stock solution $(3 \mathrm{~mol} \%$ 4DPAIPN dissolved in $100 \mathrm{uL}$ DMSO - then to the reaction vessel, evacuated and backfilled with $\mathrm{N}_{2}$ on the side arm then while under active $\mathrm{N}_{2}$, added the stock solution). The tube was resealed under $\mathrm{N}_{2}$ and stirred while irradiating for the remaining 14 hours.

*Filter off the inhibitor by passing through $\sim 1$ in basic alumina immediately prior to use.

Scheme S3. Conditions from previous work shortened

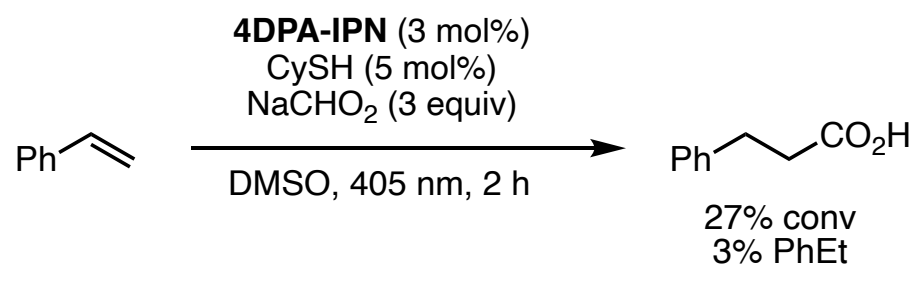


The above procedure from our previous work was followed except no catalyst batch was added and the reaction was stopped after $2 \mathrm{~h}$.

\section{Radical initiators}

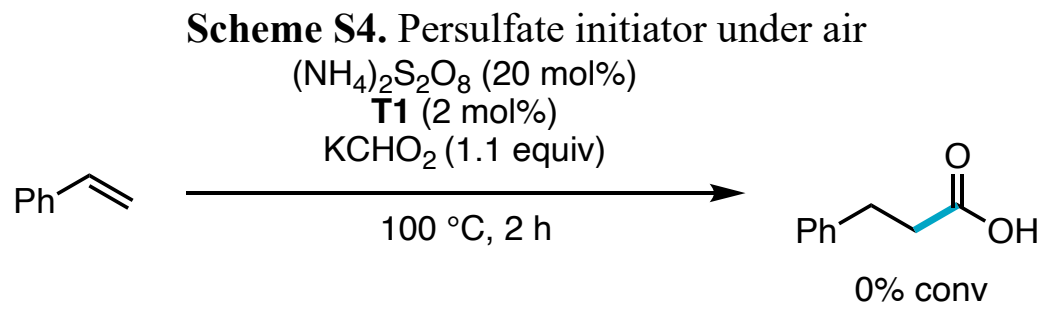

Potassium formate $(92.5 \mathrm{mg}, 1.1$ equiv, $1.10 \mathrm{mmol}$ ) and Ammonium peroxydisulfate (45.6 $\mathrm{mg}$, $23.0 \mu \mathrm{L}, 0.2$ equiv, $200 \mu \mathrm{mol}$ ) were added to a $40 \mathrm{~mL}$ scin vial (oven-dried, cooled in desiccator). Styrene* $(115 \mu \mathrm{L}, 1.0$ equiv, $1.00 \mathrm{mmol})$, Methyl 2-sulfanylbenzoate (2.8 $\mu \mathrm{L}, 0.020$ equiv, 20 $\mu \mathrm{mol})$, Mesitylene $(80.0 \mu \mathrm{L}, 0.58$ equiv, $576 \mu \mathrm{mol})$, and $15 \mathrm{~mL}$ DMSO were added to the vial and capped with a teflon cap. The reaction was heated to $100{ }^{\circ} \mathrm{C}$ for $2 \mathrm{~h}$.

*Filter off the inhibitor by passing through $\sim 1$ in basic alumina immediately prior to use.

Scheme S5. Persulfate initiator under $\mathrm{N}_{2}$

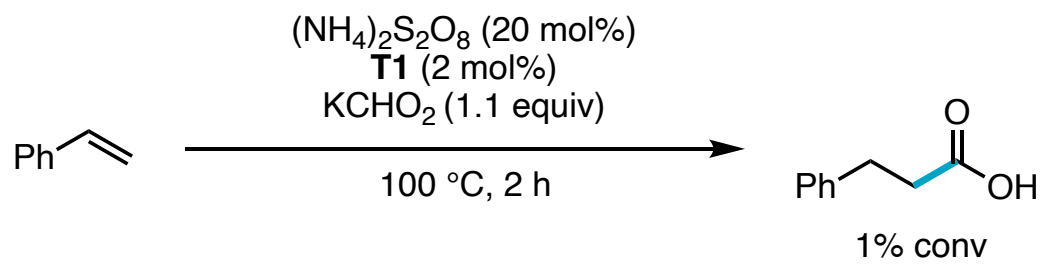

The above persulfate procedure was followed except the reaction was freeze-pump-thawed $3 \mathrm{x}$ and sealed under $\mathrm{N}_{2}$.

Scheme S6. Disulfide initiator under air

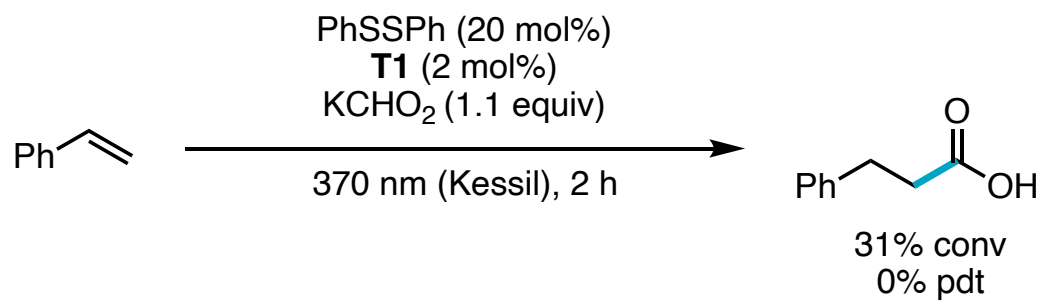

Potassium formate $(92.5 \mathrm{mg}, 1.1$ equiv, $1.10 \mathrm{mmol})$ and Diphenyl disulfide $(43.7 \mathrm{mg}, 0.20$ equiv, $0.20 \mathrm{mmol}$ ) were added to a $20 \mathrm{~mL}$ scin vial (oven-dried, cooled in desiccator). Styrene* (115 $\mu \mathrm{L}, 1.0$ equiv, $1.00 \mathrm{mmol})$, Methyl 2-sulfanylbenzoate $(2.8 \mu \mathrm{L}, 0.020$ equiv, $20 \mu \mathrm{mol})$, Mesitylene $(80.0 \mu \mathrm{L}, 0.58$ equiv, $576 \mu \mathrm{mol})$, and $15 \mathrm{~mL}$ DMSO were added to the vial and capped with a teflon cap. With fan cooling, irradiate with a $370 \mathrm{~nm}$ Kessil lamp for $2 \mathrm{~h}$. *Filter off the inhibitor by passing through $\sim 1$ in basic alumina immediately prior to use.

Reaction mixture was transferred to a $500 \mathrm{~mL}$ sep funnel with $2 \times 2 \mathrm{~mL}$ EtOAc, $2 \times 2 \mathrm{~mL} 10 \% \mathrm{HCl}$ $20 \%$ brine aq solution, $2 \times 2 \mathrm{~mL}$ EtOAc. $250 \mathrm{~mL} \mathrm{10 \%} \mathrm{HCl} 20 \%$ brine aq solution was added and 
the mixture was extracted $3 \times 100 \mathrm{~mL}$ EtOAc. Combined organic layers were washed with $3 \times 75$ $\mathrm{mL} \mathrm{NaHCO}_{3}$ (collected in a separate flask from brine aq layer). The neutralized aq layer was acidified with conc $\mathrm{HCl}$ until $\mathrm{pH}=1$ (bright pink on $\mathrm{pH}$ paper). The aq was then extracted $1 \times 100$ and $3 \times 50 \mathrm{~mL}$ EtOAc. Combined organic layers were dried over $\mathrm{Na}_{2} \mathrm{SO}_{4}$ and $\mathrm{MgSO}_{4}$ and concentrated. $\mathrm{CH}_{2} \mathrm{Br}_{2}(70 \mathrm{uL}, 1.0$ equiv, $0.10 \mathrm{mmol})$ was added as an internal standard and the yield was quantified via ${ }^{1} \mathrm{H}$ NMR.

\section{Variation table (Table 1)}

General Procedure: Potassium formate $(92.5 \mathrm{mg}, 1.1$ equiv, $1.10 \mathrm{mmol})$ and 4DPAIPN $(0.8 \mathrm{mg}$, 0.001 equiv, $1.00 \mu \mathrm{mol}$ ) were added to a $20 \mathrm{~mL}$ scintillation vial (oven-dried, cooled in desiccator). Styrene* $(115 \mu \mathrm{L}, 1.00$ equiv, $1.00 \mathrm{mmol})$, methyl thiosalicylate $(2.8 \mu \mathrm{L}, 0.02$ equiv, $20.00 \mu \mathrm{mol})$, mesitylene as an internal standard $(0.58$ equiv, $576 \mu \mathrm{mol})$, and $15 \mathrm{~mL}$ of DMSO were added to the vial and capped with a teflon cap. With fan cooling, irradiate with a $467 \mathrm{~nm}$ Kessil lamp for $2 \mathrm{~h}$. *Filter off the inhibitor by passing through $\sim 1$ in basic alumina immediately prior to use.

Reaction mixture was transferred to a $500 \mathrm{~mL}$ sep funnel with $2 \times 2 \mathrm{~mL}$ EtOAc, $2 \times 2 \mathrm{~mL} \mathrm{10 \%} \mathrm{HCl}$ $20 \%$ brine aq solution, $2 \times 2 \mathrm{~mL}$ EtOAc. $250 \mathrm{~mL} \mathrm{10 \%} \mathrm{HCl} 20 \%$ brine aq solution was added and the mixture was extracted $3 \times 100 \mathrm{~mL}$ EtOAc. Combined organic layers were washed with $3 \times 75$ $\mathrm{mL} \mathrm{NaHCO}_{3}$ (collected in a separate flask from brine aq layer). The neutralized aq layer was acidified with conc $\mathrm{HCl}$ until $\mathrm{pH}=1$ (bright pink on $\mathrm{pH}$ paper). The aq was then extracted 1x100 $\mathrm{mL}$ and 3x50 mL EtOAc. Combined organic layers were dried over $\mathrm{Na}_{2} \mathrm{SO}_{4}$ and $\mathrm{MgSO}_{4}$ and concentrated. $\mathrm{CH}_{2} \mathrm{Br}_{2}(70 \mathrm{uL}, 1.0$ equiv, $1.00 \mathrm{mmol})$ was added as an internal standard and the yield was quantified via ${ }^{1} \mathrm{H}$ NMR. 
Table 1: Variation of hydrocarboxylation reaction conditions. ${ }^{a}$

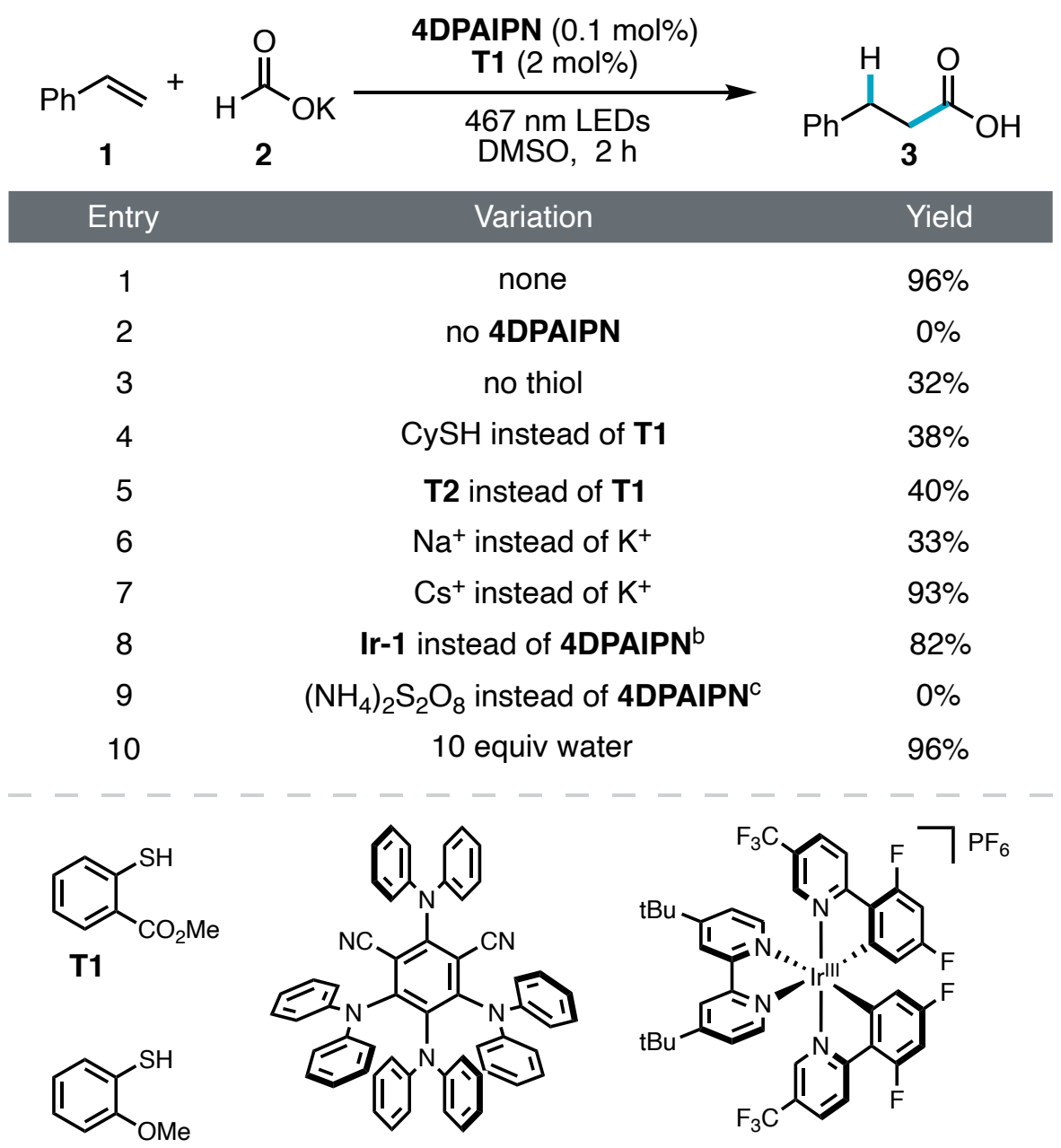

T2

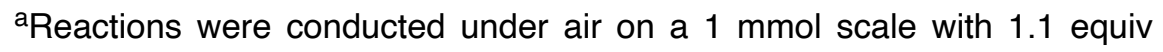
$\mathrm{KCHO}_{2}$. Yield of 3 determined by ${ }^{1} \mathrm{H}$ NMR analysis. See the Supporting Information (SI) for details. ${ }^{b}$ The reaction was run for $24 \mathrm{~h}$ with $1 \mathrm{~mol} \%$ Ir-1. ${ }^{C}$ Reaction was heated to $100^{\circ} \mathrm{C}$.

Entry 1: Following above general procedure

Entry 2: Following above general procedure except without the addition of 4DPAIPN

Entry 3: Following above general procedure except without the addition of methyl thiosalicylate Entry 4: Following above general procedure except Cyclohexanethiol (2.4 $\mu \mathrm{L}, 0.02$ equiv, 20.00 $\mu \mathrm{mol})$

Entry 5: Following above general procedure except 2-methoxybenzenethiol $(2.4 \mu \mathrm{L}, 0.02$ equiv, $20.00 \mu \mathrm{mol})$

Entry 6: Following above general procedure except $\mathrm{NaCHO}_{2}(74.8 \mathrm{mg}, 1.1$ equiv, $1.10 \mathrm{mmol})$ Entry 7: Following above general procedure except $\mathrm{CsCHO}_{2}(215.5 \mathrm{mg}, 1.1$ equiv, $1.10 \mathrm{mmol})$ Entry 8: Following above general procedure except Ir-1 (11.2 mg, 0.01 equiv, $10.00 \mu \mathrm{mol})$ and $24 \mathrm{~h}$ reaction time 
Entry 9: Following above general procedure with the addition of $(180 \mu \mathrm{L}, 10.0$ equiv, 10.0 mmol)

Optimization of tri-substituted acrylates

Table S9. Optimization of more sterically hindered substrates

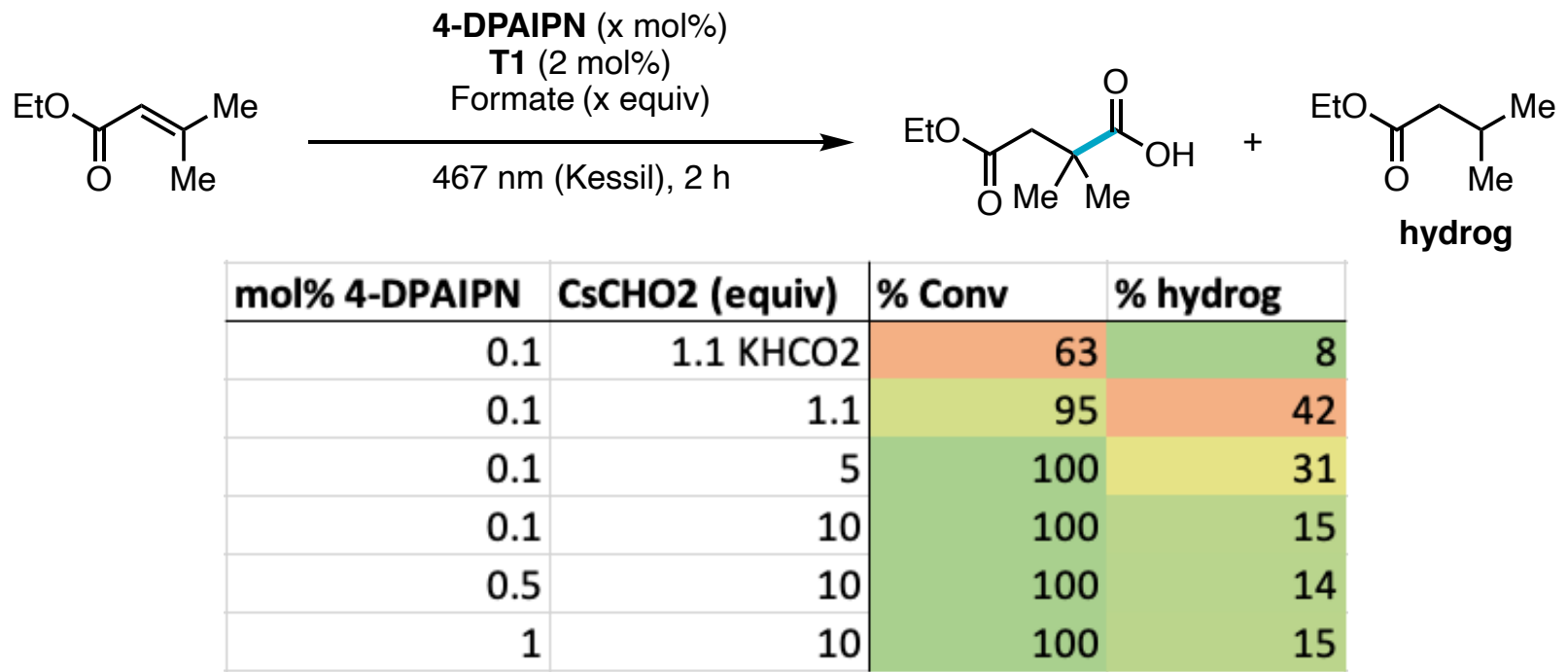

Formate (varying loading and counterion) and 4DPAIPN (varying loading) were added to a $20 \mathrm{~mL}$ scintillation vial (oven-dried, cooled in desiccator). Ethyl 3-methylbut-2-enoate* (139 $\mu \mathrm{L}, 1.00$ equiv, $1.00 \mathrm{mmol})$, methyl thiosalicylate $(2.8 \mu \mathrm{L}, 0.02$ equiv, $20.00 \mu \mathrm{mol})$, and $15 \mathrm{~mL}$ DMSO were added to the vial and capped with a teflon cap. With fan cooling, irradiate with a $467 \mathrm{~nm}$ Kessil lamp for $2 \mathrm{~h}$.

*Filter off the inhibitor by passing through $\sim 1$ in basic alumina immediately prior to use. 
Scheme S7. Unsuccessful substrates

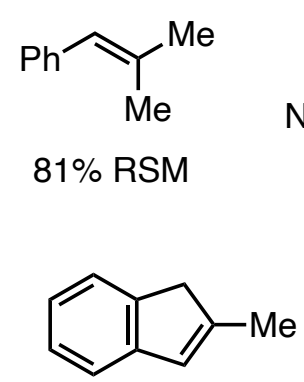

$0 \%$ RSM

$0 \% \mathrm{pdt}$

$\mathrm{Me}$

$0 \%$ pdt<smiles>C=Cc1ccc(C#N)cc1</smiles>

$46 \%(2: 1 \mathrm{l}: b)$

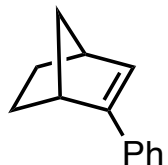

$0 \%$ RSM

$0 \% \mathrm{pdt}$

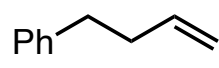

$10 \%$ RSM

$0 \% \mathrm{pdt}$<smiles>C=Cc1ccc(O)cc1</smiles><smiles>C=CC(=O)N(C)C</smiles>

$0 \%$ RSM $<10 \%$ pdt<smiles>C=C(C)CCCCCCC</smiles>

$0 \%$ pdt<smiles>N#C/C=C/c1ccccc1</smiles>

$48 \%$ RSM mixture of pdts<smiles>C=C[N]</smiles>

$10 \%$<smiles>C/C=C\[AsH2]</smiles>

$0 \%$ RSM $<5 \%$ pdt 


\section{Limiting $\mathrm{Na}^{13} \mathrm{CO}_{2} \mathrm{H}$ Reaction Optimization Tables}

General Procedure: Styrene was used as the model substrate to optimize the limiting sodium formate conditions. Sodium formate was used instead of potassium as sodium is the only counterion available for the isotopically labeled formate salts. ${ }^{12} \mathrm{C}$ formate was used in initial optimization. Conversion and ethylbenzene (PhEt) formation were monitored via GC as conversion of styrene was found to track with yield.

Sodium formate $(6.8 \mathrm{mg}, 1.00$ equiv, $0.10 \mathrm{mmol})$ and 4DPAIPN $(0.8 \mathrm{mg}, 0.01$ equiv, $1.00 \mu \mathrm{mol})$ were added to a 1 dram vial (dried in oven, cooled in desiccator). Styrene* $(17.2 \mu \mathrm{L}, 1.50$ equiv, $0.15 \mathrm{mmol})$, methyl thiosalicylate $(0.3 \mu \mathrm{L}, 0.02$ equiv, $2.00 \mu \mathrm{mol})$, dibenzylether $(19.0 \mu \mathrm{L}, 1.00$ equiv, $0.100 \mathrm{mmol}$ ), and $1.5 \mathrm{~mL}$ DMSO were added. With fan cooling, irradiate with $467 \mathrm{~nm}$ Kessil for $24 \mathrm{~h}$.

*Filter off the inhibitor by passing through $\sim 1$ in basic alumina immediately prior to use.

Table S10. Optimization of limiting $\mathrm{NaCHO}_{2}$ conditions

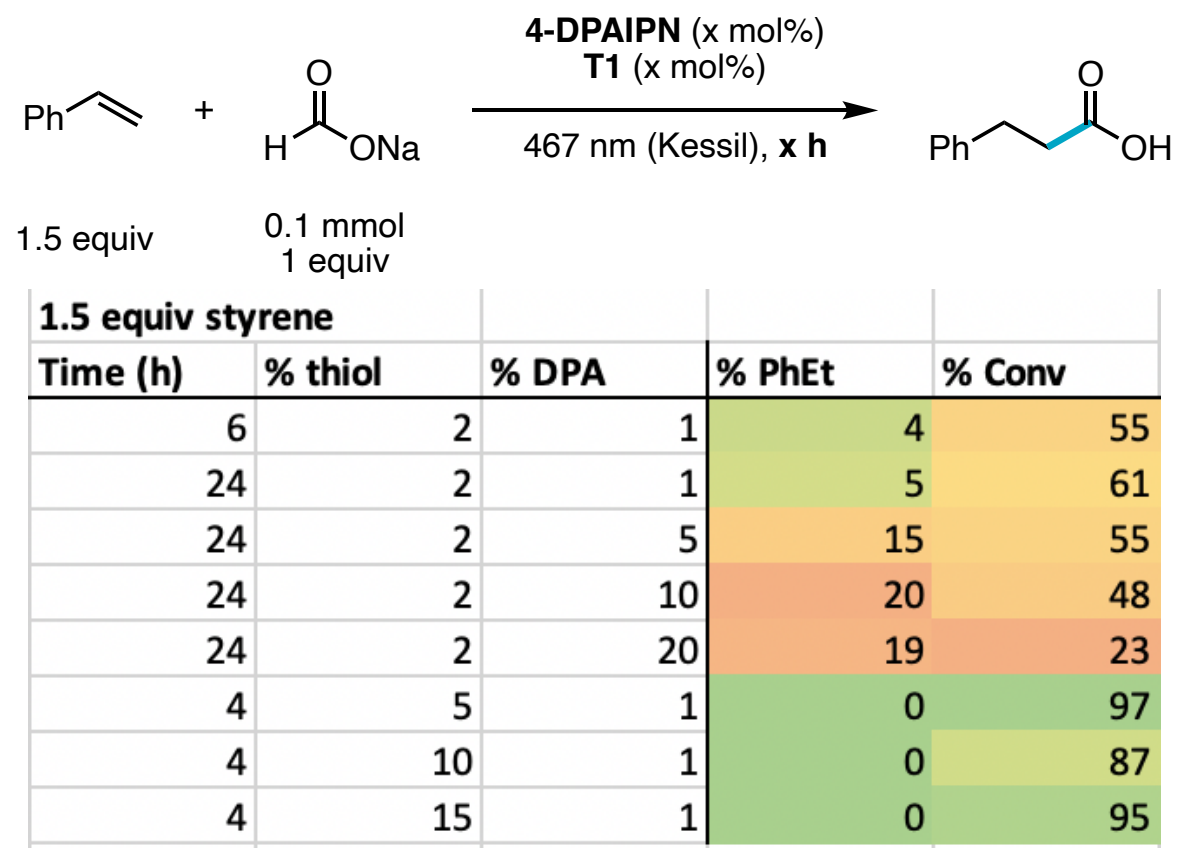

The reactions were run following the above general procedure except varying the thiol loading, 4DPAIPN loading, and time.

Scheme S8. Optimization of limiting $\mathrm{NaCHO}_{2}$ conditions on bioactive molecule

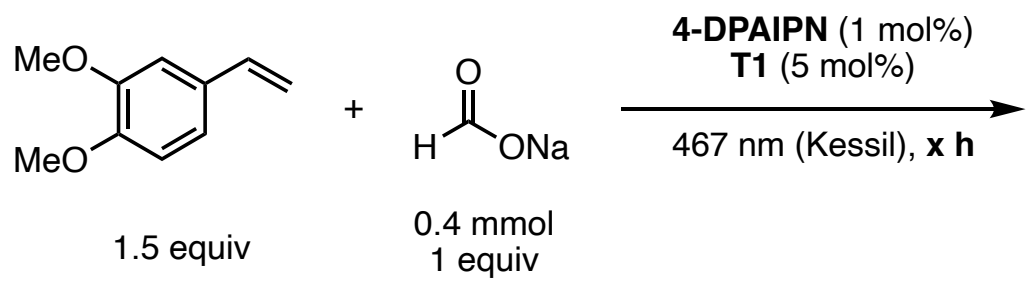<smiles>COc1ccc(CCC(=O)O)cc1OC</smiles>

5 h: $67 \%$ RSM $8 \mathrm{~h}: 5 \%$ RSM, $74 \%$ pdt 
The reactions were run following the above procedure except using 3,4-dimethoxystyrene, methyl thiosalicylate $(2.8 \mu \mathrm{L}, 0.05$ equiv, $20.00 \mu \mathrm{mol})$, and varying time. 


\section{Starting Material and Catalyst Synthesis}

\section{Tert-butyl (4-vinylphenyl)carbamate}<smiles>C=Cc1ccc(NC(=O)OC(C)(C)C)cc1</smiles>

To a solution of 4-vinylaniline $\left(1.2 \mathrm{~mL}, 10.00 \mathrm{mmol}, 1.0\right.$ equiv) in $\mathrm{H}_{2} \mathrm{O}(15 \mathrm{~mL})$ was added ditertbutyl dicarbonate $(3.49 \mathrm{~g}, 16.00 \mathrm{mmol}, 1.6$ equiv) at room temperature. After stirring for $8 \mathrm{~h}$, the crude mixture was extracted with ethyl acetate. The combined organic layers were washed with brine, dried over anhydrous magnesium sulfate, filtered, and concentrated under reduced pressure. The crude mixture was purified by column chromatography to afford $1.64 \mathrm{~g}(7.47 \mathrm{mmol}, 75 \%$ yield). ${ }^{1} \mathbf{H}$ NMR $\left(400 \mathrm{MHz}, \mathrm{CDCl}_{3}\right) \delta 7.28-7.39(\mathrm{~m}, 4 \mathrm{H}), 6.66(\mathrm{dd}, J=17.6,10.9 \mathrm{~Hz}, 1 \mathrm{H}), 6.44$ $-6.49(\mathrm{~s}, 1 \mathrm{H}), 5.65(\mathrm{~d}, J=17.6 \mathrm{~Hz}, 1 \mathrm{H}), 5.12-5.20(\mathrm{~d}, J=10.9 \mathrm{~Hz}, 1 \mathrm{H}), 1.52(\mathrm{~s}, 9 \mathrm{H})$. The ${ }^{1} \mathrm{H}$ NMR spectrum is in agreement with those reported in the literature. ${ }^{2}$

\section{(4-Vinylphenyl)boronic acid pinacol ester}

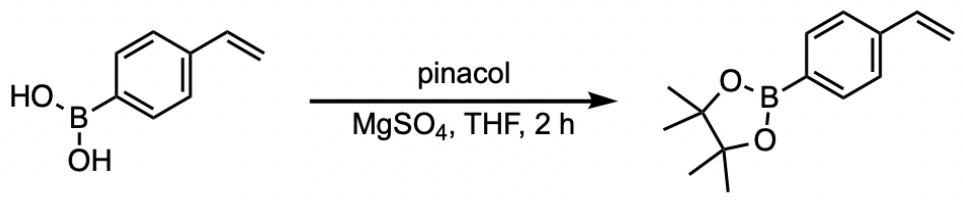

4-vinylphenylboronic acid (1.08 g, $7.3 \mathrm{mmol}, 1.00$ equiv) and pinacol (860 mg, $7.3 \mathrm{mmol}, 1.00$ equiv) were added to a flame-dried flask and purged with $\mathrm{N}_{2}$. THF (37 mL, $\left.0.20 \mathrm{M}\right)$ was added to dissolve the solids, and two spatula tips of MgSO4 were added to the mixture. The reaction was allowed to stir for $2 \mathrm{~h}$ at room temperature, filtered through Celite, and concentrated. The crude mixture was purified by column chromatography to afford $1.35 \mathrm{~g}$ (5.86 mmol, $81 \%$ yield). ${ }^{1} \mathbf{H}$ NMR (400 MHz, $\left.\mathrm{CDCl}_{3}\right) \delta 7.71-7.82(\mathrm{~d}, J=8.1 \mathrm{~Hz}, 2 \mathrm{H}), 7.37-7.44(\mathrm{~d}, J=8.0 \mathrm{~Hz}, 2 \mathrm{H}), 6.73$ (dd, $J=17.6,10.9 \mathrm{~Hz}, 1 \mathrm{H}), 5.81$ (d, $J=17.5 \mathrm{~Hz}, 1 \mathrm{H}), 5.29$ (d, $J=10.9 \mathrm{~Hz}, 1 \mathrm{H}), 1.35$ (s, 12H). The ${ }^{1} \mathrm{H}$ NMR spectrum is in agreement with those reported in the literature. ${ }^{3}$

\section{(4-Vinylphenyl)methanol}

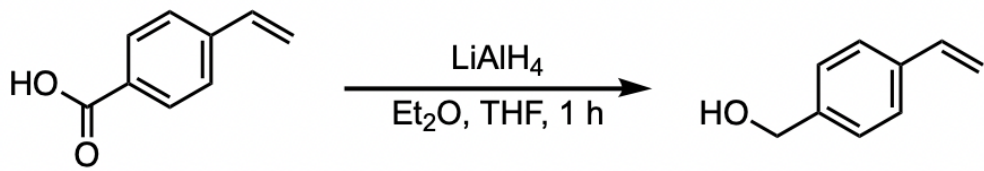

To a $0{ }^{\circ} \mathrm{C}$ slurry of $\mathrm{LiAlH}_{4}(3.36 \mathrm{~g}, 88.50 \mathrm{mmol}, 1.00$ equiv) in THF $356 \mathrm{~mL})$ was added a solution of 4-vinylbenzoic acid (2.22 g, $15.00 \mathrm{mmol}, 5.9$ equiv) in $\mathrm{Et}_{2} \mathrm{O}(112 \mathrm{~mL})$ dropwise. After addition, the reaction mixture was warmed to room temperature and stirred for one hour. The reaction was quenched via the following workup: $1.2 \mathrm{~mL} \mathrm{H}_{2} \mathrm{O}$ added slowly, followed by addition of $2.3 \mathrm{~mL}$ 
10 wt $\% \mathrm{NaOH}$ solution, and then $3.4 \mathrm{~mL} \mathrm{H}_{2} \mathrm{O}$. The reaction was stirred vigorously until a white solid was formed. The reaction mixture was filtered, dried over $\mathrm{MgSO}_{4}$, and concentrated in vacuo. The resulting oil was purified by column chromatography to provide $771 \mathrm{mg}(5.75 \mathrm{mmol}, 38 \%$ yield). ${ }^{1} \mathbf{H}$ NMR (500 MHz, $\left.\mathrm{CDCl}_{3}\right) \delta 7.41(\mathrm{~d}, J=7.9 \mathrm{~Hz}, 2 \mathrm{H}), 7.33(\mathrm{~d}, J=7.9 \mathrm{~Hz}, 2 \mathrm{H}), 6.72$ (dd, $J=17.6,10.9 \mathrm{~Hz}, 1 \mathrm{H}), 5.75(\mathrm{~d}, J=17.5 \mathrm{~Hz}, 1 \mathrm{H}), 5.25$ (d, $J=10.9 \mathrm{~Hz}, 1 \mathrm{H}), 4.69$ (d, $J=4.5 \mathrm{~Hz}$, 2H). The ${ }^{1} \mathrm{H}$ NMR spectrum is in agreement with those reported in the literature. The ${ }^{1} \mathrm{H}$ NMR spectrum is in agreement with those reported in the literature. ${ }^{2}$

\section{(E)-1-((3aR,7aS)-octahydro-2H-isoindol-2-yl)-4-phenylbut-3-en-1-one}

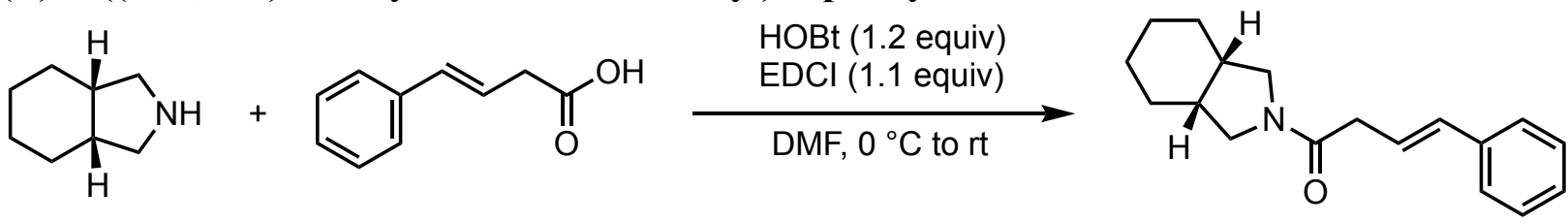

To a solution of styrylacetic acid $(2.43 \mathrm{~g}, 15.00 \mathrm{mmol}, 1.00 \mathrm{equiv})$ and $\mathrm{HOBt}(2.43 \mathrm{~g}, 18.00$ mmmol, 1.20 equiv) in DMF (30 mL) were added EDCI (3.16 g, $16.50 \mathrm{mmol}, 1.10$ equiv) and cisOctahydro-1H-isoindole (1.88 g, $15.00 \mathrm{mmol}, 1.00$ equiv) at $0{ }^{\circ} \mathrm{C}$. The mixture was stirred for 24 hours, and then diluted in $200 \mathrm{~mL}$ EtOAc. The organic phase was washed with water $(2 \times 100 \mathrm{~mL})$, saturated aqueous $\mathrm{NaHCO}_{3}(1 \times 100 \mathrm{~mL}, 2 \times 50 \mathrm{~mL})$, and brine $(50 \mathrm{~mL})$, then dried over $\mathrm{Na}_{2} \mathrm{SO}_{4}$, filtered, and concentrated to give $3.98 \mathrm{~g}\left(14.78 \mathrm{mmol}, 99 \%\right.$ yield). ${ }^{1} \mathbf{H} \mathbf{~ N M R}\left(400 \mathrm{MHz}, \mathrm{CDCl}_{3}\right) \delta$ $7.34-7.42(\mathrm{~m}, 2 \mathrm{H}) 7.25-7.34(\mathrm{~m}, 3 \mathrm{H}), 7.16-7.25(\mathrm{~m}, 1 \mathrm{H}), 6.43-6.55(\mathrm{~d}, J=15.9 \mathrm{~Hz}, 1 \mathrm{H})$, $6.37(\mathrm{dt}, J=15.9,6.6 \mathrm{~Hz}, 1 \mathrm{H}), 3.29-3.58(\mathrm{~m}, 4 \mathrm{H}), 3.24(\mathrm{~d}, J=6.6 \mathrm{~Hz}, 2 \mathrm{H}), 2.36-2.14(\mathrm{~m}, 2 \mathrm{H})$, $1.25-1.71(\mathrm{~m}, 8 \mathrm{H}) .{ }^{13} \mathbf{C}$ NMR $\left(126 \mathrm{MHz}, \mathrm{CDCl}_{3}\right) \delta 170.07,137.14,132.59,128.50,127.34$, $126.25,123.27,50.84,49.63,39.28,37.71,35.95,25.81,25.75,22.83,22.57$. HRMS $(\mathrm{m} / z)[\mathrm{M}+$ $\mathrm{H}]$ - calcd for C18H24NO, 270.1852; found, 270.1849.

\section{2,4,5,6-tetrakis(diphenylamino)isophthalonitrile (4DPAIPN)}
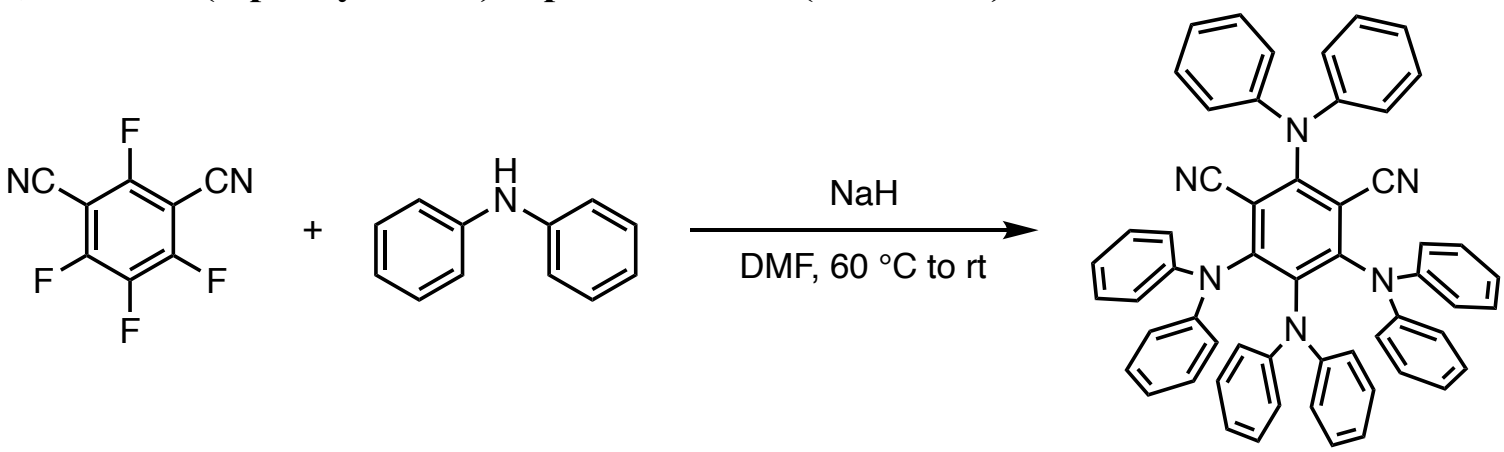

$\mathrm{NaH}$ (60\% dispersion, $3.00 \mathrm{~g}, 75.0 \mathrm{mmol}, 7$ equiv) was added to a flame-dried flask under N2. DMF $(150 \mathrm{~mL})$ was then added followed by slow addition of a solution of diphenylamine $(8.46 \mathrm{~g}$, $50.00 \mathrm{mmol}, 5.00$ equiv) in DMF $(25 \mathrm{~mL})$. The mixture was then heated to $60{ }^{\circ} \mathrm{C}$ for $30 \mathrm{~min}$. 2,4,5,6-tetrafluoroisophthalonitrile (2.00 g, $10.0 \mathrm{mmol}, 1.00$ equiv) in DMF $(25 \mathrm{~mL})$ was then slowly added. The solution was allowed to stir at $40{ }^{\circ} \mathrm{C}$ for $12 \mathrm{~h}$ and $\mathrm{rt}$ for an additional $12 \mathrm{~h}$.

The reaction mixture was then cooled in an ice bath and $10 \mathrm{~mL}$ water was added slowly to quench residual $\mathrm{NaH}$. The quenched mixture was then added to a flask containing $200 \mathrm{~mL}$ water. The precipitate was filtered off and concentrated. After redissolving in DCM, the product was filtered through a silica plug and then recrystallized from DCM/hexanes affording $4.92 \mathrm{~g}(6.17 \mathrm{mmol}, 62 \%$ yield). ${ }^{1} \mathrm{H}$ NMR (400 MHz, $\left.\mathrm{CDCl}_{3}\right) \delta$ 7.25-7.29 (m, 4H), 6.98 - 7.12 (m, 14H), 6.89 (dt, $J=13.4$, 
$7.8 \mathrm{~Hz}, 8 \mathrm{H}), 6.66-6.73(\mathrm{~m}, 10 \mathrm{H}), 6.55(\mathrm{~d}, J=7.9 \mathrm{~Hz}, 4 \mathrm{H})$. The ${ }^{1} \mathrm{H}$ NMR spectrum is in agreement with those reported in the literature. ${ }^{4}$ 


\section{General Experimental Procedures}

\section{General Procedure A - Standard Conditions}

Potassium formate $(92.5 \mathrm{mg}, 1.1$ equiv, $1.10 \mathrm{mmol})$ and 4DPAIPN ( $0.8 \mathrm{mg}, 0.001$ equiv, 1.00 $\mu \mathrm{mol})$ were added to a $20 \mathrm{~mL}$ scintillation vial (oven-dried, cooled in desiccator). Alkene* (1 equiv, $1.00 \mathrm{mmol})$, methyl thiosalicylate $(2.8 \mu \mathrm{L}, 0.02$ equiv, $20.00 \mu \mathrm{mol})$, and $15 \mathrm{~mL}$ of DMSO were added to the vial and capped with a teflon cap. With fan cooling, irradiate with a $467 \mathrm{~nm}$ Kessil lamp for $2 \mathrm{~h}$.

*If alkene has an inhibitor present, filter off the inhibitor by passing through $\sim 1$ in basic alumina immediately prior to use.

\section{General Procedure B - Forcing Conditions}

Cesium formate $(1.959 \mathrm{~g}, 10$ equiv, $10.00 \mathrm{mmol})$ and 4DPAIPN (8.0 mg, 0.01 equiv, $10.00 \mu \mathrm{mol})$ were added to a $20 \mathrm{~mL}$ scintillation vial (oven-dried, cooled in desiccator). Alkene* (1 equiv, 1.00 mmol), methyl thiosalicylate $(2.8 \mu \mathrm{L}, 0.02$ equiv, $20.00 \mu \mathrm{mol})$, and $15 \mathrm{~mL}$ of DMSO were added to the vial and capped with a teflon cap. With fan cooling, irradiate with a $467 \mathrm{~nm}$ Kessil lamp for $2 \mathrm{~h}$.

*If alkene has an inhibitor present, filter off the inhibitor by passing through $\sim 1$ in basic alumina immediately prior to use.

\section{General Procedure C - Run in $\mathbf{d}^{6}$-DMSO}

Potassium formate $(92.5 \mathrm{mg}, 1.1$ equiv, $1.10 \mathrm{mmol})$ and 4DPAIPN (0.8 mg, 0.001 equiv, 1.00 $\mu \mathrm{mol})$ were added to a $20 \mathrm{~mL}$ scintillation vial (oven-dried, cooled in desiccator). Alkene* (1 equiv, $1.00 \mathrm{mmol})$, methyl thiosalicylate $(2.8 \mu \mathrm{L}, 0.02$ equiv, $20.00 \mu \mathrm{mol})$, and $15 \mathrm{~mL}$ of $\mathrm{d}^{6}$-DMSO were added to the vial and capped with a teflon cap. With fan cooling, irradiate with a $467 \mathrm{~nm}$ Kessil lamp for $5 \mathrm{~h}$.

The reaction was acidified using TFA until $\mathrm{pH}=1 . \mathrm{CH}_{2} \mathrm{Br}_{2}(70 \mathrm{uL}, 1.00$ equiv, $1.00 \mathrm{mmol})$ was added as an internal standard and the yield was quantified via ${ }^{1} \mathrm{H}$ NMR.

*If alkene has an inhibitor present, filter off the inhibitor by passing through $\sim 1$ in basic alumina immediately prior to use.

For GC analysis: Add dibenzylether (190 $\mu \mathrm{L}, 1.00 \mathrm{mmol}, 1.00$ equiv) to crude reaction and remove a $0.2 \mathrm{~mL}$ aliquot. Dilute aliquot with $1 \mathrm{~mL}$ diethyl ether, extract with $1 \mathrm{~mL}$ brine, and pass through $\sim 1$ in silica.

Note: By our GC-FID, the product is not visible so the residual starting material was monitored.

For NMR yield: Reaction mixture was transferred to a $500 \mathrm{~mL}$ sep funnel with $2 \times 2 \mathrm{~mL}$ EtOAc, $2 \times 2 \mathrm{~mL} \mathrm{10 \%} \mathrm{HCl} 20 \%$ brine aq solution, $2 \times 2 \mathrm{~mL}$ EtOAc. $250 \mathrm{~mL} \mathrm{10 \%} \mathrm{HCl} 20 \%$ brine aq solution was added and the mixture was extracted 3x100 mL EtOAc. Combined organic layers were washed with $3 \times 75 \mathrm{~mL} \mathrm{NaHCO}_{3}$ (collected in a separate flask from brine aq layer). The neutralized aq layer 
was acidified with conc $\mathrm{HCl}$ until $\mathrm{pH}=1$ (bright pink on $\mathrm{pH}$ paper). The aq was then extracted $1 \times 100 \mathrm{~mL}$ and $3 \times 50 \mathrm{~mL}$ EtOAc. Combined organic layers were dried over $\mathrm{Na}_{2} \mathrm{SO}_{4}$ and $\mathrm{MgSO}_{4}$ and concentrated. $\mathrm{CH}_{2} \mathrm{Br}_{2}(70 \mathrm{uL}, 1.0$ equiv, $1.00 \mathrm{mmol})$ was added as an internal standard and the yield was quantified via ${ }^{1} \mathrm{H} \mathrm{NMR}$.

For product isolation: Reaction mixture was transferred to a $500 \mathrm{~mL}$ sep funnel with $2 \times 2 \mathrm{~mL}$ EtOAc, $2 \times 2 \mathrm{~mL} \mathrm{10 \%} \mathrm{HCl} \mathrm{20 \%} \mathrm{brine} \mathrm{aq} \mathrm{solution,} 2 \times 2 \mathrm{~mL}$ EtOAc. $250 \mathrm{~mL} \mathrm{10 \%} \mathrm{HCl} 20 \%$ brine aq solution was added and the mixture was extracted 3x100 mL EtOAc. Combined organic layers were washed with brine, dried over $\mathrm{Na}_{2} \mathrm{SO}_{4}$ and $\mathrm{MgSO}_{4}$, and concentrated. The product was then purified via column chromatography (gradient of EtOAc and 1\% $\mathrm{AcOH}$ in hexanes). To remove residual $\mathrm{AcOH}$ after purification, the product was azeotroped with benzene.

For product isolation of Boc containing compounds: Reaction mixture was acidified using conc. $\mathrm{HCl}$ until $\mathrm{pH}=4$ and then transferred to a $500 \mathrm{~mL}$ sep funnel with $2 \times 2 \mathrm{~mL}$ EtOAc, $2 \times 2 \mathrm{~mL}$ water, $2 \times 2 \mathrm{~mL}$ EtOAc. $250 \mathrm{~mL} \mathrm{20 \%}$ brine aq solution was added and the mixture was extracted $3 \times 100$ $\mathrm{mL}$ EtOAc. Combined organic layers were washed with brine, dried over $\mathrm{Na}_{2} \mathrm{SO}_{4}$ and $\mathrm{MgSO}_{4}$, and concentrated. The product was then purified via column chromatography (gradient of EtOAc and $1 \% \mathrm{AcOH}$ in hexanes). To remove residual $\mathrm{AcOH}$ after purification, the product was azeotroped with benzene.

\section{Preparation of re-packed columns:}

$50 \mathrm{~g}$ of silica is suspended in 5\% EtoAc/Hexanes and poured into an empty $50 \mathrm{~g}$ column. Silica pad is settled with slight pressure and a frit is added. The cartridge is then pounded with a Teflon rod and equilibrated with $7 \%$ EtoAc/Hexanes $(1 \% \mathrm{AcOH})(175 \mathrm{~mL})$ at $75 \mathrm{~mL} / \mathrm{min}$. 


\section{Product Isolation and Characterization}<smiles>O=C(O)CCc1ccccc1</smiles>

\section{Hydrocinnamic acid (3)}

General Procedure A was followed using styrene to afford $\mathbf{3}$ in 80\% yield (120.0 $\mathrm{mg}, 0.80$ mmol). ${ }^{1} \mathbf{H}$ NMR $\left(500 \mathrm{MHz}, \mathrm{CDCl}_{3}\right) \delta 7.35-7.28(\mathrm{~m}, 2 \mathrm{H}), 7.25-7.19(\mathrm{~m}, 3 \mathrm{H}), 2.97$ (t, $J=7.8$ $\mathrm{Hz}, 2 \mathrm{H}), 2.70(\mathrm{t}, J=7.8 \mathrm{~Hz}, 2 \mathrm{H})$. The ${ }^{1} \mathrm{H}$ NMR spectrum is in agreement with those reported in the literature. ${ }^{2}$<smiles>COc1ccc(CCC(=O)O)cc1</smiles>

\section{3-(4-methoxyphenyl)propanoic acid (4)}

General Procedure A was followed using 4-vinylanisole to afford 4 in $83 \%$ yield (149.4 mg, 0.83 mmol). ${ }^{1} \mathbf{H}$ NMR (500 MHz, $\left.\mathrm{CDCl}_{3}\right) \delta 7.13(\mathrm{~d}, J=8.7 \mathrm{~Hz}, 2 \mathrm{H}), 6.85(\mathrm{~d}, J=8.7 \mathrm{~Hz}, 2 \mathrm{H}), 3.79$ (s, $3 \mathrm{H}), 2.90(\mathrm{t}, J=7.7 \mathrm{~Hz}, 2 \mathrm{H}), 2.65(\mathrm{t}, J=7.7 \mathrm{~Hz}, 2 \mathrm{H})$. The ${ }^{1} \mathrm{H}$ NMR spectrum is in agreement with those reported in the literature. ${ }^{2}$<smiles>O=C(O)CCc1ccc(NC(=O)c2ccccc2)cc1</smiles>

\section{3-(4-((tert-butoxycarbonyl)amino)phenyl)propanoic acid (5)}

General Procedure A was followed using tert-butyl (4-vinylphenyl)carbamate to afford 5 in $77 \%$ yield (204.3 mg, $0.77 \mathrm{mmol}) .{ }^{1} \mathbf{H}$ NMR $\left(500 \mathrm{MHz}, \mathrm{CDCl}_{3}\right) \delta 7.32-7.23(\mathrm{~m}, 2 \mathrm{H}), 7.14(\mathrm{~d}, J=8.5$ $\mathrm{Hz}, 2 \mathrm{H}), 2.90(\mathrm{t}, J=7.7 \mathrm{~Hz}, 2 \mathrm{H}), 2.64(\mathrm{t}, J=7.7 \mathrm{~Hz}, 2 \mathrm{H}), 1.51(\mathrm{~s}, 9 \mathrm{H})$. The ${ }^{1} \mathrm{H}$ NMR spectrum is in agreement with those reported in the literature. ${ }^{2}$<smiles>O=C(O)CCc1ccc(Cl)cc1</smiles>

\section{3-(4-chlorophenyl)propanoic acid (6)}

General Procedure A was followed using 4-chlorostyrene to afford 6 in $74 \%$ yield $(136.0 \mathrm{mg}$, $0.74 \mathrm{mmol}) .{ }^{1} \mathbf{H}$ NMR $\left(500 \mathrm{MHz}, \mathrm{CDCl}_{3}\right) \delta 7.29-7.24(\mathrm{~m}, 3 \mathrm{H}), 7.18-7.12(\mathrm{~m}, 2 \mathrm{H}), 2.92(\mathrm{t}, J=$ $7.7 \mathrm{~Hz}, 2 \mathrm{H}), 2.67(\mathrm{t}, J=7.7 \mathrm{~Hz}, 2 \mathrm{H})$. The ${ }^{1} \mathrm{H}$ NMR spectrum is in agreement with those reported in the literature. ${ }^{5}$ 
<smiles>O=C(O)CCc1ccc(C(=O)O)cc1</smiles>

\section{3-(4-Carboxyphenyl)propionic Acid (7)}

General Procedure A was followed using 4-vinylbenzoic acid but using cesium formate (1.959 g, 10 equiv, $10.00 \mathrm{mmol}$ ) instead of 1 equiv of potassium formate due to similar pKas of the starting material and formate. 7 was afforded in $74 \%$ yield $(0.74 \mathrm{mmol})$, analyzed by ${ }^{1} \mathrm{H}$ NMR. ${ }^{1}$ H NMR (400 MHz, DMSO) $\delta 7.85(\mathrm{~d}, J=8.2 \mathrm{~Hz}, 2 \mathrm{H}), 7.35(\mathrm{~d}, J=8.3 \mathrm{~Hz}, 2 \mathrm{H}), 2.88(\mathrm{t}, J=7.6$ $\mathrm{Hz}, 2 \mathrm{H}), 2.57(\mathrm{t}, J=7.6 \mathrm{~Hz}, 2 \mathrm{H})$. The ${ }^{1} \mathrm{H}$ NMR spectrum is in agreement with those reported in the literature. ${ }^{6}$<smiles>CC1(C)OB(c2ccc(CCC(=O)O)cc2)OC1(C)C</smiles>

\section{3-(4-(4,4,5,5-tetramethyl-1,3,2-dioxaborolan-2-yl)phenyl)propanoic acid (8)}

General Procedure A was followed using 4,4,5,5-tetramethyl-2-(4-vinylphenyl)-1,3,2dioxaborolane to afford 8 in $67 \%$ yield $(184.9 \mathrm{mg}, 0.67 \mathrm{mmol}) .{ }^{1} \mathbf{H} \mathbf{~ N M R}\left(500 \mathrm{MHz}, \mathrm{CDCl}_{3}\right) \delta$ $7.75(\mathrm{~d}, J=7.9 \mathrm{~Hz}, 2 \mathrm{H}), 7.23(\mathrm{~d}, J=7.9 \mathrm{~Hz}, 2 \mathrm{H}), 2.97$ (t, $J=7.8 \mathrm{~Hz}, 2 \mathrm{H}), 2.69(\mathrm{t}, J=7.8 \mathrm{~Hz}$, $2 \mathrm{H}), 1.33(\mathrm{~s}, 12 \mathrm{H})$. The ${ }^{1} \mathrm{H}$ NMR spectrum is in agreement with those reported in the literature. ${ }^{7}$<smiles>O=C(O)CCc1ccc(CO)cc1</smiles>

\section{3-(4-(hydroxymethyl)phenyl)propanoic acid (9)}

General Procedure A was followed using (4-vinylphenyl)methanol to afford 9 in $75 \%$ yield (132.5 mg, $0.75 \mathrm{mmol}){ }^{1}{ }^{1} \mathrm{H}$ NMR (400 MHz, DMSO) $\delta 12.09$ (s, 1H), $7.22(\mathrm{~d}, J=8.1 \mathrm{~Hz}, 2 \mathrm{H})$, $7.17(\mathrm{~d}, J=8.1 \mathrm{~Hz}, 2 \mathrm{H}), 5.10(\mathrm{~s}, 1 \mathrm{H}), 4.45(\mathrm{~s}, 2 \mathrm{H}), 2.80$ (t, $J=7.6 \mathrm{~Hz}, 2 \mathrm{H}), 2.62-2.40(\mathrm{~m}, 3 \mathrm{H})$. The ${ }^{1} \mathrm{H}$ NMR spectrum is in agreement with those reported in the literature. ${ }^{2}$<smiles>O=C(O)CCc1ccccn1</smiles>

\section{2-(2-carboxyethyl)pyridin-1-ium (10)}

General Procedure $\mathrm{C}$ was followed using 2-vinylpyridine to afford 10 in $79 \%$ yield $(0.79 \mathrm{mmol})$, analyzed by ${ }^{1} \mathrm{H}$ NMR. ${ }^{1} \mathbf{H}$ NMR $(400 \mathrm{MHz}, \mathrm{DMSO}) \delta 8.83(\mathrm{dd}, J=5.8,1.6 \mathrm{~Hz}, 1 \mathrm{H}), 8.52(\mathrm{dd}, J$ $=8.9,7.0 \mathrm{~Hz}, 1 \mathrm{H}), 8.01(\mathrm{~d}, J=8.2 \mathrm{~Hz}, 1 \mathrm{H}), 3.21(\mathrm{t}, J=7.2 \mathrm{~Hz}, 2 \mathrm{H}), 2.83(\mathrm{t}, J=7.3 \mathrm{~Hz}, 2 \mathrm{H})$. The ${ }^{1} \mathrm{H}$ NMR spectrum is in agreement with those reported in the literature. ${ }^{8}$ 
<smiles>CC(CC(=O)O)c1ccccc1</smiles>

\section{3-phenylbutanoic acid (11)}

General Procedure A was followed using $\alpha$-methylstyrene to afford $\mathbf{1 1}$ in 84\% yield (137.4 mg, $0.84 \mathrm{mmol}) .{ }^{1} \mathbf{H}$ NMR $\left(500 \mathrm{MHz}, \mathrm{CDCl}_{3}\right) \delta$ 7.36-7.28 (m, 2H), $7.25-7.18(\mathrm{~m}, 3 \mathrm{H}), 3.27$ (dt, $J=$ $8.1,6.8 \mathrm{~Hz}, 1 \mathrm{H}), 2.68(\mathrm{dd}, J=15.5,6.8 \mathrm{~Hz}, 1 \mathrm{H}), 2.58(\mathrm{dd}, J=15.6,8.2 \mathrm{~Hz}, 1 \mathrm{H}), 1.32(\mathrm{~d}, J=7.0$ $\mathrm{Hz}, 3 \mathrm{H})$. The ${ }^{1} \mathrm{H}$ NMR spectrum is in agreement with those reported in the literature. ${ }^{2}$<smiles>CC(Cc1ccccc1)C(=O)O</smiles>

\section{2-methyl-3-phenylpropanoic acid (12)}

General Procedure A was followed using cis- $\beta$-methylstyrene to afford $\mathbf{1 2}$ in $83 \%$ yield (136.6 mg, $0.83 \mathrm{mmol}) .{ }^{1} \mathbf{H}$ NMR $\left(500 \mathrm{MHz}, \mathrm{CDCl}_{3}\right) \delta 7.32-7.27(\mathrm{~m}, 2 \mathrm{H}), 7.25-7.16(\mathrm{~m}, 3 \mathrm{H}), 3.08$ $(\mathrm{dd}, J=13.5,6.4 \mathrm{~Hz}, 1 \mathrm{H}), 2.84-2.71(\mathrm{~m}, 1 \mathrm{H}), 2.67(\mathrm{dd}, J=13.4,8.0 \mathrm{~Hz}, 1 \mathrm{H}), 1.18(\mathrm{~d}, J=6.9$ $\mathrm{Hz}, 3 \mathrm{H})$. The ${ }^{1} \mathrm{H}$ NMR spectrum is in agreement with those reported in the literature. ${ }^{2}$<smiles>CC(Cc1ccccc1)C(=O)O</smiles>

\section{2-methyl-3-phenylpropanoic acid (12)}

General Procedure A was followed using trans- $\beta$-methylstyrene to afford 12 in 80\% yield (131.4 mg, $0.80 \mathrm{mmol}) .{ }^{1} \mathbf{H}$ NMR $\left(500 \mathrm{MHz}, \mathrm{CDCl}_{3}\right) \delta 7.32-7.27(\mathrm{~m}, 2 \mathrm{H}), 7.25-7.16(\mathrm{~m}, 3 \mathrm{H}), 3.08$ $(\mathrm{dd}, J=13.5,6.4 \mathrm{~Hz}, 1 \mathrm{H}), 2.84-2.71(\mathrm{~m}, 1 \mathrm{H}), 2.67(\mathrm{dd}, J=13.4,8.0 \mathrm{~Hz}, 1 \mathrm{H}), 1.18(\mathrm{~d}, J=6.9$ $\mathrm{Hz}, 3 \mathrm{H})$. The ${ }^{1} \mathrm{H}$ NMR spectrum is in agreement with those reported in the literature. ${ }^{2}$<smiles>O=C(O)C(CO)Cc1ccccc1</smiles>

\section{2-benzyl-3-hydroxypropanoic acid (13)}

General Procedure A was followed using cinnamyl alcohol to afford $\mathbf{1 3}$ in $71 \%$ yield (128.0 mg, $0.71 \mathrm{mmol}) .{ }^{1} \mathbf{H}$ NMR $\left(500 \mathrm{MHz}, \mathrm{CDCl}_{3}\right) \delta$ 7.33-7.27 (m, 2H), 7.25-7.17 (m, 3H), 3.84 - 3.76 $(\mathrm{m}, 1 \mathrm{H}), 3.76-3.69(\mathrm{~m}, 1 \mathrm{H}), 3.14-3.05(\mathrm{~m}, 1 \mathrm{H}), 2.95-2.84(\mathrm{~m}, 2 \mathrm{H}), 2.17(\mathrm{~s}, 3 \mathrm{H})$. The ${ }^{1} \mathrm{H}$ NMR spectrum is in agreement with those reported in the literature. ${ }^{2}$ 
<smiles>O=C(O)CC(Cc1ccccc1)C(=O)O</smiles>

\section{2-benzylsuccinic acid (14)}

General Procedure A was followed using trans-styrylacetic acid but using cesium formate (1.959 $\mathrm{g}, 10$ equiv, $10.00 \mathrm{mmol}$ ) instead of 1 equiv of potassium formate due to similar pKas of the starting material and formate. 14 was afforded in $76 \%$ yield $(0.76 \mathrm{mmol})$, analyzed by ${ }^{1} \mathrm{H} \mathrm{NMR}$. ${ }^{1}$ H NMR (400 MHz, DMSO) $\delta 7.36$ - 7.14 (m, 5H), 2.89 (m, 2H), 2.80 - 2.67 (m, 1H), 2.42 (dd, $J=16.8,8.6 \mathrm{~Hz}, 1 \mathrm{H}), 2.24(\mathrm{dd}, J=16.9,4.3 \mathrm{~Hz}, 1 \mathrm{H})$. The ${ }^{1} \mathrm{H}$ NMR spectrum is in agreement with those reported in the literature. ${ }^{9}$<smiles>CC(C)(C)OC(=O)CCC(=O)O</smiles>

\section{4-(tert-butoxy)-4-oxobutanoic acid (15)}

General Procedure A was followed using tert-butyl acrylate to afford $\mathbf{1 5}$ in $65 \%$ yield (113.6 mg, $0.65 \mathrm{mmol}) .{ }^{1} \mathbf{H}$ NMR $\left(400 \mathrm{MHz}, \mathrm{CDCl}_{3}\right) \delta 2.63(\mathrm{dd}, J=7.3,6.0 \mathrm{~Hz}, 2 \mathrm{H}), 2.54(\mathrm{dd}, J=7.4,6.0$ $\mathrm{Hz}, 2 \mathrm{H}), 1.44(\mathrm{~s}, 9 \mathrm{H})$. The ${ }^{1} \mathrm{H}$ NMR spectrum is in agreement with those reported in the literature. ${ }^{10}$<smiles>CCOC(=O)C(C)CC(=O)O</smiles>

\section{4-(ethoxy)-3-methyl-4-oxobutanoic acid (16)}

General Procedure A was followed using ethyl methacrylate to afford 16 in 83\% yield (132.9 $\mathrm{mg}, 0.83 \mathrm{mmol}) .{ }^{1} \mathbf{H} \mathbf{N M R}\left(500 \mathrm{MHz}, \mathrm{CDCl}_{3}\right) \delta 4.15(\mathrm{q}, J=7.1 \mathrm{~Hz}, 2 \mathrm{H}), 2.93-2.84(\mathrm{~m}, 1 \mathrm{H})$, $2.79(\mathrm{dd}, J=16.7,8.1 \mathrm{~Hz}, 1 \mathrm{H}), 2.45(\mathrm{dd}, J=16.7,5.8 \mathrm{~Hz}, 1 \mathrm{H}), 1.35-1.20(\mathrm{~m}, 6 \mathrm{H})$. The ${ }^{1} \mathrm{H}$ NMR spectrum is in agreement with those reported in the literature. ${ }^{11}$<smiles>CCOC(=O)CC(C)C(=O)O</smiles>

\section{4-ethoxy-2-methyl-4-oxobutanoic acid (17)}

General Procedure A was followed using ethyl crotonate to afford 17 in 69\% yield $(111.0 \mathrm{mg}$, $0.69 \mathrm{mmol}) .{ }^{1} \mathbf{H}$ NMR $\left(500 \mathrm{MHz}, \mathrm{CDCl}_{3}\right) \delta 4.15(\mathrm{q}, J=7.1 \mathrm{~Hz}, 2 \mathrm{H}), 2.96(\mathrm{td}, J=7.6,6.1 \mathrm{~Hz}$, $1 \mathrm{H}), 2.73(\mathrm{dd}, J=16.7,8.0 \mathrm{~Hz}, 1 \mathrm{H}), 2.43(\mathrm{dd}, J=16.6,6.0 \mathrm{~Hz}, 1 \mathrm{H}), 1.26(\mathrm{t}, J=7.4 \mathrm{~Hz}, 6 \mathrm{H})$. The ${ }^{1} \mathrm{H}$ NMR spectrum is in agreement with those reported in the literature. ${ }^{12}$ 
<smiles>CCOC(=O)CC(C)(C)C(=O)O</smiles>

\section{4-ethoxy-2,2-dimethyl-4-oxobutanoic acid (18)}

General Procedure B was followed using ethyl crotonate to afford 18 in $73 \%$ yield 6:1

linear:branched isomer (127.2 mg, $0.73 \mathrm{mmol})$. Linear: ${ }^{1} \mathbf{H} \mathbf{N M R}\left(400 \mathrm{MHz}, \mathrm{CDCl}_{3}\right) \delta 4.13(\mathrm{q}, J$ $=7.1 \mathrm{~Hz}, 2 \mathrm{H}), 2.60(\mathrm{~s}, 2 \mathrm{H}), 1.30(\mathrm{~s}, 6 \mathrm{H}), 1.24(\mathrm{t}, J=7.1 \mathrm{~Hz}, 3 \mathrm{H})$. Branched: ${ }^{1} \mathbf{H}$ NMR (400 $\left.\mathrm{MHz}, \mathrm{CDCl}_{3}\right) \delta 4.23(\mathrm{dd}, J=7.2,1.0 \mathrm{~Hz}, 2 \mathrm{H}), 3.18(\mathrm{~d}, J=8.0 \mathrm{~Hz}, 1 \mathrm{H}), 2.48-2.34(\mathrm{~m}, 1 \mathrm{H})$, 1.34-1.27 (m, 3H) $1.05(\mathrm{dd}, J=8.1,6.8 \mathrm{~Hz}, 6 \mathrm{H}) .{ }^{13} \mathbf{C}$ NMR $(126 \mathrm{MHz}, \mathrm{CDCl} 3) \delta 182.10$, 171.16, 60.51, 44.11, 40.40, 25.21, 14.07. HRMS $(\mathrm{m} / \mathrm{z})[\mathrm{M}-\mathrm{H}]-$ calcd for C8H14O4, 173.08193; found, 173.0817.<smiles>CCOC(=O)CC1(C(=O)O)CCOCC1</smiles>

\section{4-(2-ethoxy-2-oxoethyl)tetrahydro-2H-pyran-4-carboxylic acid (19)}

General Procedure B was followed using ethyl(tetrahydropyran-4-ylidene)acetate to afford 19 in 64\% yield 5:1 linear:branched isomer $(138.0 \mathrm{mg}, 0.64 \mathrm{mmol})$. Linear: ${ }^{1} \mathbf{H}$ NMR (400 MHz, $\left.\mathrm{CDCl}_{3}\right) \delta 4.13(\mathrm{q}, J=7.1 \mathrm{~Hz}, 2 \mathrm{H}), 3.79(\mathrm{dt}, J=12.0,4.4 \mathrm{~Hz}, 2 \mathrm{H}), 3.72-3.68(\mathrm{~m}, 2 \mathrm{H}), 2.68(\mathrm{~s}$, 2H), $2.11(\mathrm{~s}, 2 \mathrm{H}), 1.65(\mathrm{ddd}, J=13.9,9.7,4.3 \mathrm{~Hz}, 2 \mathrm{H}), 1.24(\mathrm{t}, J=7.1 \mathrm{~Hz}, 3 \mathrm{H})$. Branched: ${ }^{1} \mathbf{H}$ NMR $\left(400 \mathrm{MHz}, \mathrm{CDCl}_{3}\right) \delta 4.23(\mathrm{q}, J=7.1 \mathrm{~Hz}, 2 \mathrm{H}), 3.98(\mathrm{dd}, J=11.5,4.2 \mathrm{~Hz}, 2 \mathrm{H}), 3.42(\mathrm{tt}, J=$ $11.8,1.8 \mathrm{~Hz}, 2 \mathrm{H}), 3.24(\mathrm{~d}, J=8.6 \mathrm{~Hz}, 1 \mathrm{H}), 2.40-2.24(\mathrm{~m}, 1 \mathrm{H}), 1.65$ (ddd, $J=13.9,9.9,4.2 \mathrm{~Hz}$, $2 \mathrm{H}), 1.57-1.41(\mathrm{~m}, 2 \mathrm{H}), 1.30(\mathrm{t}, J=7.1 \mathrm{~Hz}, 3 \mathrm{H})$. Linear: ${ }^{13} \mathbf{C ~ N M R}\left(126 \mathrm{MHz}, \mathrm{CDCl}_{3}\right) \delta$ 180.12, 170.34, 64.46, 60.81, 43.59, 42.37, 33.50, 14.08. Branched: ${ }^{13} \mathrm{C}$ NMR $(126 \mathrm{MHz}$, $\left.\mathrm{CDCl}_{3}\right) \delta 171.79,168.85,67.55(\mathrm{~d}, J=3.1 \mathrm{~Hz}), 61.85,37.39,30.57,30.38,29.21$. HRMS $(\mathrm{m} / \mathrm{z})$ $[\mathrm{M}-\mathrm{H}]-$ calcd for C10H16O5, 215.09250; found, 215.0921.<smiles>COC(=O)CC1(C(=O)O)CN(C(C)=O)C1</smiles>

1-(tert-butoxycarbonyl)-3-(2-methoxy-2-oxoethyl)azetidine-3-carboxylic acid (20) General Procedure B was followed using tert-butyl 3-(2-methoxy-2-oxo-ethylidene)azetidine-1carboxylate to afford 20 in $74 \%$ yield $(0.74 \mathrm{mmol})$ and analyzed by ${ }^{1} \mathrm{H}$ NMR. ${ }^{1} \mathbf{H}$ NMR (400 $\left.\mathrm{MHz}, \mathrm{CDCl}_{3}\right) \delta 4.33(\mathrm{~d}, J=9.0 \mathrm{~Hz}, 1 \mathrm{H}), 3.81(\mathrm{~d}, J=8.9 \mathrm{~Hz}, 1 \mathrm{H}), 3.70(\mathrm{~s}, 1 \mathrm{H}), 3.00(\mathrm{~s}, 1 \mathrm{H}) .{ }^{13} \mathrm{C}$ NMR $\left(126 \mathrm{MHz}, \mathrm{CDCl}_{3}\right) \delta 177.86,170.94,156.25,80.34,56.73(\mathrm{~d}, J=32.4 \mathrm{~Hz}), 52.01,39.45$, 28.30, 21.02. HRMS $(\mathrm{m} / \mathrm{z})[\mathrm{M}-\mathrm{H}]-$ calcd for C12H19NO6, 272.11396; found, 272.1140.<smiles>CCOC(=O)CC1(C(=O)O)COC1</smiles> 


\section{3-(2-ethoxy-2-oxoethyl)oxetane-3-carboxylic acid (21)}

General Procedure B was followed using ethyl 2-(oxetan-3-ylidene)acetate to afford $\mathbf{2 1}$ in 53\% yield $(99.5 \mathrm{mg}, 0.53 \mathrm{mmol}){ }^{1}{ }^{1} \mathrm{H}$ NMR $\left(400 \mathrm{MHz}, \mathrm{CDCl}_{3}\right) \delta 5.04(\mathrm{~d}, J=6.4 \mathrm{~Hz}, 2 \mathrm{H}), 4.53(\mathrm{~d}, J=$ $6.5 \mathrm{~Hz}, 2 \mathrm{H}), 4.15(\mathrm{q}, J=7.2 \mathrm{~Hz}, 2 \mathrm{H}), 3.12(\mathrm{~s}, 2 \mathrm{H}), 1.26(\mathrm{t}, J=7.1 \mathrm{~Hz}, 3 \mathrm{H}) .{ }^{13} \mathbf{C}$ NMR $(126$ $\left.\mathrm{MHz}, \mathrm{CDCl}_{3}\right) \delta 176.88,170.56,77.54,61.12,45.54,39.40,14.07$. HRMS $(\mathrm{m} / \mathrm{z})[\mathrm{M}-\mathrm{H}]-$ calcd for $\mathrm{C} 8 \mathrm{H} 12 \mathrm{O} 5,187.0612$; found, 187.0611 .<smiles>C=CCOC(=O)C(CC(=O)O)[N+](=O)[O-]</smiles>

\section{4-(allyloxy)-3-methyl-4-oxobutanoic acid (23)}

General Procedure A was followed using 2-propenoic acid-2-methyl-2-propenyl ester (22) to afford 23 in $74 \%$ yield $(0.74 \mathrm{mmol})$ and analyzed by ${ }^{1} \mathrm{H}$ NMR. ${ }^{1} \mathbf{H}$ NMR $\left(400 \mathrm{MHz}, \mathrm{CDCl}_{3}\right) \delta$ $5.98-5.83(\mathrm{~m}, 1 \mathrm{H}), 5.32(\mathrm{dq}, J=17.2,1.6 \mathrm{~Hz}, 1 \mathrm{H}), 5.23(\mathrm{dt}, J=10.5,1.3 \mathrm{~Hz}, 1 \mathrm{H}), 4.60(\mathrm{dt}, J=$ $5.8,1.5 \mathrm{~Hz}, 2 \mathrm{H}), 2.94(\mathrm{dq}, J=12.8,7.1 \mathrm{~Hz}, 1 \mathrm{H}), 2.81(\mathrm{dd}, J=16.9,8.2 \mathrm{~Hz}, 1 \mathrm{H}), 2.47$ (dd, $J=$ $16.9,5.9 \mathrm{~Hz}, 1 \mathrm{H}), 1.26(\mathrm{~d}, J=7.1 \mathrm{~Hz}, 3 \mathrm{H}) .{ }^{13} \mathbf{C} \mathbf{~ N M R}\left(126 \mathrm{MHz}, \mathrm{CDCl}_{3}\right) \delta 177.44,174.75$, 131.98, 118.20, 65.40, 37.27, 35.58, 16.96. HRMS $(\mathrm{m} / \mathrm{z})[\mathrm{M}-\mathrm{H}]-$ calcd for C8H12O4, 171.06628; found, 171.0663 . 


\section{Scale-Up Setup-up and Procedure}

\section{Scaleup Procedure}

Potassium formate (4.627 g, 1.10 equiv, $55.00 \mathrm{mmol}$ ) and 4DPAIPN (4.0 mg, 0.00010 equiv, 5.0 $\mu \mathrm{mol})$ were added to a $1 \mathrm{~L}$ SCHOTT bottle (oven-dried, cooled in desiccator). Styrene* (5.208 g, $5.75 \mathrm{~mL}, 1$ equiv, $50.00 \mathrm{mmol})$, Methyl 2-sulfanylbenzoate $(420 \mathrm{mg}, 344 \mu \mathrm{L}, 0.0500$ equiv, 2.50 $\mathrm{mmol}$ ), and $750 \mathrm{~mL}$ DMSO were added to the bottle and capped. The reaction was irradiated with 4 of the $467 \mathrm{~nm}$ Kessil lamps and 4 fans for $8.5 \mathrm{~h}$.

*Filter off the inhibitor by passing through $\sim 1$ in basic alumina immediately prior to use.

After the reaction was complete, the reaction was transferred to a 3 separate 1 L SCHOTT bottles and $600 \mathrm{~mL}$ EtOAc was added to each. The mixtures were shaken and then left in the fridge for $24 \mathrm{~h}$. The precipitate was then filtered, rinsed with $1 \mathrm{~L}$ EtOAc, and dried under vacuum heating to $40{ }^{\circ} \mathrm{C}$.<smiles>O=C(O)CCc1ccccc1</smiles>

\section{Potassium 3-phenylpropanoate (24)}

The above general procedure was followed to afford $\mathbf{2 4}$ in $79 \%$ yield $(7.44 \mathrm{~g}, 39.5 \mathrm{mmol}) .{ }^{\mathbf{1}} \mathbf{H}$ NMR $\left(400 \mathrm{MHz}, \mathrm{D}_{2} \mathrm{O}\right) \delta 7.31-7.12(\mathrm{~m}, 5 \mathrm{H}), 2.79(\mathrm{t}, J=7.7 \mathrm{~Hz}, 2 \mathrm{H}), 2.39$ (t, $\left.J=7.7 \mathrm{~Hz}, 2 \mathrm{H}\right)$. The ${ }^{1} \mathrm{H}$ NMR spectrum is in agreement with those reported in the literature. ${ }^{13}$
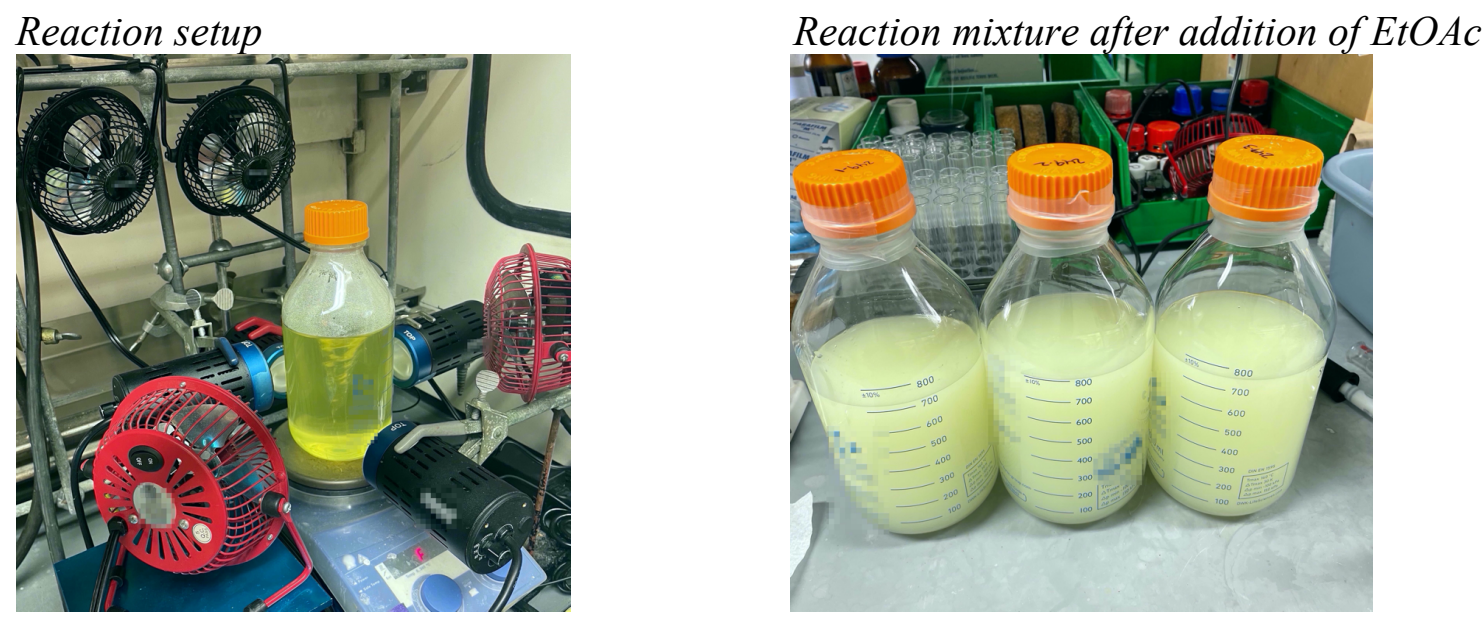
Reaction mixture after $24 \mathrm{~h}$ in fridge

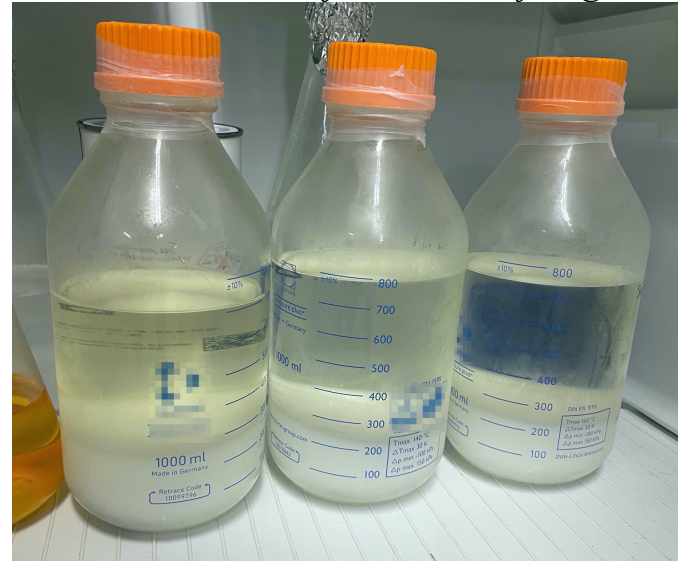

Pure carboxylate salt

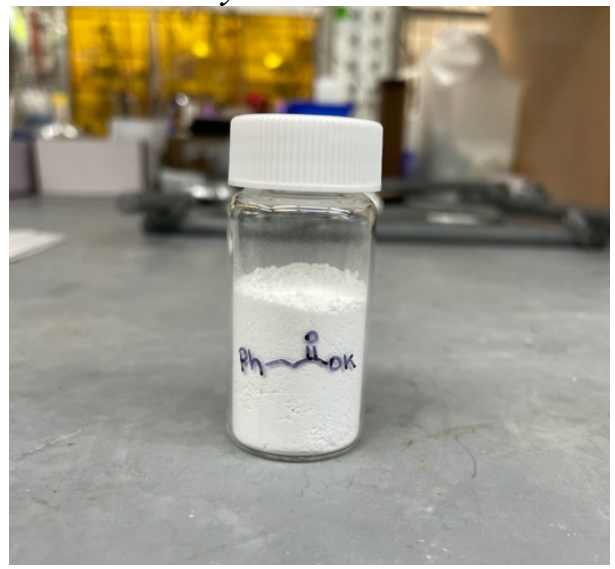



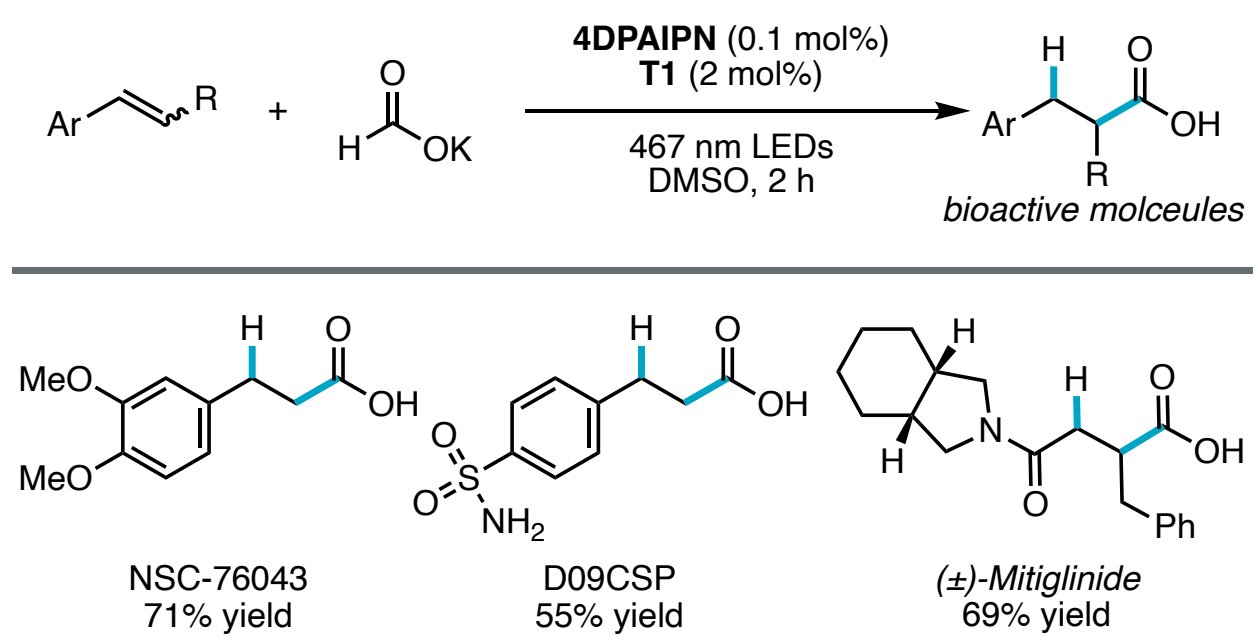

Scheme S9. Synthesis of bioactive molecules under standard conditions<smiles>COc1ccc(CCC(=O)O)cc1OC</smiles>

\section{3-(3,4-dimethoxyphenyl)propanoic-1 acid}

General Procedure A was followed using 1,2-dimethoxy-4-vinylbenzene to afford the product in $71 \%$ yield $(0.71 \mathrm{mmol})$ and analyzed by ${ }^{1} \mathrm{H}$ NMR. ${ }^{1} \mathbf{H}$ NMR $\left(400 \mathrm{MHz}, \mathrm{CDCl}_{3}\right) \delta 6.88-6.66$ $(\mathrm{m}, 3 \mathrm{H}), 3.92-3.81(\mathrm{~m}, 6 \mathrm{H}), 2.90(\mathrm{t}, J=7.8 \mathrm{~Hz}, 2 \mathrm{H}), 2.70-2.60(\mathrm{~m}, 2 \mathrm{H})$. The ${ }^{1} \mathrm{H}$ NMR spectrum is in agreement with those reported in the literature. ${ }^{14}$<smiles>NS(=O)(=O)c1ccc(CCC(=O)O)cc1</smiles>

\section{3-(4-sulfamoylphenyl)propanoic acid}

General Procedure A was followed using 4-vinylbenzenesulfonamide to afford the product in $55 \%$ yield $(0.55 \mathrm{mmol})$ and analyzed by ${ }^{1} \mathrm{H}$ NMR. ${ }^{1} \mathbf{H}$ NMR (400 MHz, Acetone) $\delta 7.81(\mathrm{~d}, J=$ $8.4 \mathrm{~Hz}, 2 \mathrm{H}), 7.43(\mathrm{~d}, J=8.3 \mathrm{~Hz} 2 \mathrm{H}), 6.54(\mathrm{~s}, 2 \mathrm{H}), 2.99$ (t, $J=7.6 \mathrm{~Hz}, 2 \mathrm{H}), 2.66$ (t, $J=7.5 \mathrm{~Hz}$, $2 \mathrm{H})$. The ${ }^{1} \mathrm{H}$ NMR spectrum is in agreement with those reported in the literature. ${ }^{15} \mathbf{H R M S}(\mathrm{m} / z)$ [M - H]- calcd for C9H11NO4S, 288.03360; found, 228.0337.<smiles>O=C(O)C(CC(=O)N1C[C@H]2CCCC[C@H]2C1)Cc1ccccc1</smiles> 


\section{2-benzyl-4-((3aR,7aS)-octahydro-2H-isoindol-2-yl)-4-oxobutanoic acid}

General Procedure A was followed using (E)-1-((3aR,7aS)-octahydro-2H-isoindol-2-yl)-4phenylbut-3-en-1-one to afford the product in $69 \%$ yield $(0.69 \mathrm{mmol})$ and analyzed by ${ }^{1} \mathrm{H} \mathrm{NMR}$. ${ }^{1} \mathbf{H}$ NMR $\left(400 \mathrm{MHz}, \mathrm{CDCl}_{3}\right) \delta 7.41-7.27(\mathrm{~m}, 2 \mathrm{H}), 7.27-7.13(\mathrm{~m}, 3 \mathrm{H}), 3.37-3.26(\mathrm{~m}, 1 \mathrm{H})$, $3.18-2.81(\mathrm{~m}, 3 \mathrm{H}), 2.76(\mathrm{ddd}, J=14.0,10.8,5.2 \mathrm{~Hz}, 1 \mathrm{H}), 2.44(\mathrm{td}, J=18.1,17.0,9.7 \mathrm{~Hz}, 2 \mathrm{H})$, $2.31-2.11(\mathrm{~m}, 2 \mathrm{H}), 1.69-1.30(\mathrm{~m}, 8 \mathrm{H})$. The ${ }^{1} \mathrm{H}$ NMR spectrum is in agreement with those reported in the literature. ${ }^{16}$ 


\section{1. ${ }^{13} \mathrm{C}$ Labeling Procedure}

\section{General Procedure - Limiting 13C Formate Conditions}

Sodium $\left({ }^{13} \mathrm{C}\right)$ formate $(27.6 \mathrm{mg}, 1.00$ equiv, $0.40 \mathrm{mmol})$ and 4DPAIPN (3.2 $\mathrm{mg}, 0.01$ equiv, 4.00 $\mu \mathrm{mol})$ were added to a 2 dram vial (oven-dried, cooled in desiccator). Alkene* (1.5 equiv, 0.60 mmol), methyl thiosalicylate $(2.8 \mu \mathrm{L}, 0.05$ equiv, $20.00 \mu \mathrm{mol})$, and $6 \mathrm{~mL}$ of DMSO were added to the vial and capped with a teflon cap. With fan cooling, irradiate with a $467 \mathrm{~nm}$ Kessil lamp for $8 \mathrm{~h}$.

*If alkene has an inhibitor present, filter off the inhibitor by passing through $\sim 1$ in basic alumina immediately prior to use.

Reaction mixture was transferred to a $250 \mathrm{~mL}$ sep funnel with $2 \times 2 \mathrm{~mL}$ EtOAc, $2 \times 2 \mathrm{~mL} \mathrm{10 \%} \mathrm{HCl}$ $20 \%$ brine aq solution, $2 \times 2 \mathrm{~mL}$ EtOAc. $100 \mathrm{~mL} \mathrm{10 \%} \mathrm{HCl} 20 \%$ brine aq solution was added and the mixture was extracted $3 \times 25 \mathrm{~mL}$ EtOAc. Combined organic layers were washed with $3 \times 20 \mathrm{~mL}$ $\mathrm{NaHCO}_{3}$ (collected in a separate flask from brine aq layer). The neutralized aq layer was acidified with conc $\mathrm{HCl}$ until $\mathrm{pH}=1$ (bright pink on $\mathrm{pH}$ paper). The aq layer was then extracted $4 \times 25 \mathrm{~mL}$ EtOAc. Combined organic layers were dried over $\mathrm{Na}_{2} \mathrm{SO}_{4}$ and $\mathrm{MgSO}_{4}$ and concentrated. $\mathrm{CH}_{2} \mathrm{Br}_{2}$ $(28 \mathrm{uL}, 1.00$ equiv, $0.40 \mathrm{mmol}$ ) was added as an internal standard and the yield was quantified via ${ }^{1} \mathrm{H}$ NMR. ${ }^{13} \mathrm{C}$ incorporation was determined via HRMS.<smiles>COc1ccc(CC[14C](=O)O)cc1OC</smiles>

\section{3-(3,4-dimethoxyphenyl)propanoic-1-13C acid (25)}

The above general procedure was followed using 1,2-dimethoxy-4-vinylbenzene to afford $\mathbf{2 5}$ in $51 \%$ yield $(0.20 \mathrm{mmol})$ and analyzed by ${ }^{1} \mathrm{H} \mathrm{NMR} .{ }^{1} \mathrm{H} \mathrm{NMR}\left(400 \mathrm{MHz}, \mathrm{CDCl}_{3}\right) \delta 6.93-6.84(\mathrm{~m}$, $1 \mathrm{H}), 6.81-6.70(\mathrm{~m}, 2 \mathrm{H}), 2.84(\mathrm{td}, J=7.8,4.2 \mathrm{~Hz}, 2 \mathrm{H}), 2.60(\mathrm{dd}, J=8.1,6.9 \mathrm{~Hz}, 2 \mathrm{H})$. Assigned by analogy to ${ }^{12} \mathrm{C}$ isotopologue. ${ }^{14}$ HRMS $(\mathrm{m} / \mathrm{z})[\mathrm{M}-\mathrm{H}]-$ calcd for $\mathrm{C} 10(13 \mathrm{C}) \mathrm{H} 14 \mathrm{O} 4,210.08533$; found, 210.0851. C11H14O4 detected with 2 orders of magnitude lower intensity.<smiles>NS(=O)(=O)c1ccc(CC[14C](=O)O)cc1</smiles>

\section{3-(4-sulfamoylphenyl)propanoic-1-13C acid (26)}

The above general procedure was followed using 4-vinylbenzenesulfonamide to afford $\mathbf{2 6}$ in $71 \%$ yield $(0.28 \mathrm{mmol})$ and analyzed by ${ }^{1} \mathrm{H}$ NMR. ${ }^{1} \mathrm{H}$ NMR $(400 \mathrm{MHz}$, Acetone) $\delta 7.84(\mathrm{~d}, J=$ $8.3 \mathrm{~Hz}, 2 \mathrm{H}), 7.47(\mathrm{~d}, H=8.4 \mathrm{~Hz}, 2 \mathrm{H}), 6.58(\mathrm{~s}, 2 \mathrm{H}), 3.01(\mathrm{td}, J=7.5,4.4 \mathrm{~Hz}, 2 \mathrm{H}), 2.68(\mathrm{p}, J=$ $7.8 \mathrm{~Hz}, 2 \mathrm{H})$. Assigned by analogy to ${ }^{12} \mathrm{C}$ isotopologue. HRMS $(\mathrm{m} / \mathrm{z})[\mathrm{M}-\mathrm{H}]-$ calcd for C8(13C)H11NO4S, 229.0370; found, 229.0369. C9H11NO4S detected with 2 orders of magnitude lower intensity. 


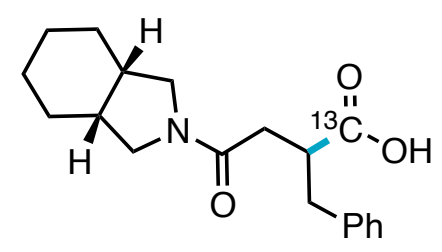

2-benzyl-4-((3aR,7aS)-octahydro-2H-isoindol-2-yl)-4-oxobutanoic-1-13C acid (27)

The above general procedure was followed using (E)-1-((3aR,7aS)-octahydro-2H-isoindol-2-yl)4-phenylbut-3-en-1-one to afford 27 in $74 \%$ yield $(0.30 \mathrm{mmol})$ and analyzed by ${ }^{1} \mathrm{H} \mathrm{NMR} .{ }^{1} \mathbf{H}$ NMR $\left(400 \mathrm{MHz}, \mathrm{CDCl}_{3}\right) \delta 7.41-7.27(\mathrm{~m}, 2 \mathrm{H}), 7.27-7.13(\mathrm{~m}, 3 \mathrm{H}), 3.37-3.26(\mathrm{~m}, 1 \mathrm{H}), 3.18-$ $2.81(\mathrm{~m}, 3 \mathrm{H}), 2.76(\mathrm{ddt}, J=13.9,10.2,3.5 \mathrm{~Hz}, 1 \mathrm{H}), 2.44(\mathrm{q}, J=5.8 \mathrm{~Hz}, 2 \mathrm{H}), 2.31-2.11(\mathrm{~m}$, 2H), $1.69-1.30(\mathrm{~m}, 8 \mathrm{H})$. Assigned by analogy to ${ }^{12} \mathrm{C}$ isotopologue. ${ }^{16}$ HRMS $(\mathrm{m} / \mathrm{z})[\mathrm{M}-\mathrm{H}]-$ calcd for C18(13C)H25NO3, 315.17957; found, 315.1795. C19H25NO3 not detected. 


\section{Deuterium Labeling Procedure}

\section{General Procedure - D Formate Conditions}

DMSO was distilled over $\mathrm{CaH}_{2}$ and dried over $4 \AA$ MS before use to remove potential impurities and residual water that could alter the $\% \mathrm{D}$ incorporation. All glassware was oven-dried before use and reactions were setup in the glovebox.

Sodium formate $(7.5 \mathrm{mg}, 1.10$ equiv, $0.11 \mathrm{mmol}$ ) (Table 5 entries $2-3)$ or D-formate $(7.6 \mathrm{mg}, 1.10$ equiv, $0.11 \mathrm{mmol}$ ) (Table 5 entries 1 and 4$)$ and 4DPAIPN ( $0.8 \mathrm{mg}, 0.01$ equiv, $1.00 \mu \mathrm{mol})$ were added to a 1 dram vial. Styrene* $(11.5 \mu \mathrm{L}, 1.00$ equiv, $0.10 \mathrm{mmol})$, methyl thiosalicylate $(0.3 \mu \mathrm{L}$, 0.02 equiv, $2.00 \mu \mathrm{mol})$, mesitylene $(10.0 \mu \mathrm{L}, 0.58$ equiv, $0.058 \mathrm{mmol})$ as an internal standard, and $1.5 \mathrm{~mL}$ DMSO (Table 5 entries 1, 3, and 4) or d6-DMSO (Table 5 entry 2) were added and the vial was sealed with a septum cap. The vial was then removed from the glovebox and an Ar balloon was added. $\mathrm{D}_{2} \mathrm{O}\left(19.9 \mu \mathrm{L}, 11.0\right.$ equiv, $1.10 \mathrm{mmol}$ ) (entry 3) or $\mathrm{H}_{2} \mathrm{O}(19.8 \mu \mathrm{L}, 11.0$ equiv, 1.10 mmol) (entry 4) With fan cooling, irradiate with $467 \mathrm{~nm}$ Kessil for $4 \mathrm{~h}$.

*Filter off the inhibitor by passing through $\sim 1$ in basic alumina immediately prior to use.

Reaction mixture was transferred to a $125 \mathrm{~mL}$ sep funnel with $2 \times 2 \mathrm{~mL}$ EtOAc, $2 \times 2 \mathrm{~mL} 10 \% \mathrm{HCl}$ $20 \%$ brine aq solution, $2 \times 2 \mathrm{~mL}$ EtOAc. $25 \mathrm{~mL} \mathrm{10 \%} \mathrm{HCl} 20 \%$ brine aq solution was added and the mixture was extracted $3 \times 10 \mathrm{~mL}$ EtOAc. Combined organic layers were washed with $3 \times 20 \mathrm{~mL}$ $\mathrm{NaHCO}_{3}$ (collected in a separate flask from brine aq layer). The neutralized aq layer was acidified with conc $\mathrm{HCl}$ until $\mathrm{pH}=1$ (bright pink on $\mathrm{pH}$ paper). The aq was then extracted 4x10 mL EtOAc. Combined organic layers were dried over $\mathrm{Na}_{2} \mathrm{SO}_{4}$ and $\mathrm{MgSO}_{4}$ and concentrated. $\mathrm{CH}_{2} \mathrm{Br}_{2}(7 \mathrm{uL}$, 1.0 equiv, $0.10 \mathrm{mmol}$ ) was added as an internal standard and the yield was quantified via ${ }^{1} \mathrm{H}$ NMR.

Entry 1: D-formate

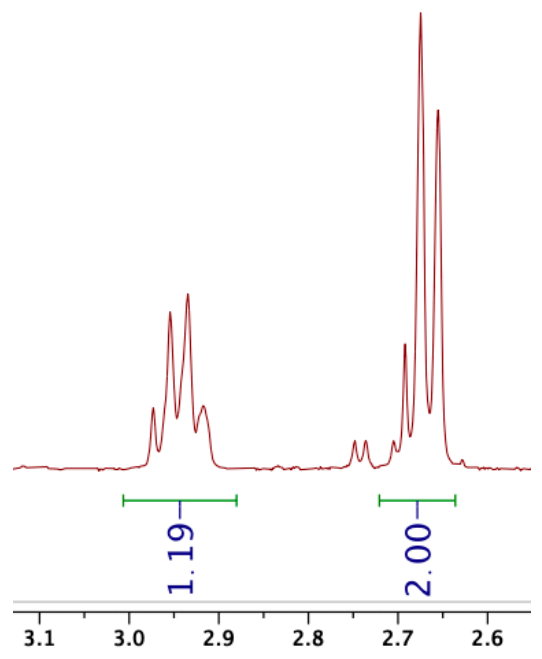

Entry 2: d6-DMSO

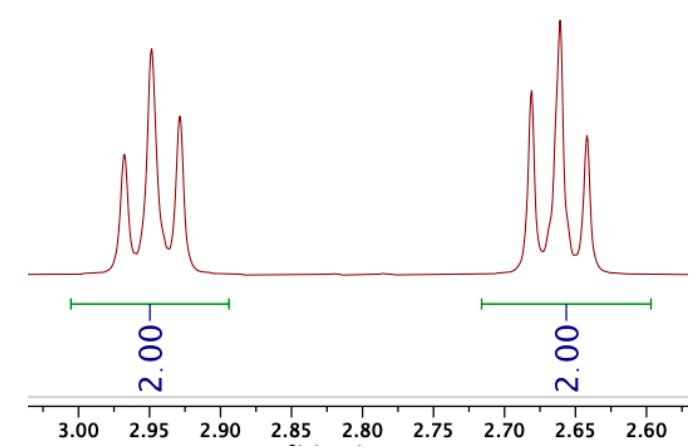



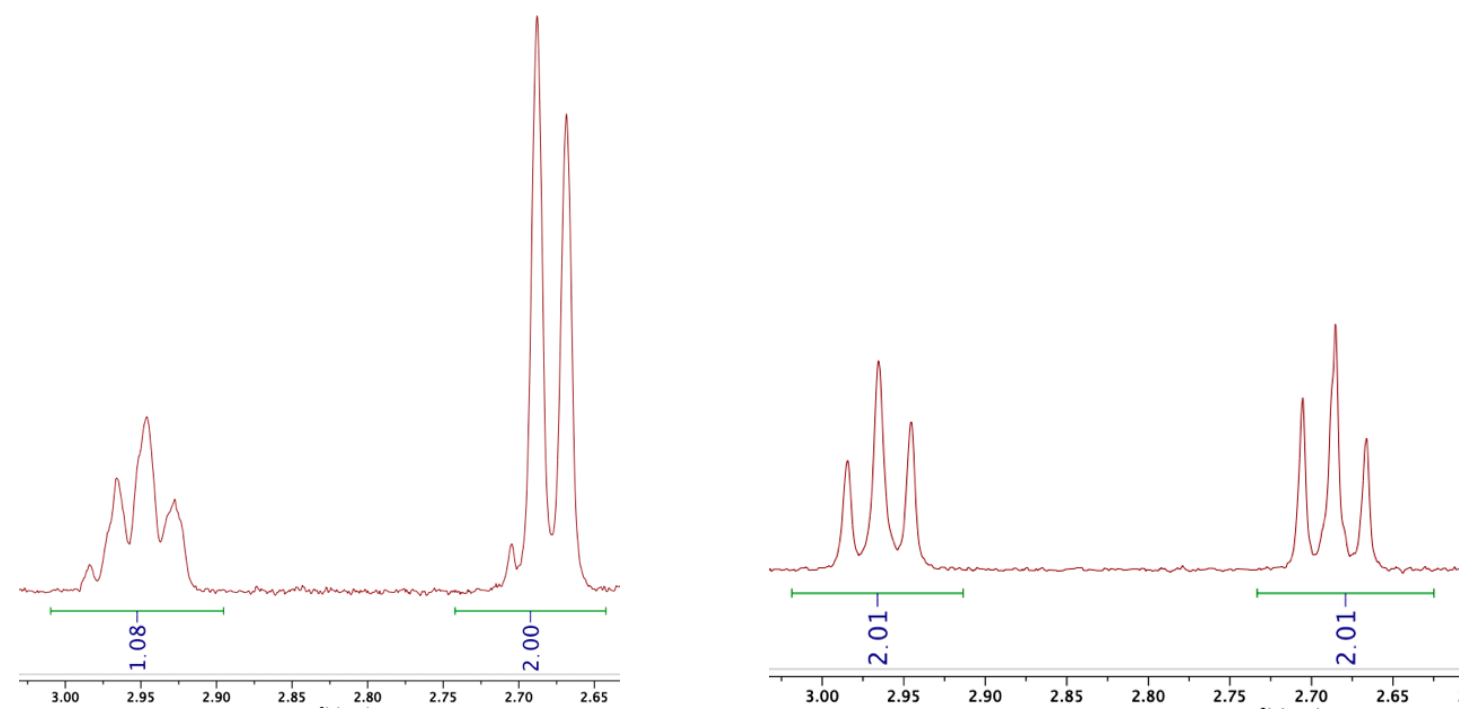

Figure S2. ${ }^{1} \mathrm{H}$ NMR Spectra from Table 5 
13. GC Calibration Curves

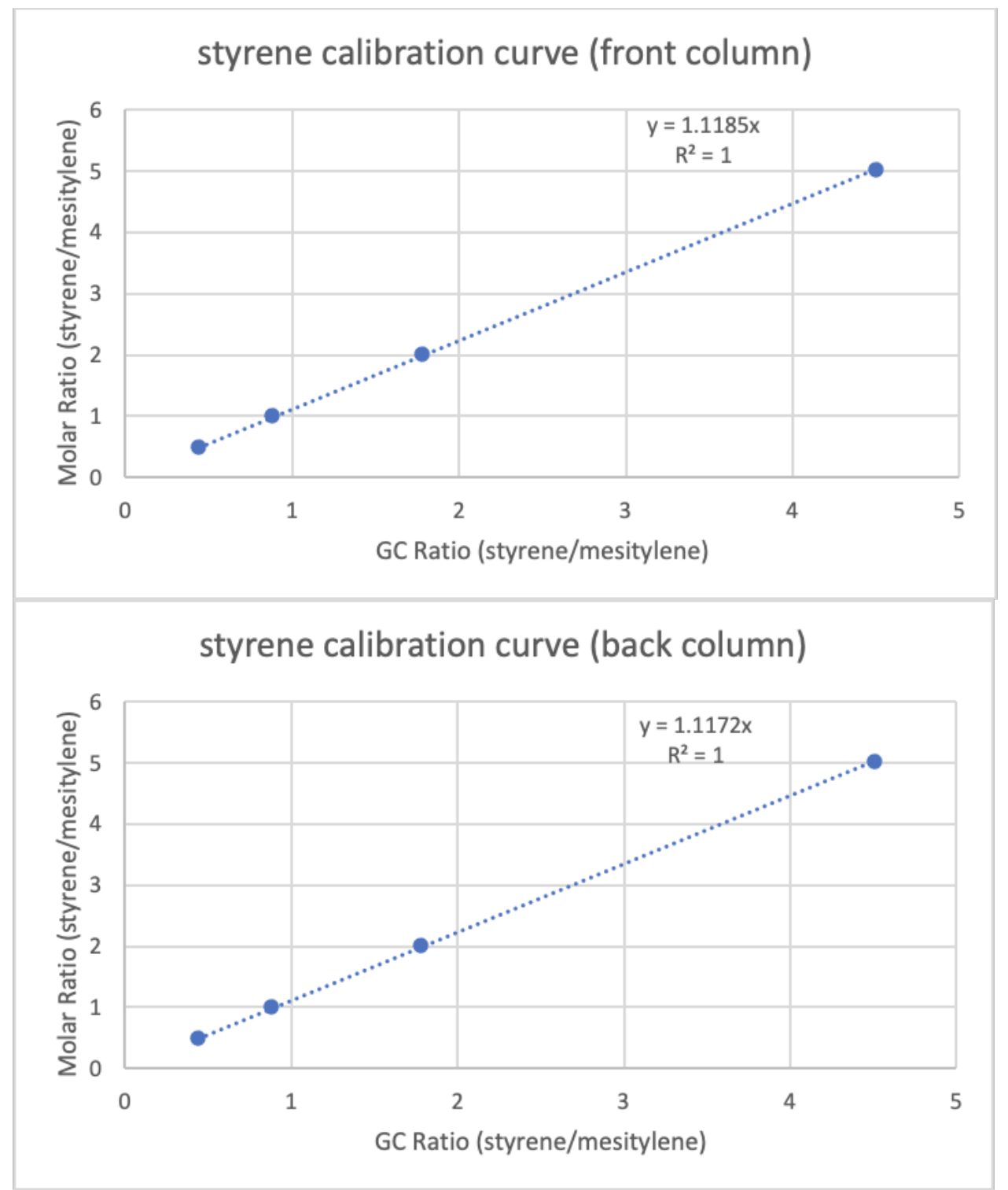



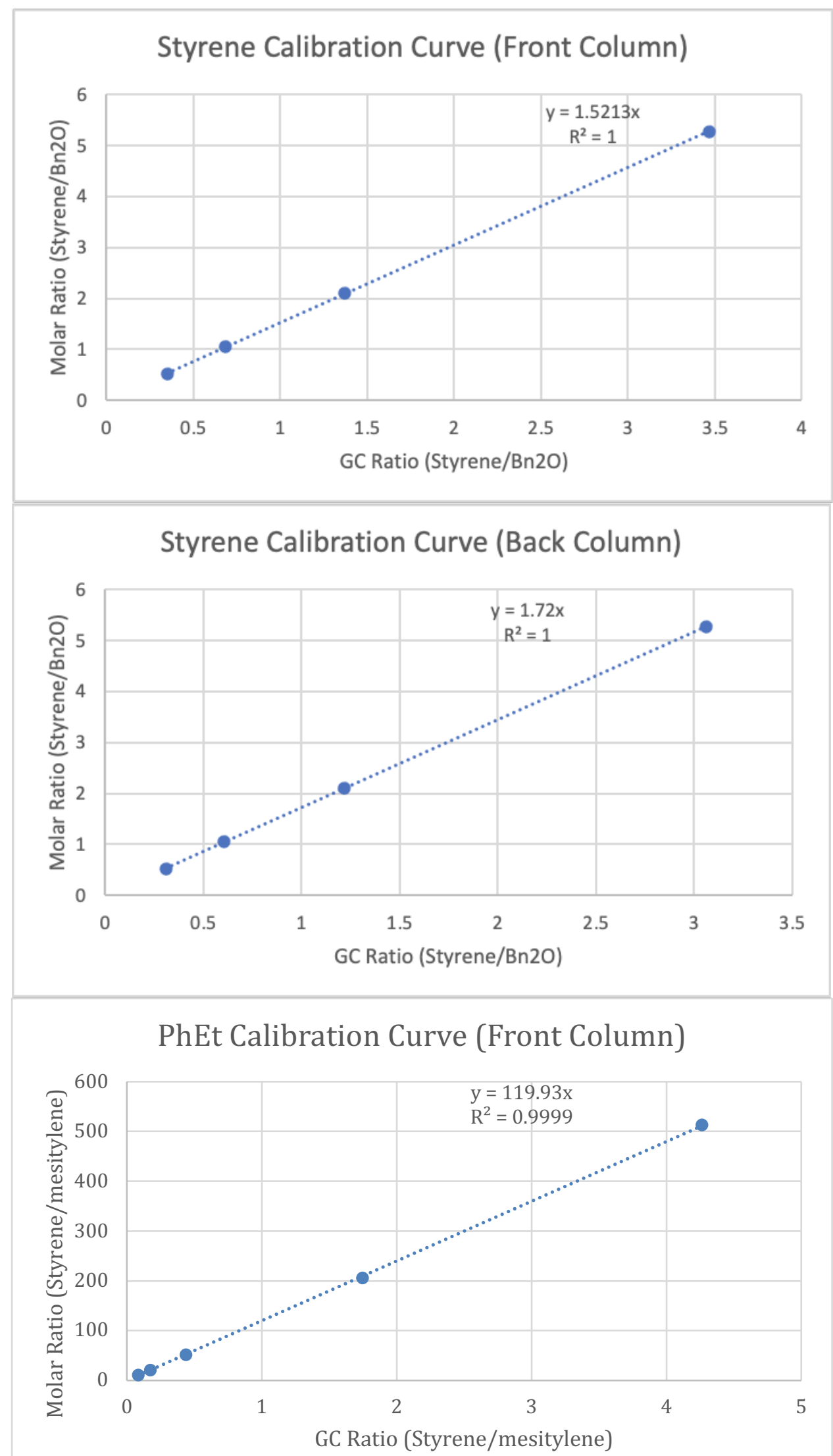

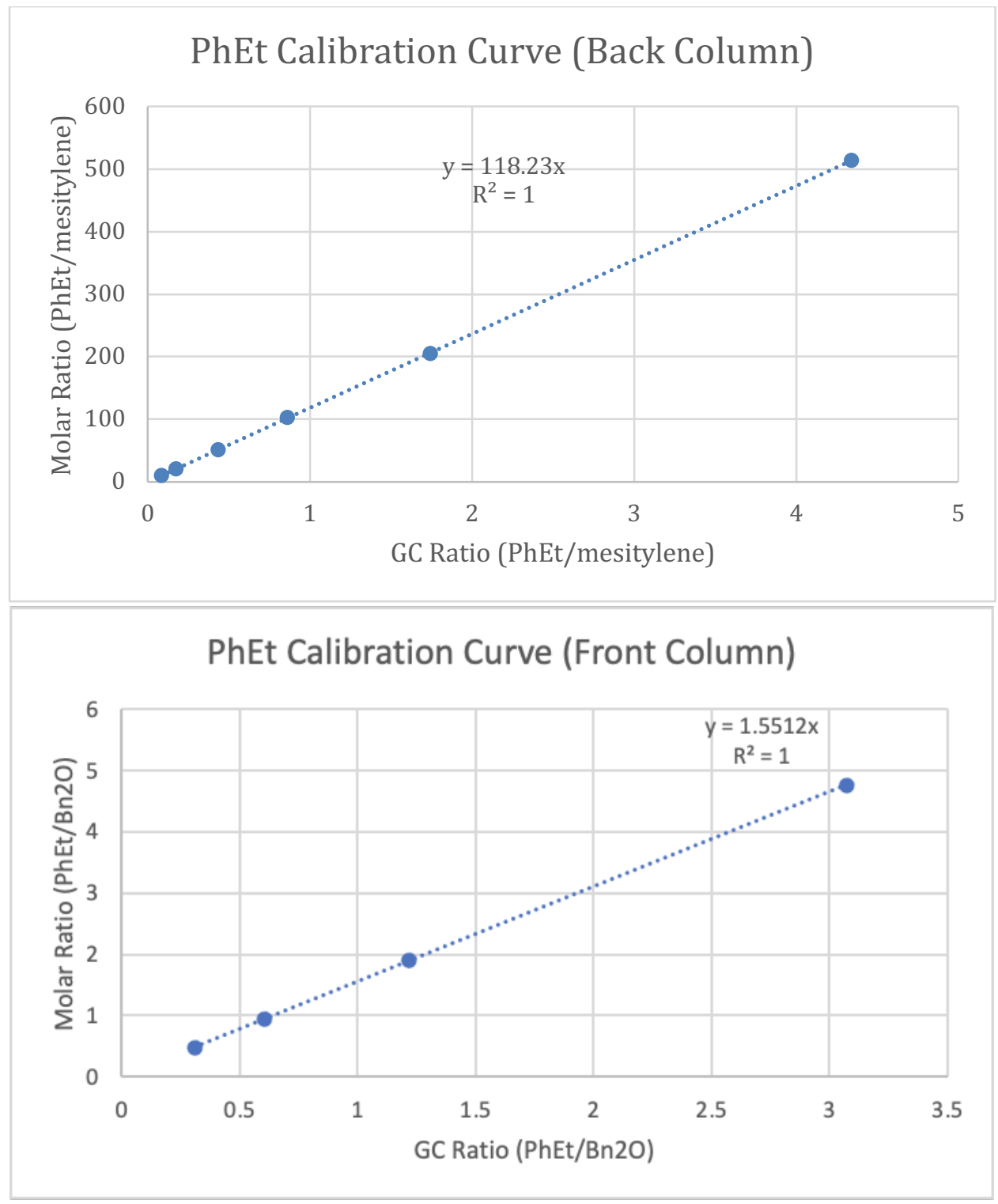


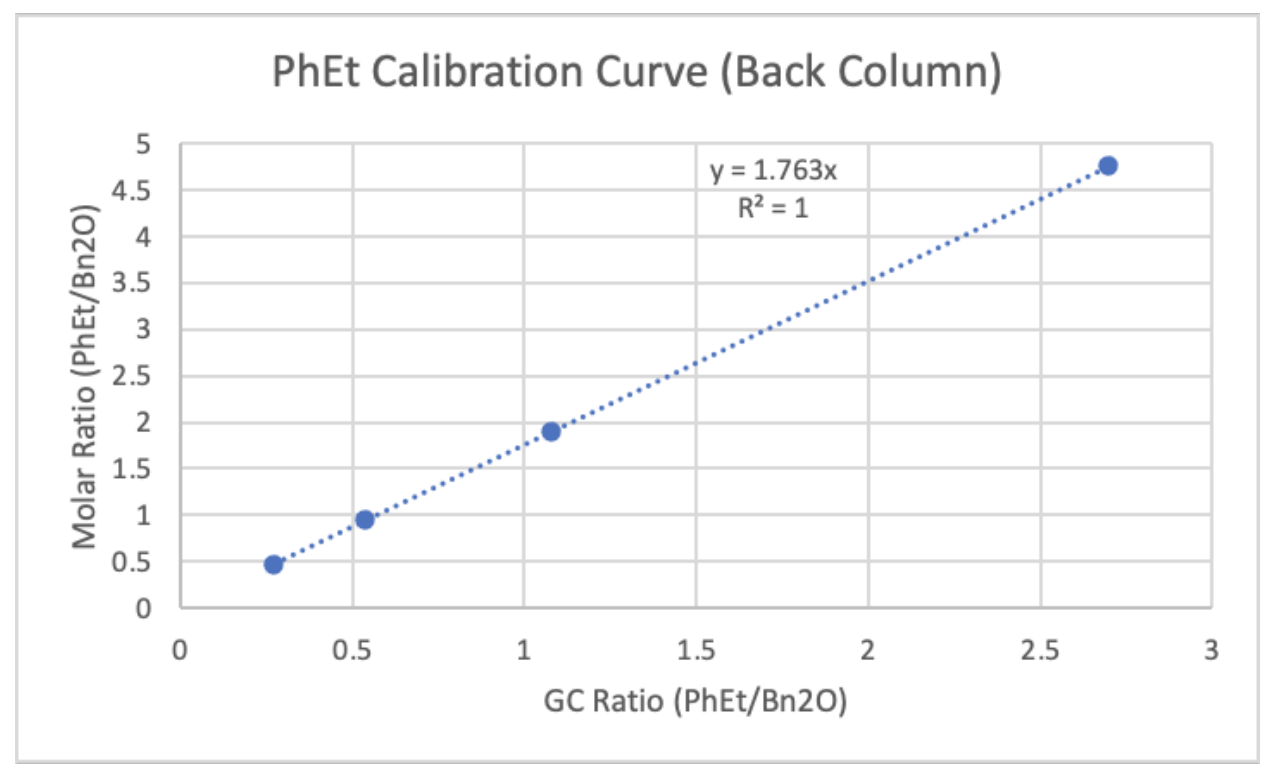




\section{Stern-Volmer}

In the glovebox, a $25 \mu \mathrm{M}$ solution of 4DPAIPN in DMSO was prepared with a given concentration of the quencher. The samples were irradiated at $435 \mathrm{~nm}$ and emission peak was measured at 532 nm. Quenching of 4DPAIPN* was observed with tetrabutylammonium (TBA) formate and T1.
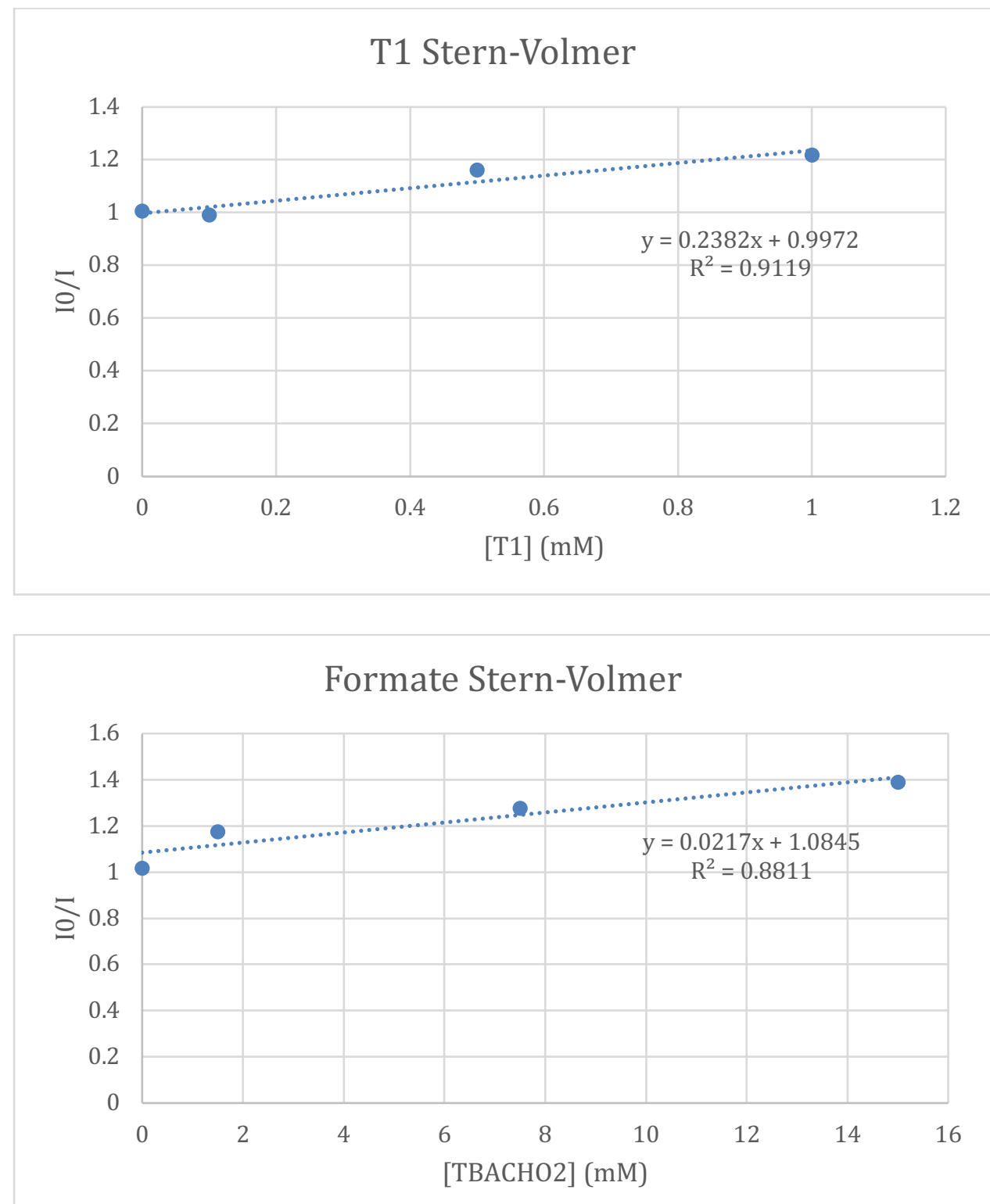

Note: TBA-formate was used instead of Na-formate because of poor solubility of the sodium counter ion. 
15. Cyclic Voltammetry

Sodium formate in $\mathrm{DMSO}\left(0.1 \mathrm{M} \mathrm{TBAPF}_{6}\right) E_{\mathrm{ox}}=1.25 \mathrm{~V} v s \mathrm{SCE}$

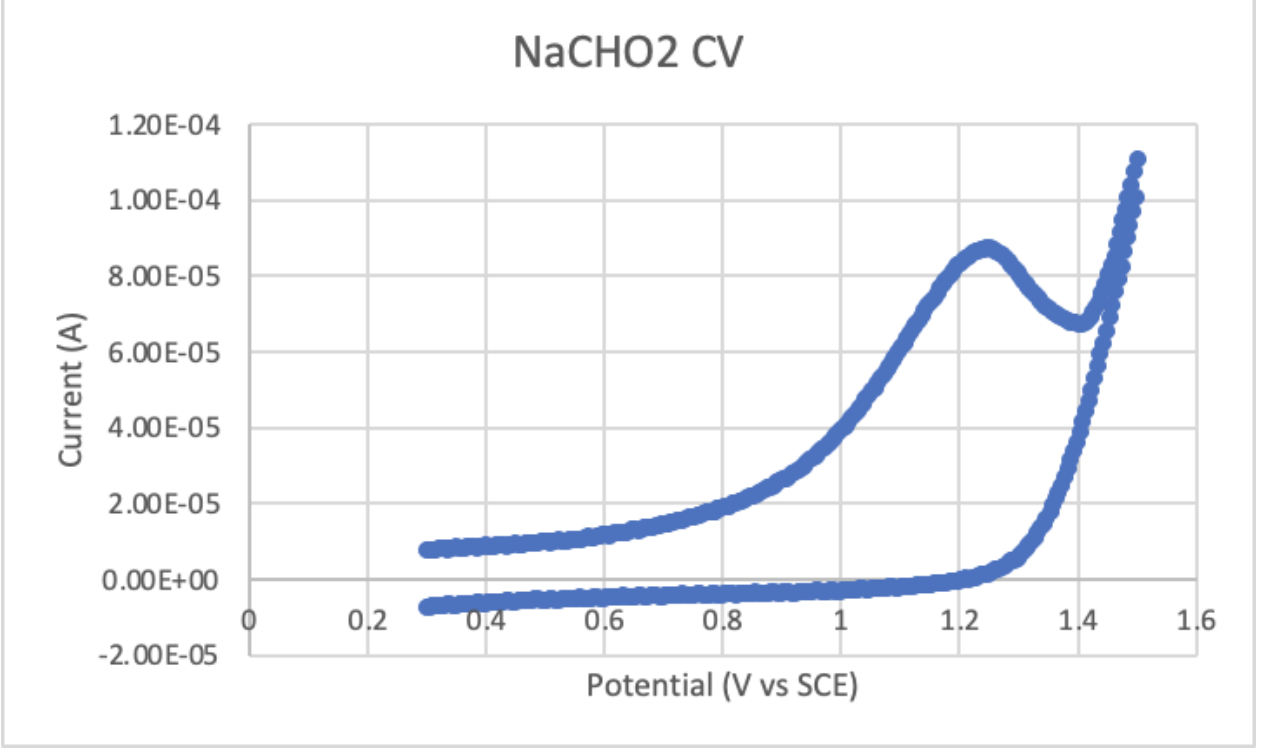


$\mathrm{KCHO}_{2}(65.5 \mathrm{mg}, 1$ equiv, $779 \mu \mathrm{mol})$ and $\mathrm{CH}_{2} \mathrm{Br}_{2}(134 \mathrm{mg}, 54.0 \mu \mathrm{L}, 0.988 \mathrm{Eq}, 769 \mu \mathrm{mol})$ were added to a 2 dram vial. DMSO-d6 $(1 \mathrm{~mL})$ was then added and the mixture was violently shaken for $30 \mathrm{~s}$ and $2 \times 10 \mathrm{~s}$. Solubility was determined via $1 \mathrm{H}$ NMR.

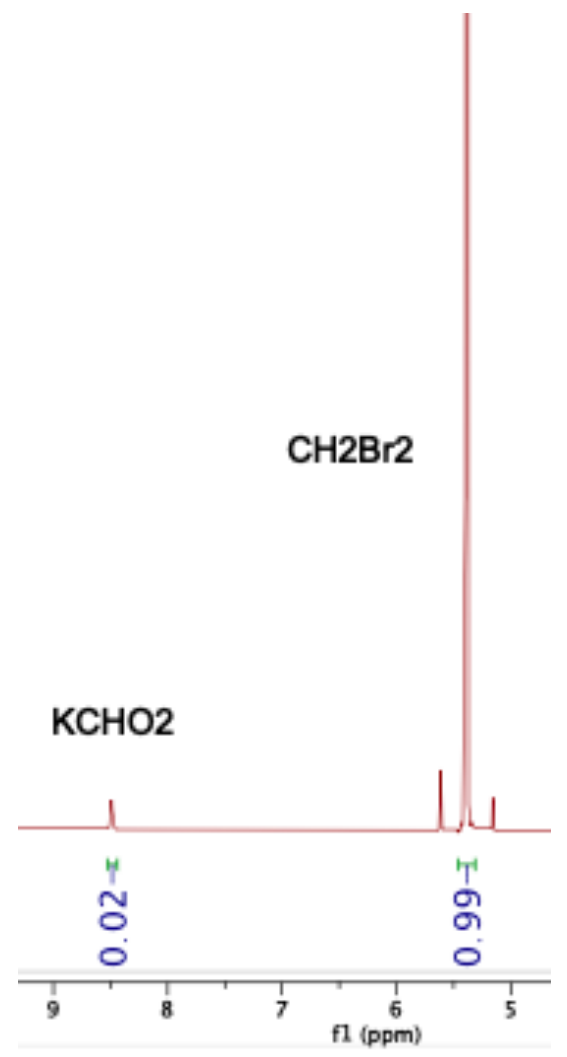

Figure S3. $\mathrm{KCHO}_{2}$ solubility test in DMSO 


\section{References}

(1) Chmiel, A.; Williams, O. P.; Chernowsky, C.; Yeung, C.; Wickens, Z. Non-Innocent Radical Ion Intermediates in Photoredox Catalysis: Parallel Reduction Modes Enable Coupling of Diverse Aryl Chlorides. 2021.

https://doi.org/10.26434/chemrxiv.14755134.v1.

(2) Seo, H.; Liu, A.; Jamison, T. F. Direct $\beta$-Selective Hydrocarboxylation of Styrenes with CO2 Enabled by Continuous Flow Photoredox Catalysis. J. Am. Chem. Soc. 2017, 139 (40), 13969-13972. https://doi.org/10.1021/jacs.7b05942.

(3) Conner, M. L.; Brown, M. K. Synthesis of 1,3-Substituted Cyclobutanes by AllenoateAlkene [2 + 2] Cycloaddition. J. Org. Chem. 2016, 81 (17), 8050-8060. https://doi.org/10.1021/acs.joc.6b01446.

(4) Garreau, M.; Le Vaillant, F.; Waser, J. C-Terminal Bioconjugation of Peptides through Photoredox Catalyzed Decarboxylative Alkynylation. Angew. Chem. Int. Ed. 2019, 58 (24), 8182-8186. https://doi.org/10.1002/anie.201901922.

(5) Pearson, A. J.; Lee, K. Some Studies on the Uses of 2-Bromoethyl and 2-Iodoethyl Ester Blocking Groups in Peptide Synthesis: Samarium Diiodide-Mediated Deprotection. $J$. Org. Chem. 1994, 59 (8), 2257-2260. https://doi.org/10.1021/jo00087a053.

(6) Muratake, H.; Amano, Y.; Toda, T.; Sugiyama, K.; Shudo, K. Synthesis of Am80 (Tamibarotene) Prodrug Candidates, Congeners and Metabolites. Chem. Pharm. Bull. (Tokyo) 2013, 61 (8), 846-852. https://doi.org/10.1248/cpb.c13-00356.

(7) Grimm, S. H.; Gagestein, B.; Keijzer, J. F.; Liu, N.; Wijdeven, R. H.; Lenselink, E. B.; Tuin, A. W.; van den Nieuwendijk, A. M. C. H.; van Westen, G. J. P.; van Boeckel, C. A. A.; Overkleeft, H. S.; Neefjes, J.; van der Stelt, M. Comprehensive Structure-ActivityRelationship of Azaindoles as Highly Potent FLT3 Inhibitors. Bioorg. Med. Chem. 2019, 27 (5), 692-699. https://doi.org/10.1016/j.bmc.2019.01.006.

(8) Miles, K. C.; Abrams, M. L.; Landis, C. R.; Stahl, S. S. KetoABNO/NOx Cocatalytic Aerobic Oxidation of Aldehydes to Carboxylic Acids and Access to $\alpha$-Chiral Carboxylic Acids via Sequential Asymmetric Hydroformylation/Oxidation. Org. Lett. 2016, 18 (15), 3590-3593. https://doi.org/10.1021/acs.orglett.6b01598.

(9) Montanaro, S.; Ravelli, D.; Merli, D.; Fagnoni, M.; Albini, A. Decatungstate As Photoredox Catalyst: Benzylation of Electron-Poor Olefins. Org. Lett. 2012, 14 (16), 4218-4221. https://doi.org/10.1021/ol301900p.

(10) Ikeda, T.; Zhang, Z.; Motoyama, Y. Hydrosilane-Promoted Facile Deprotection of TertButyl Groups in Esters, Ethers, Carbonates, and Carbamates. Adv. Synth. Catal. 2019, 361 (4), 673-677. https://doi.org/10.1002/adsc.201801279.

(11) Huang He; Ye Jian-Heng; Zhu Lei; Ran Chuan-Kun; Miao Meng; Wang Wei; Chen Hanjiao; Zhou Wen-Jun; Lan Yu; Yu Bo; Yu Da-Gang. Visible-Light-Driven AntiMarkovnikov Hydrocarboxylation of Acrylates and Styrenes with CO2. CCS Chem. 0 (0). https://doi.org/10.31635/ccschem.020.202000374.

(12) Xu, S.; Shang, M.-Y.; Liu, G.-X.; Xu, F.; Wang, X.; Shou, C.-C.; Cai, S.-Q. Chemical Constituents from the Rhizomes of Smilax Glabra and Their Antimicrobial Activity. Molecules 2013, 18 (5), 5265-5287. https://doi.org/10.3390/molecules18055265.

(13) Li, J.; Lear, M. J.; Hayashi, Y. Autoinductive Conversion of $\alpha, \alpha$-Diiodonitroalkanes to Amides and Esters Catalysed by Iodine Byproducts under O2. Chem. Commun. 2018, 54 (49), 6360-6363. https://doi.org/10.1039/C8CC03191F. 
(14) Wang, Y.; Cao, X.; Zhao, L.; Pi, C.; Ji, J.; Cui, X.; Wu, Y. Generalized Chemoselective Transfer Hydrogenation/Hydrodeuteration. Adv. Synth. Catal. 2020, 362 (19), 4119-4129. https://doi.org/10.1002/adsc.202000759.

(15) Kanfar, N.; Tanc, M.; Dumy, P.; Supuran, C. T.; Ulrich, S.; Winum, J.-Y. Effective Access to Multivalent Inhibitors of Carbonic Anhydrases Promoted by Peptide Bioconjugation. Chem. - Eur. J. 2017, 23 (28), 6788-6794. https://doi.org/10.1002/chem.201700241.

(16) Yamaguchi, T.; Yanagi, T.; Hokari, H.; Mukaiyama, Y.; Kamijo, T.; Yamamoto, I. Preparation of Optically Active Succinic Acid Derivatives. I. Optical Resolution of 2Benzyl-3-(Cis-Hexahydroisoindolin-2-Ylcarbonyl)-Propionic Acid. Chem. Pharm. Bull. (Tokyo) 1997, 45 (9), 1518-1520. https://doi.org/10.1248/cpb.45.1518. 
18. NMR Spectra 


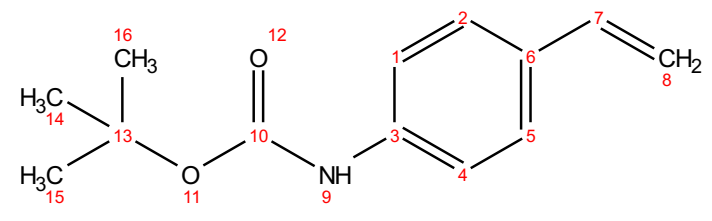

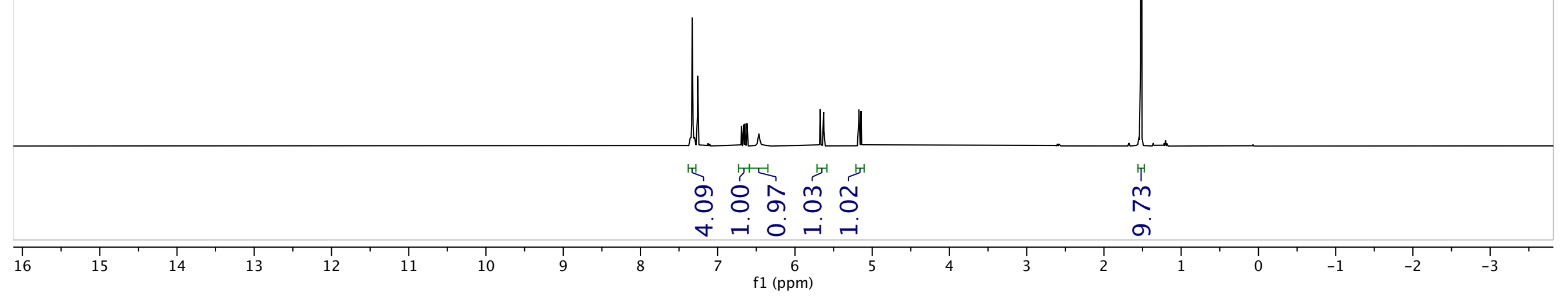


<smiles>C[Si]1(C)OB(c2ccc(P=O)cc2)OP1(C)(C)C</smiles>

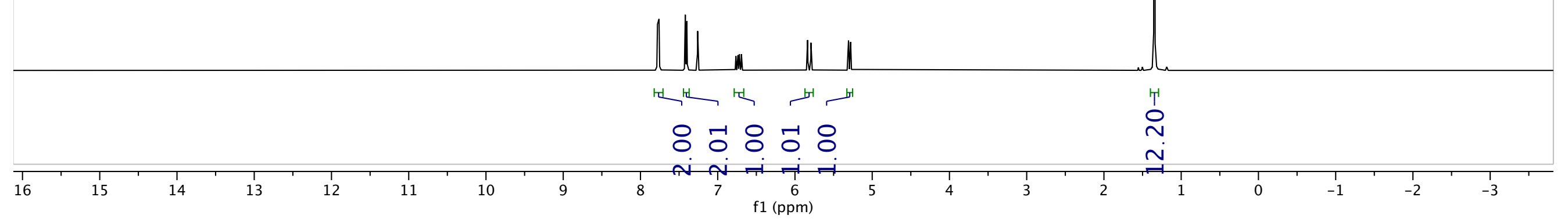


PROTON_D1_2.mk (zg30)<smiles>Cc1ccc(C=P)cc1</smiles>

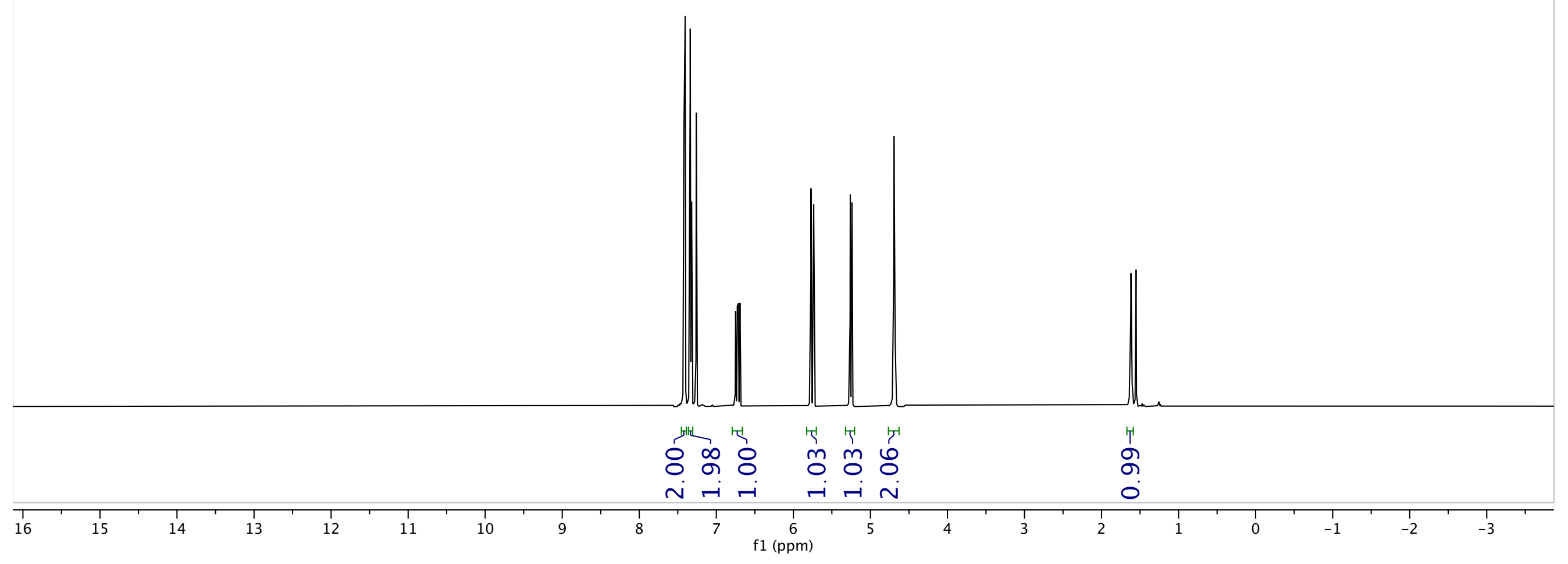



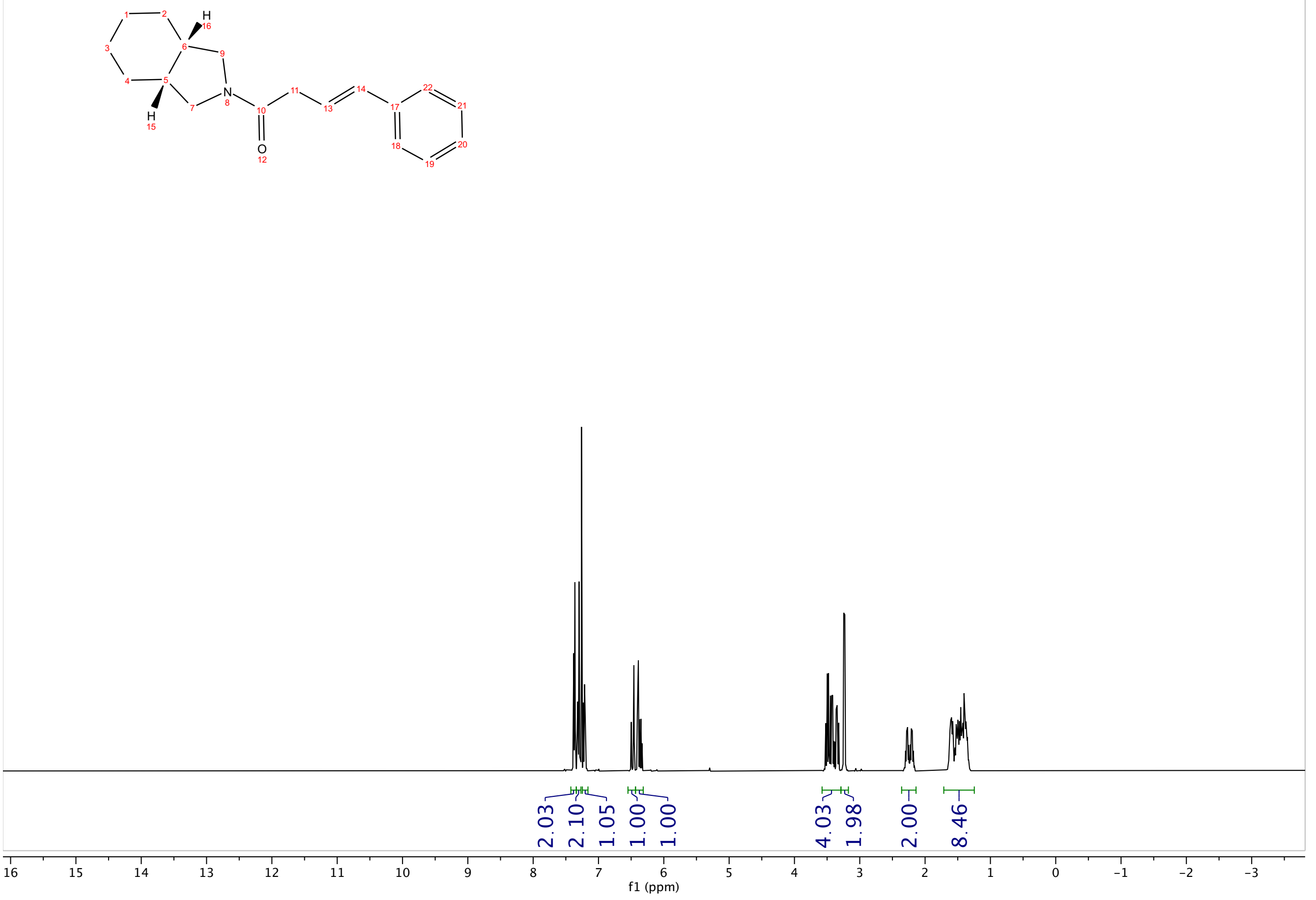
<smiles>[124In]</smiles>

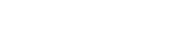

(

ไป

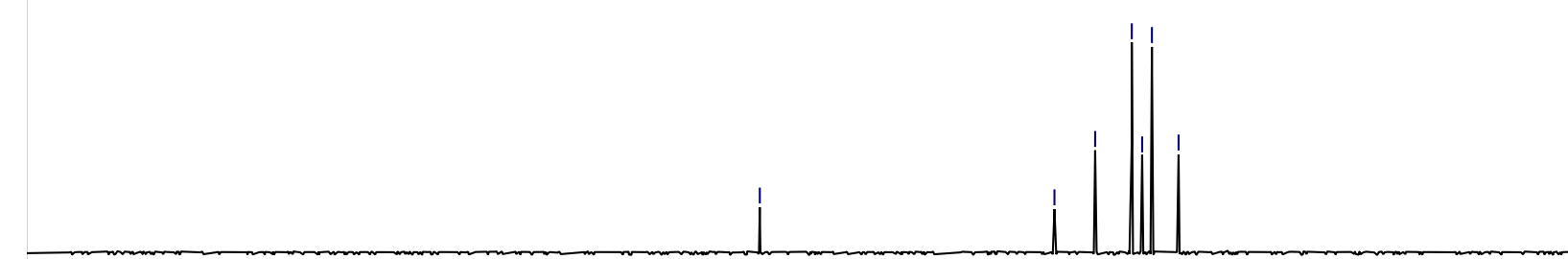



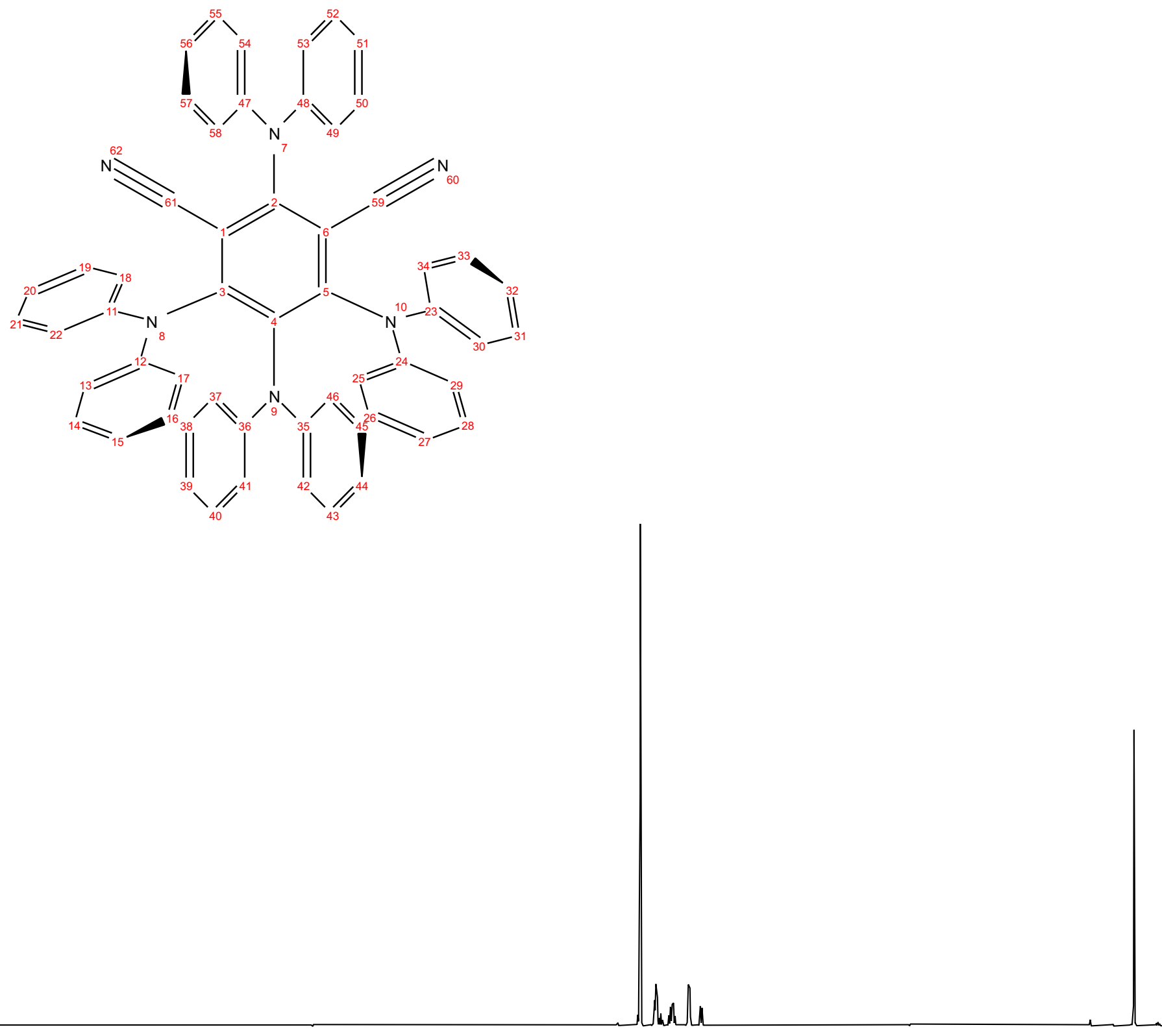

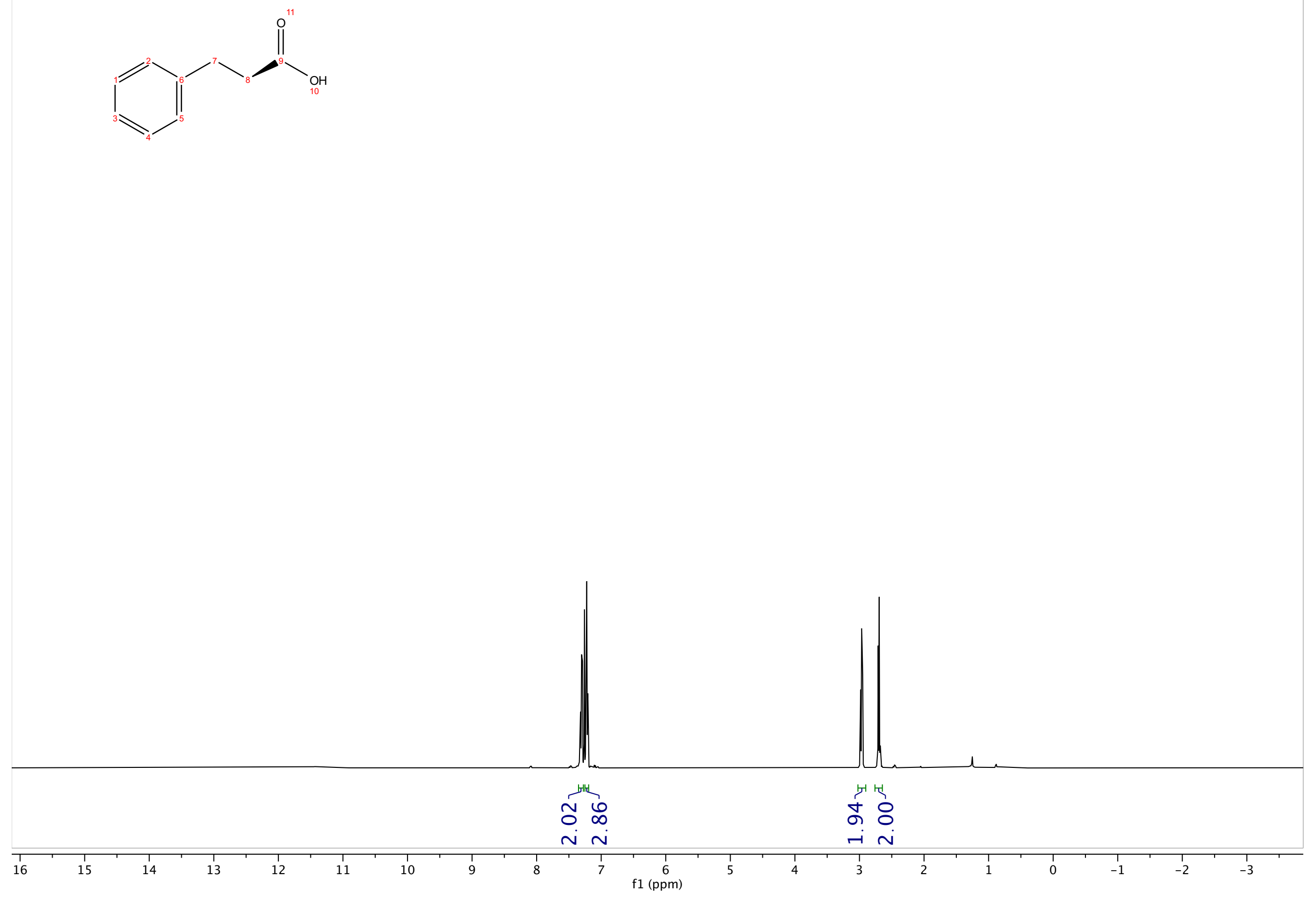

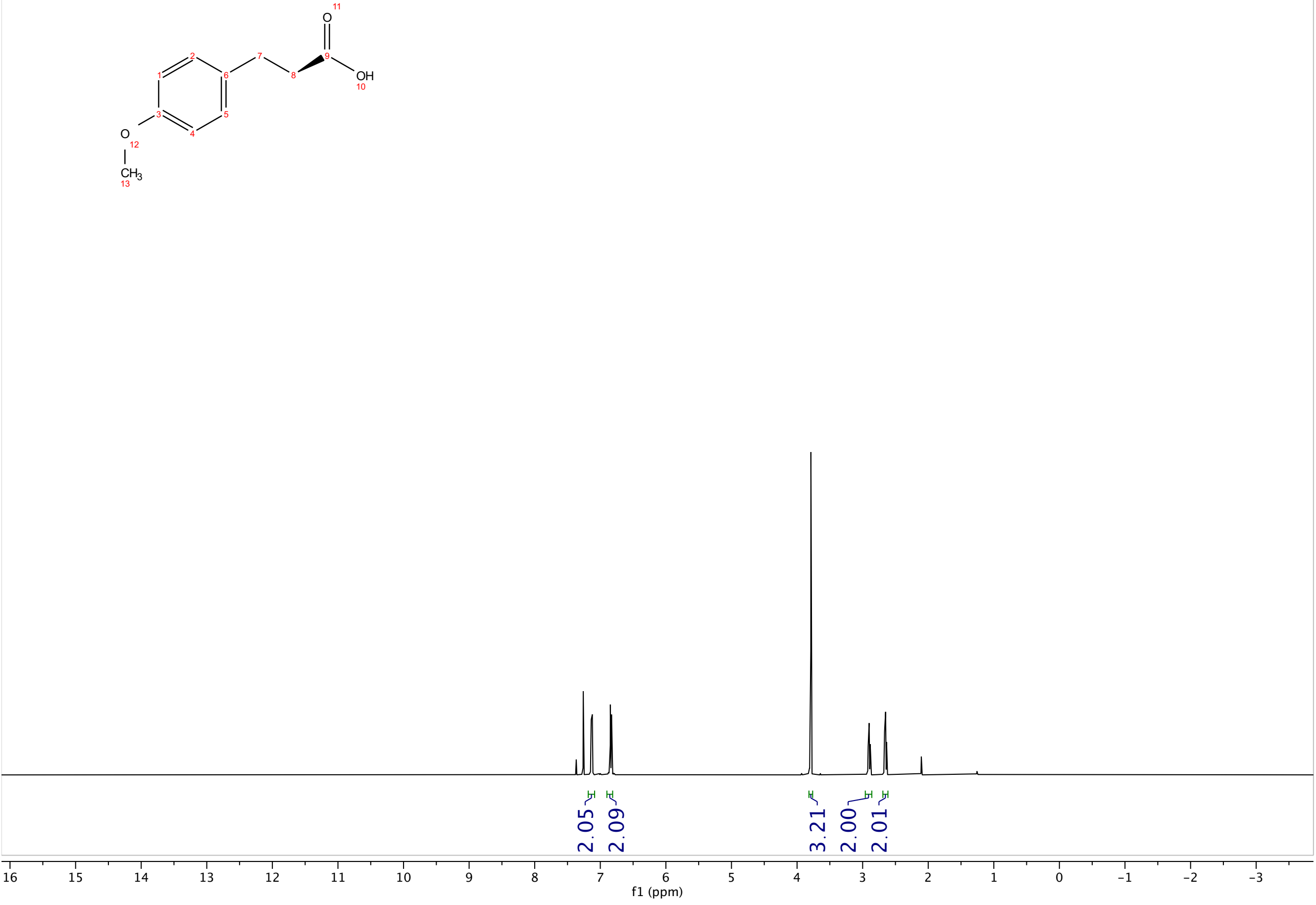

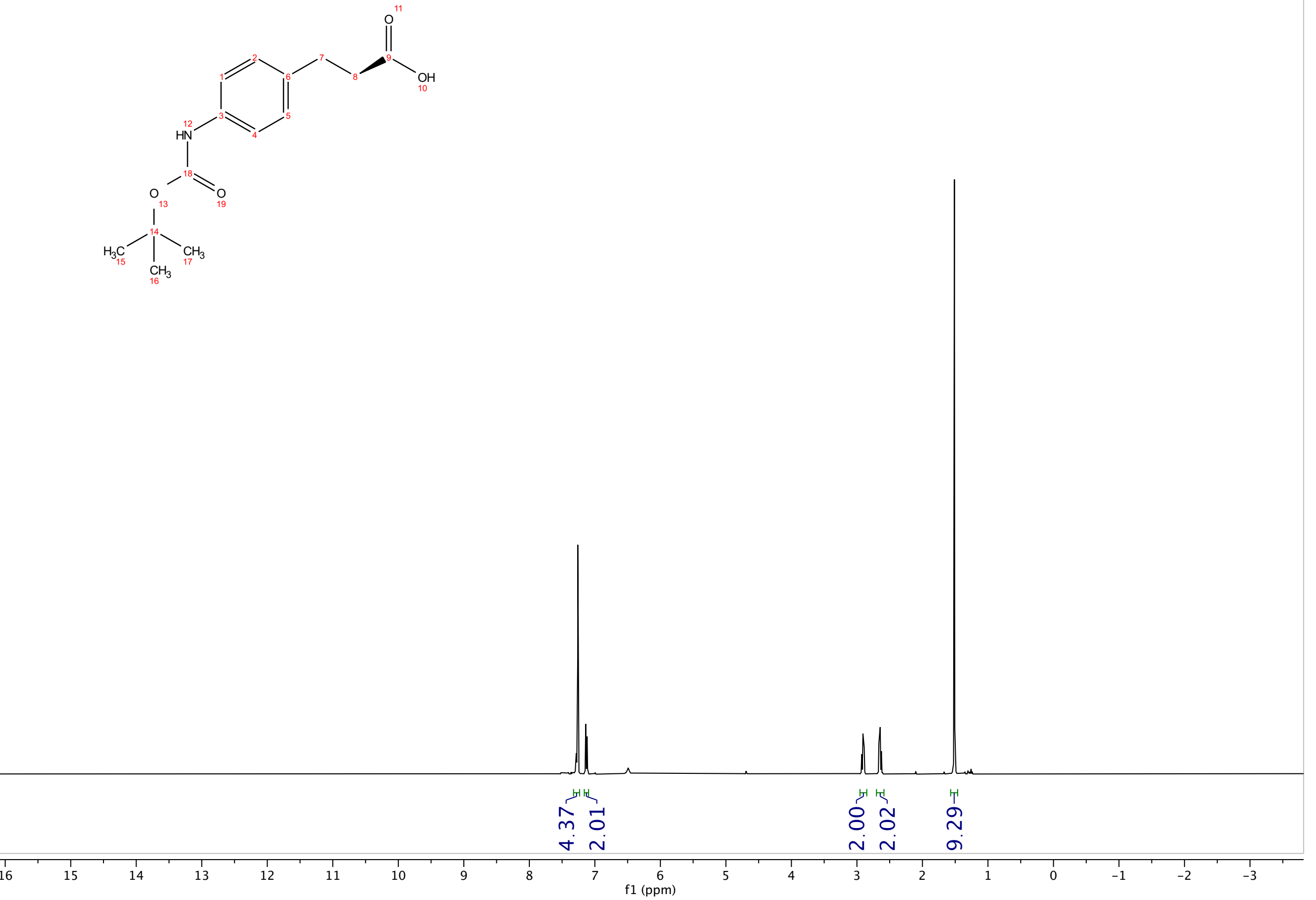

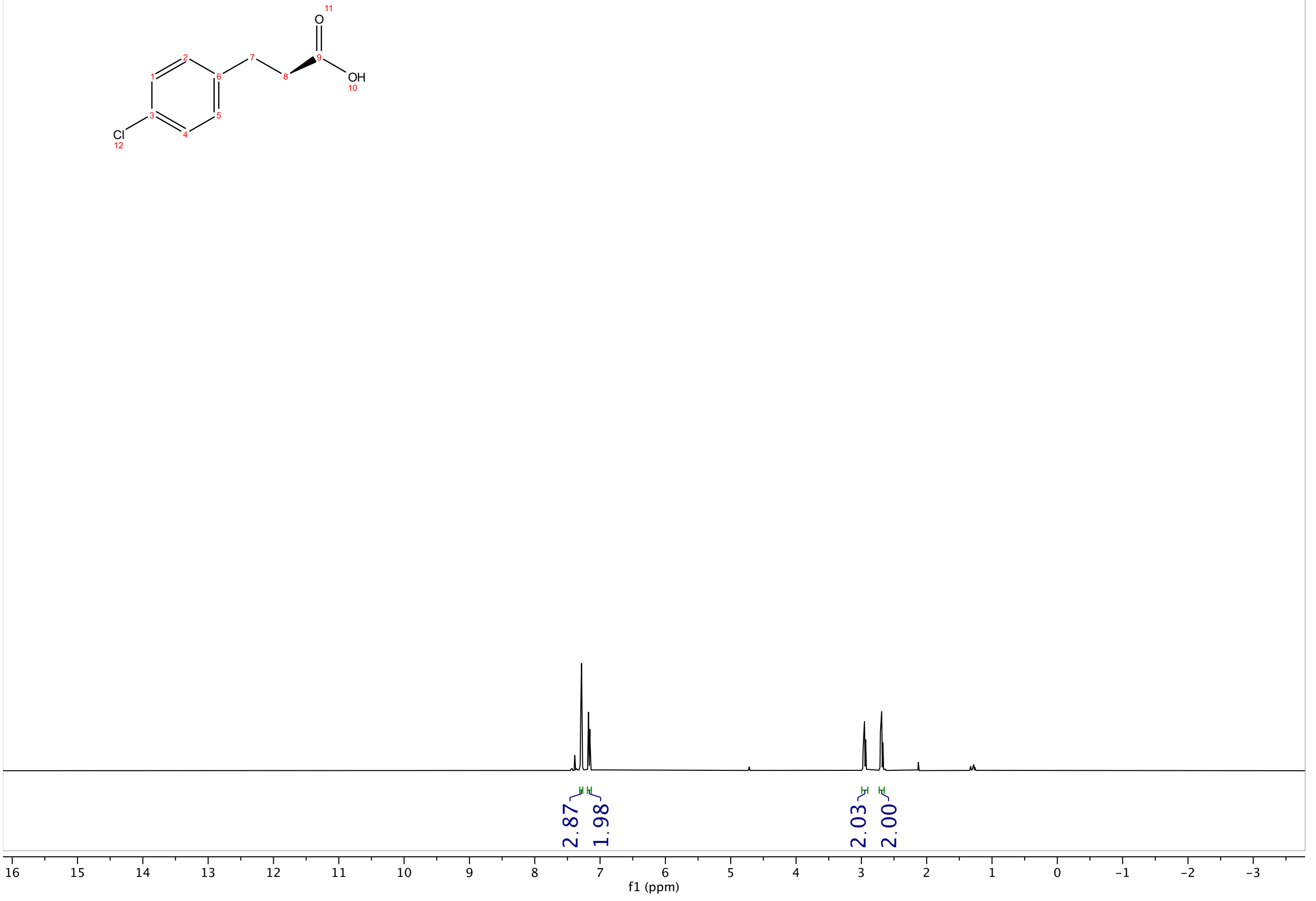
<smiles>CC(=O)CCc1ccc(C2NC(=O)C(C)(C)C2(C)C)cc1</smiles>

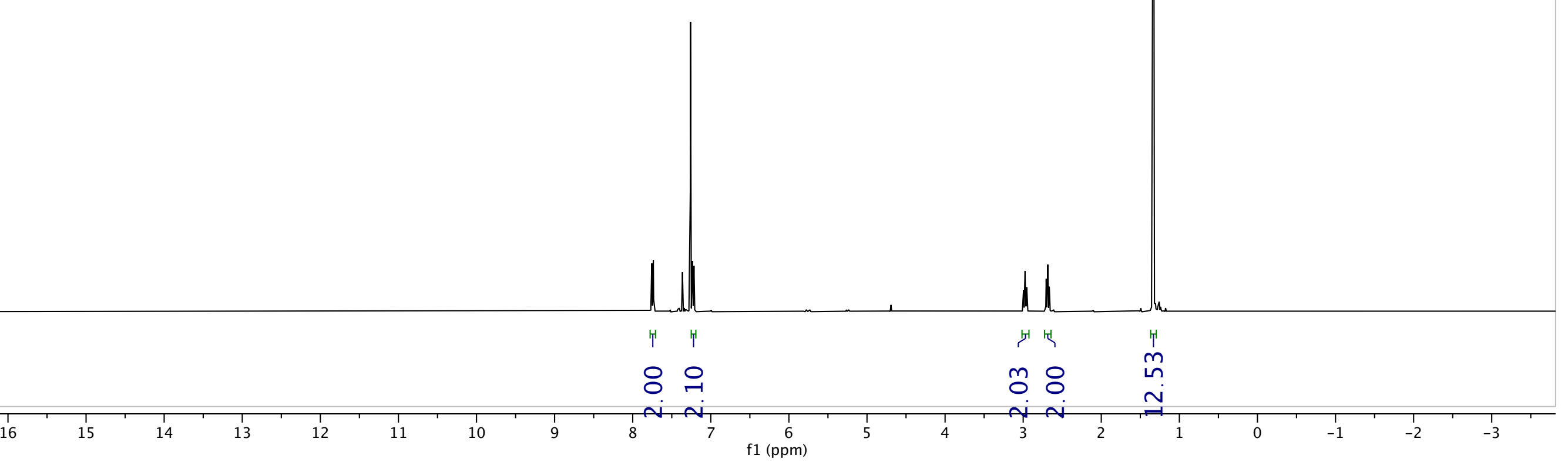


<smiles>O=C(O)CCc1ccc(CO)cc1</smiles>

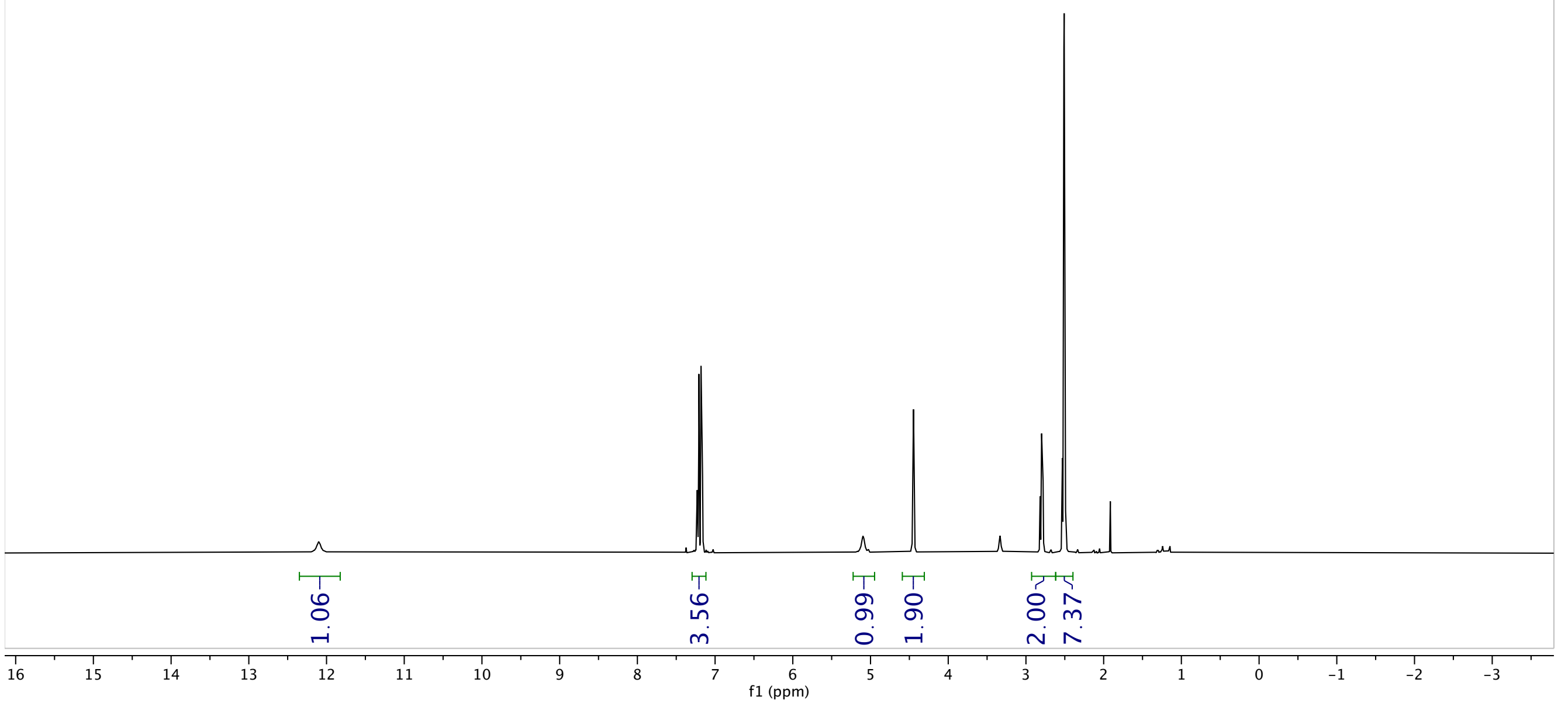



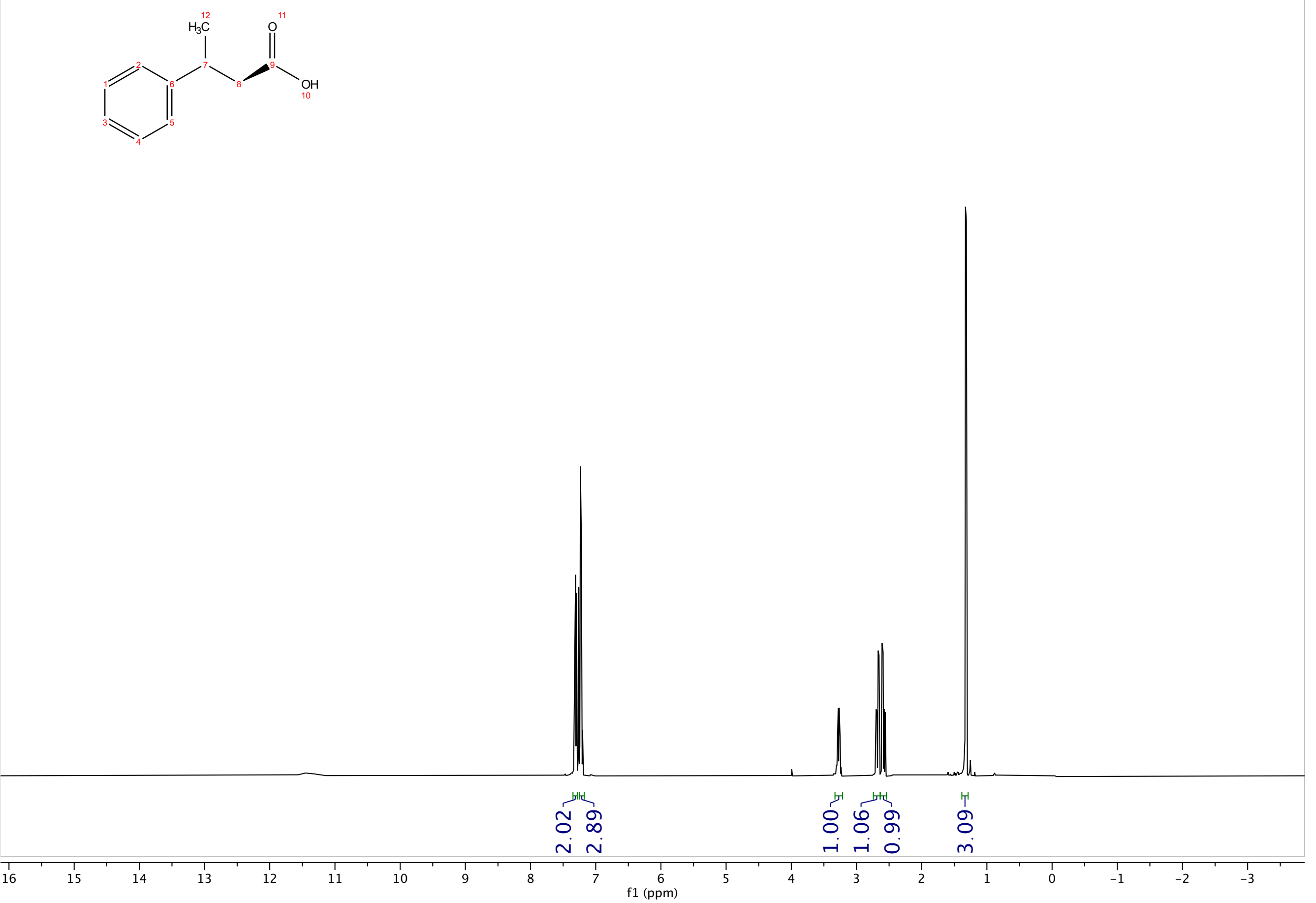

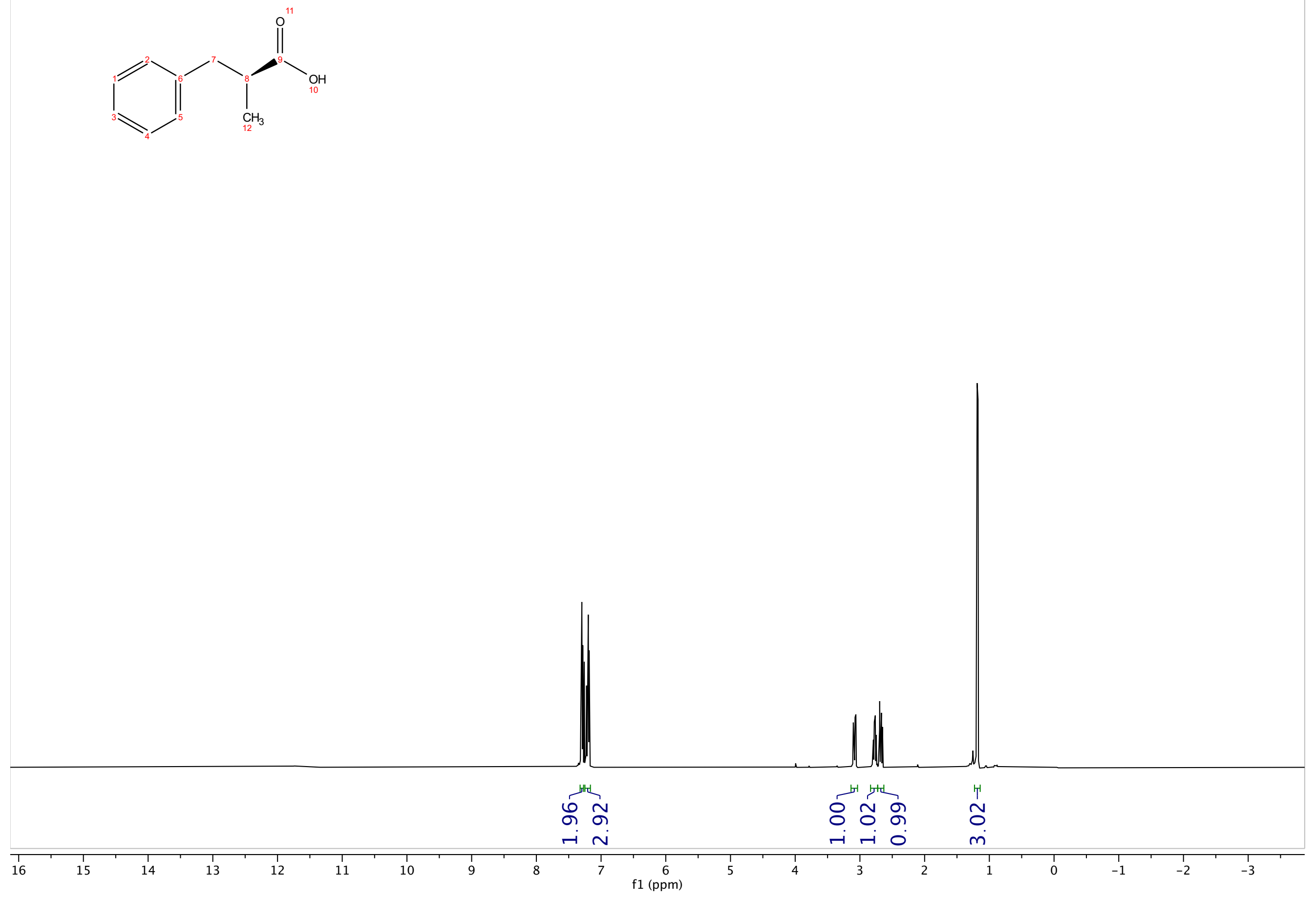

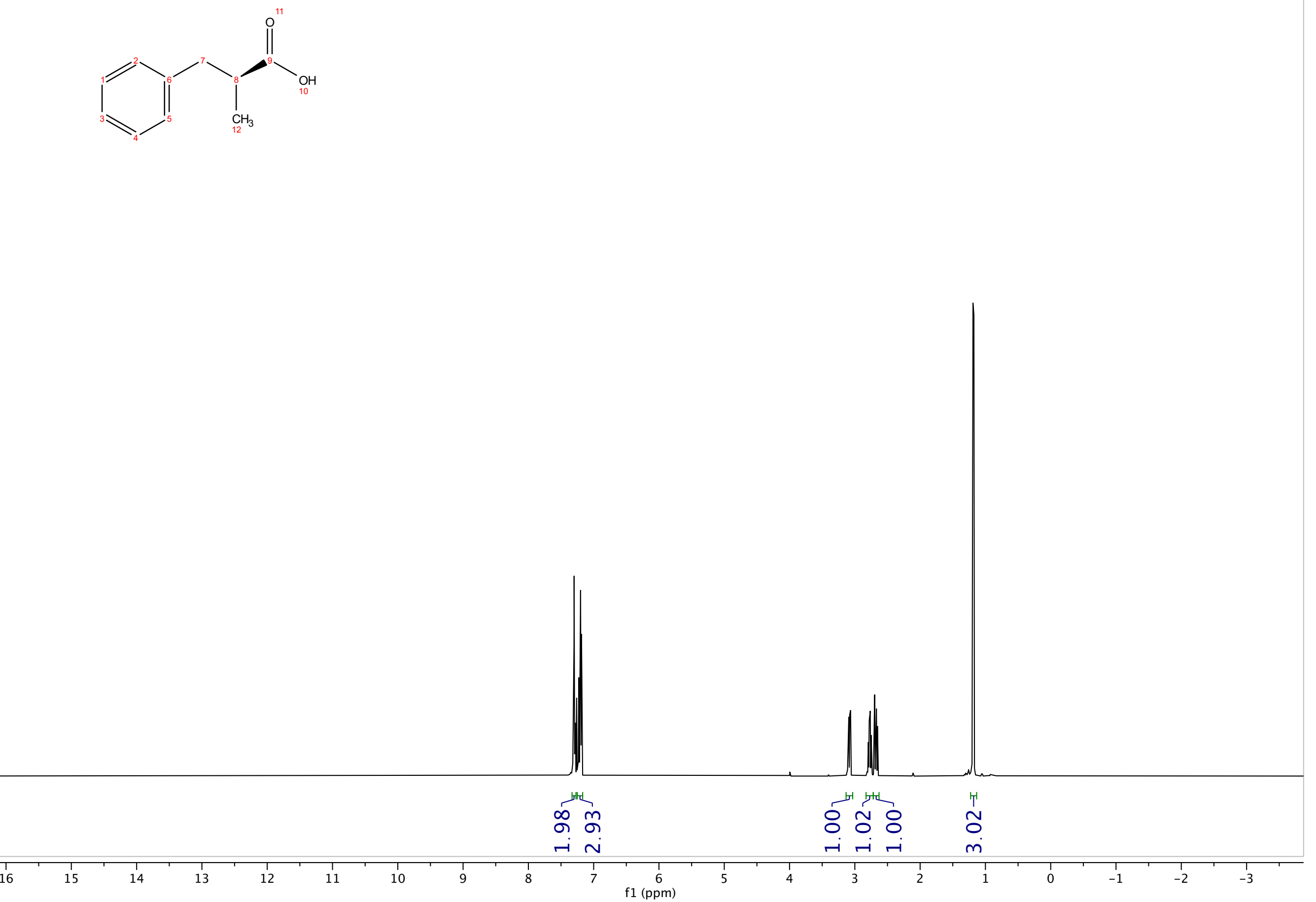

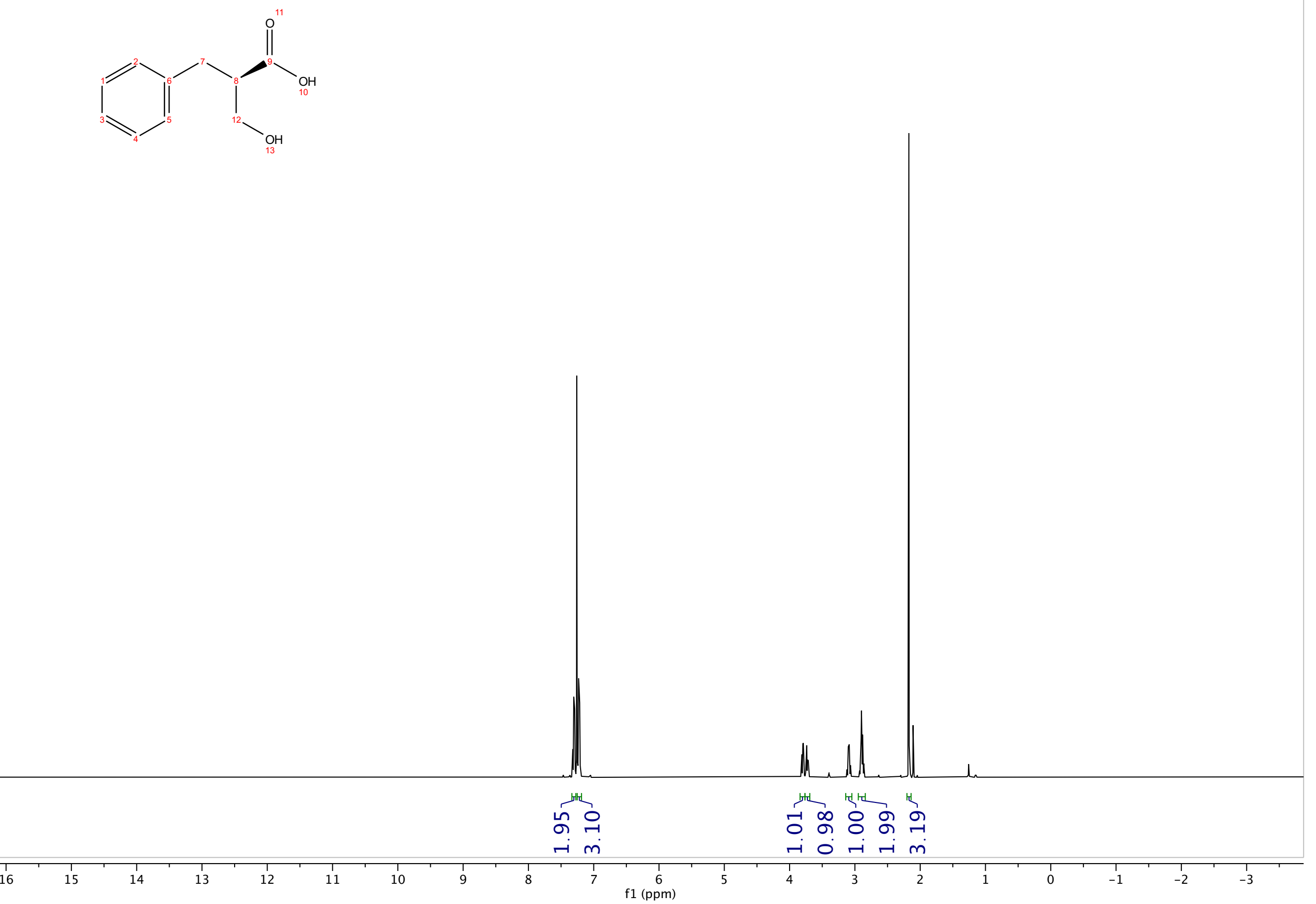
H1_standard.UW CDCl3 /home/alektiar/av400 alektiar 1
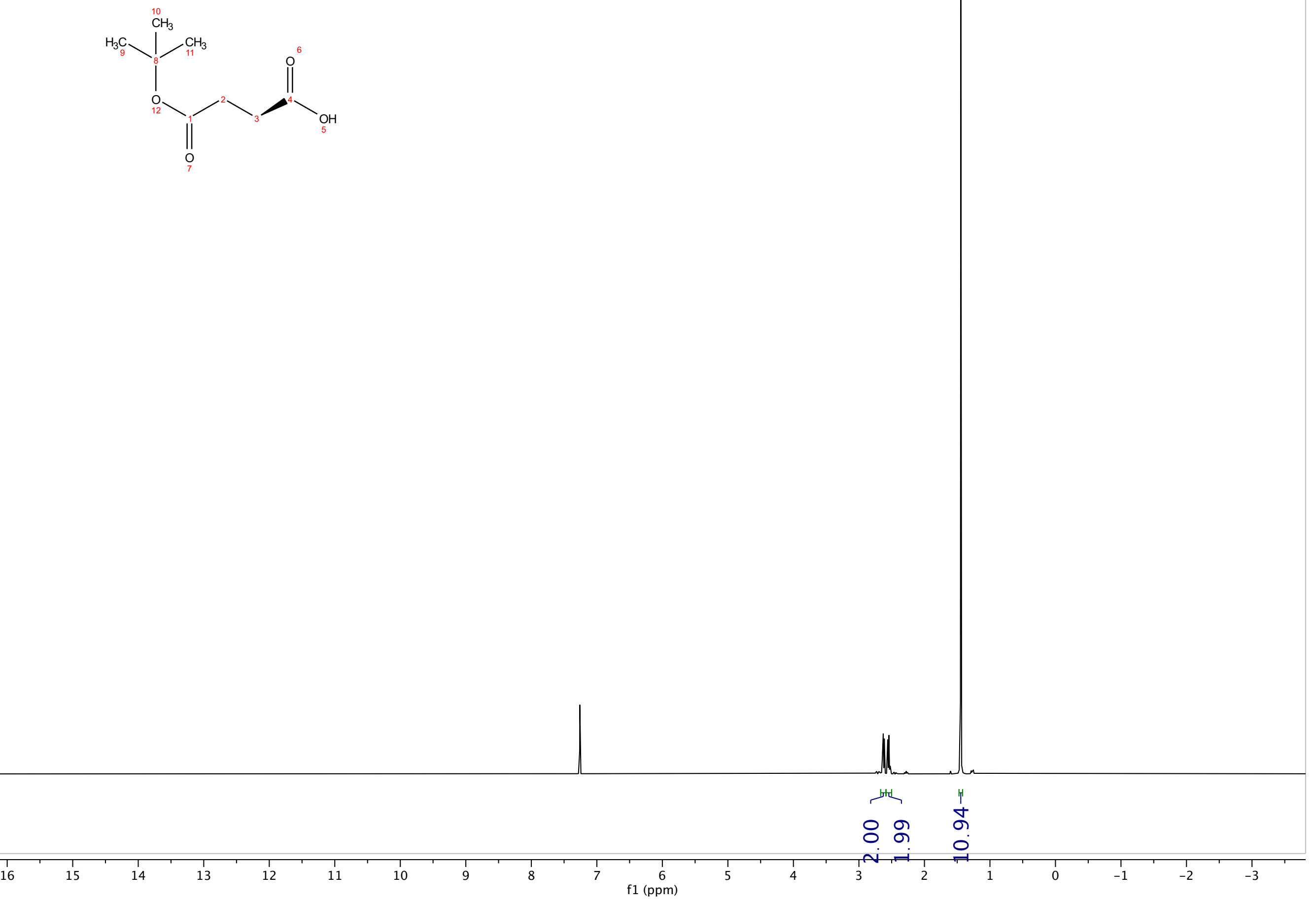
<smiles>CCOC(=O)I(C)SC(=O)O</smiles>

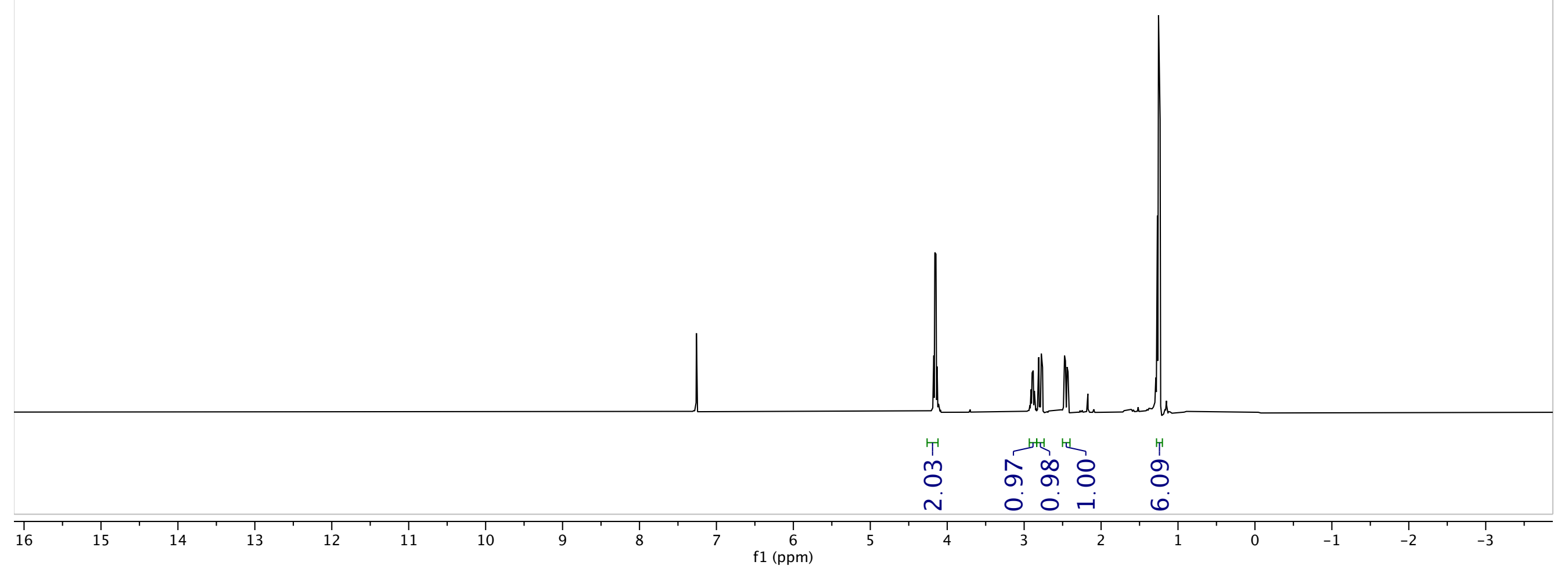


PROTON_D1_2.mk (zg30)<smiles>COOC(=O)[IH][SH](C)C(=O)O</smiles>

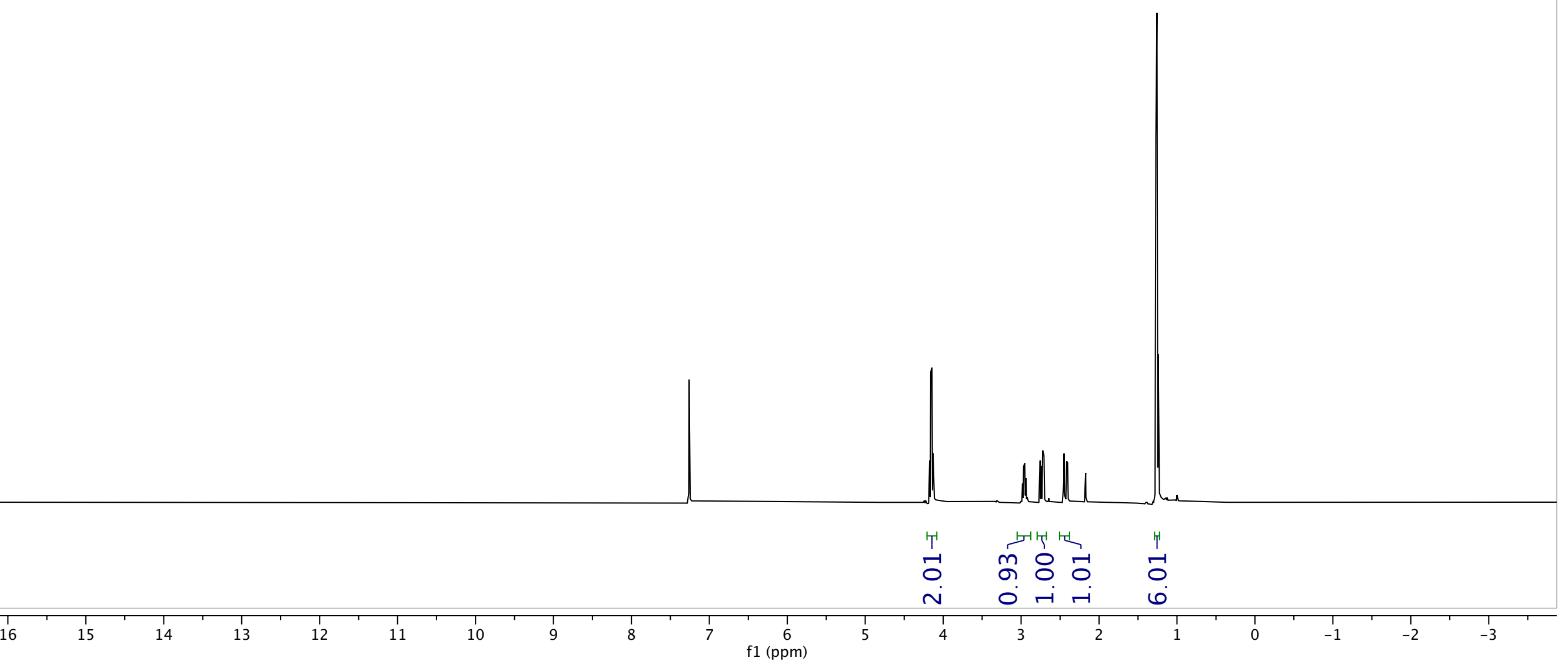



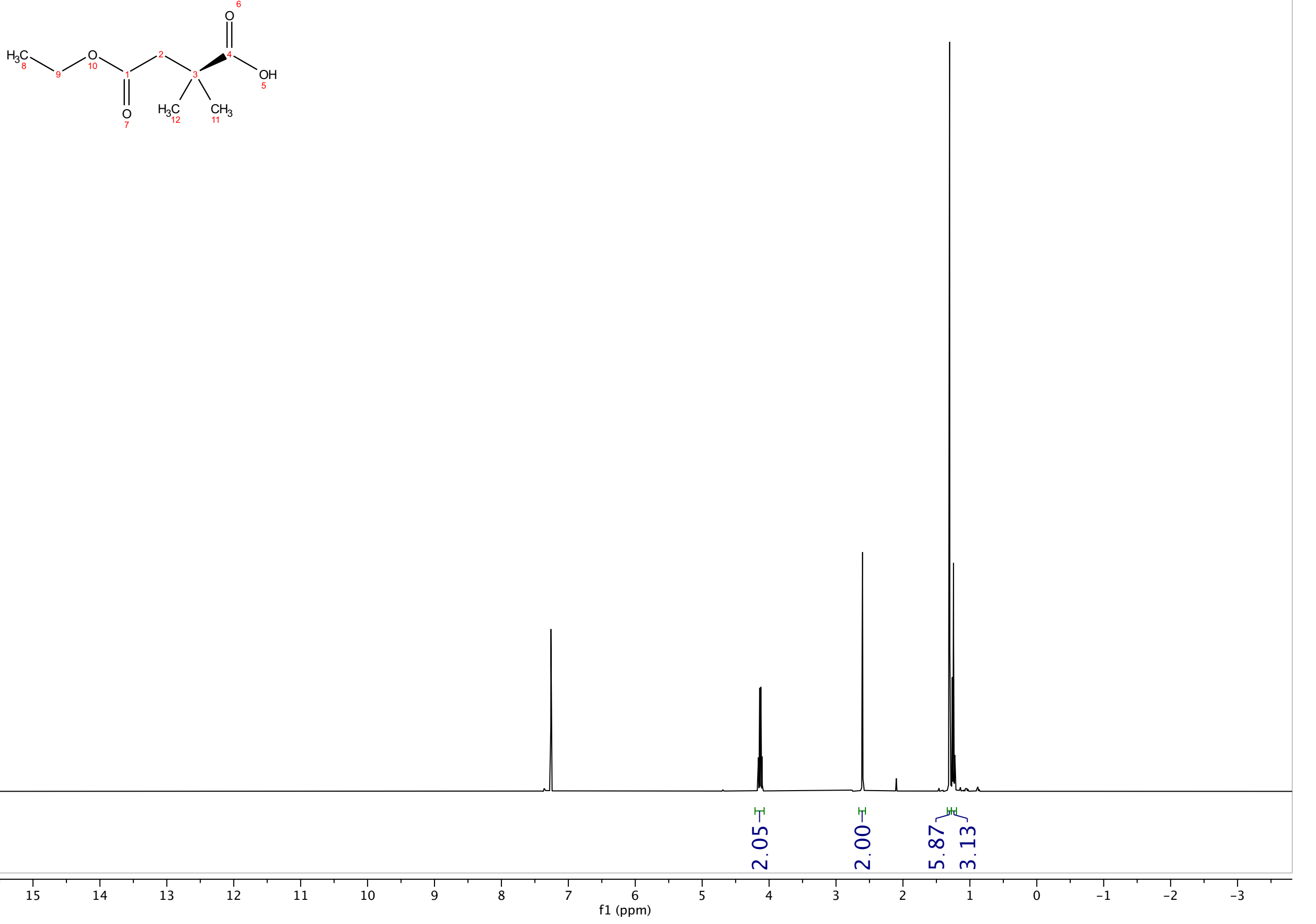
<smiles>CSOC(=O)SI(C)(C)(C)C(=O)O</smiles>
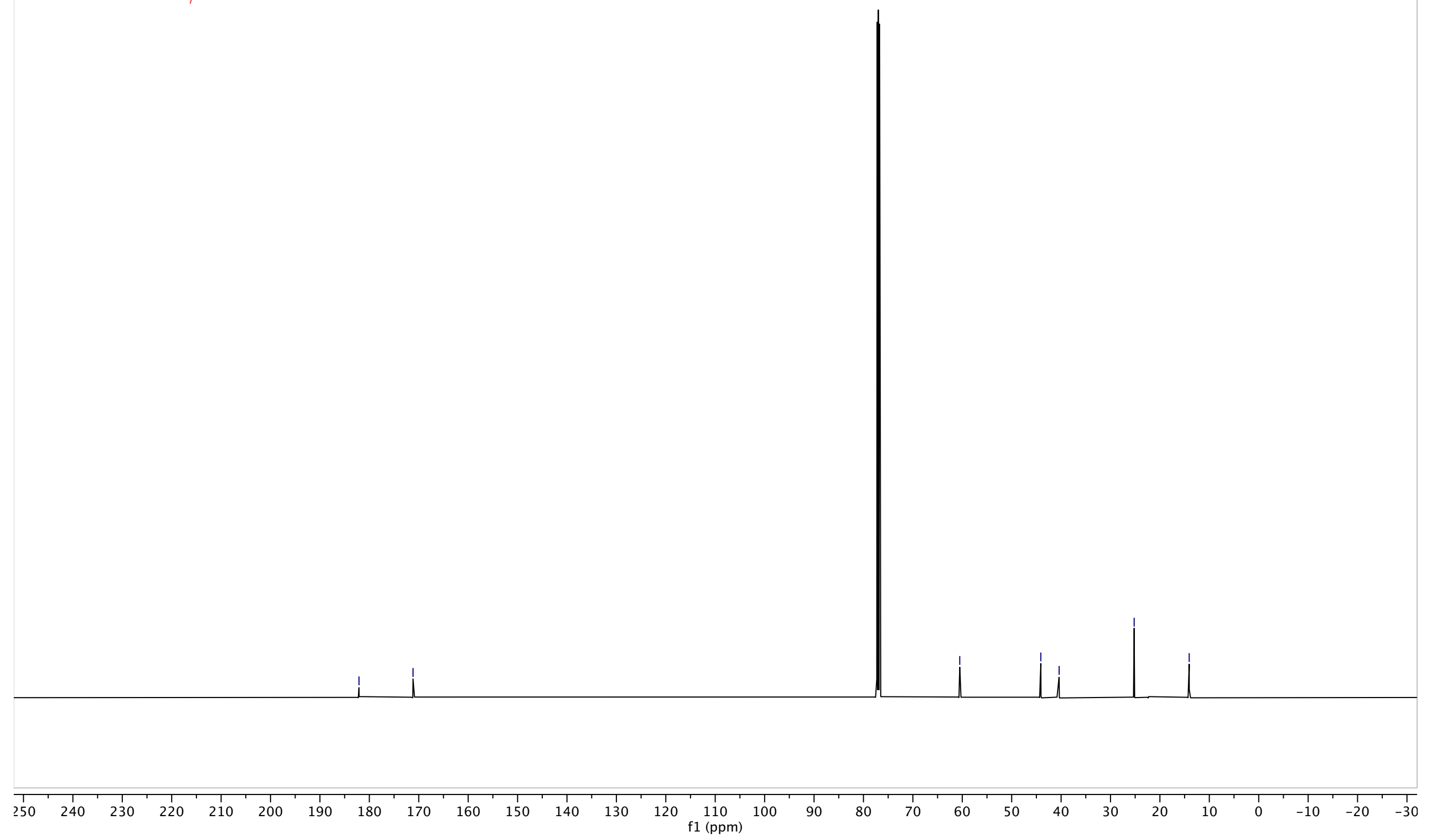
<smiles>CNOP(=O)(O)[C@]1(C(=O)O)CNOOC1</smiles><smiles>CCOC(=O)N(C(=O)O)[14C](=O)O[14CH3]</smiles>

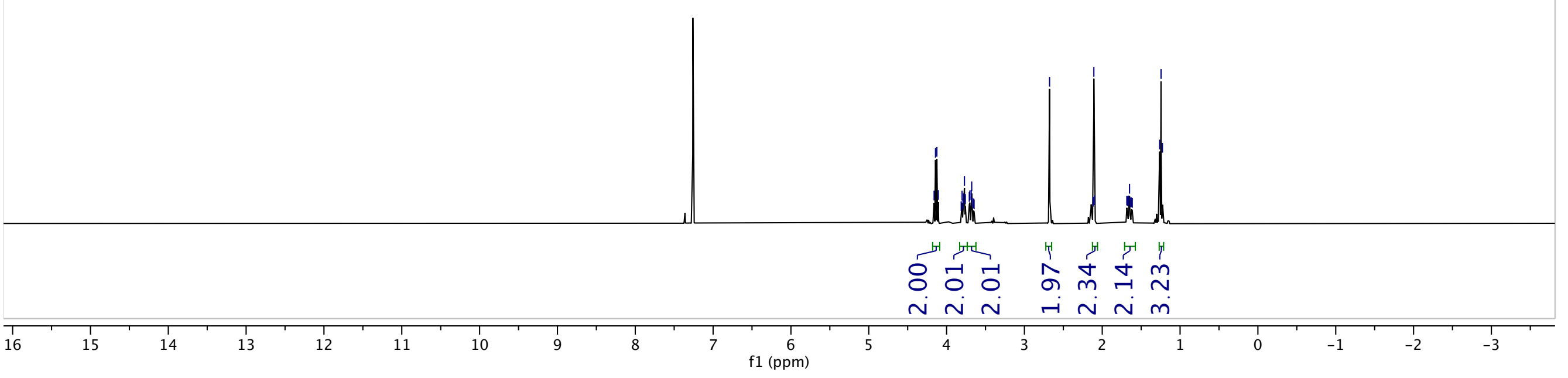


alektiar_2105221243_10_SNA-4-169_f26-35_13C.10_fid SNA-4-169_f26-35_13C

C13_standard.UW CDCI3 /home/alektiar/callisto COVIB̈ं 32


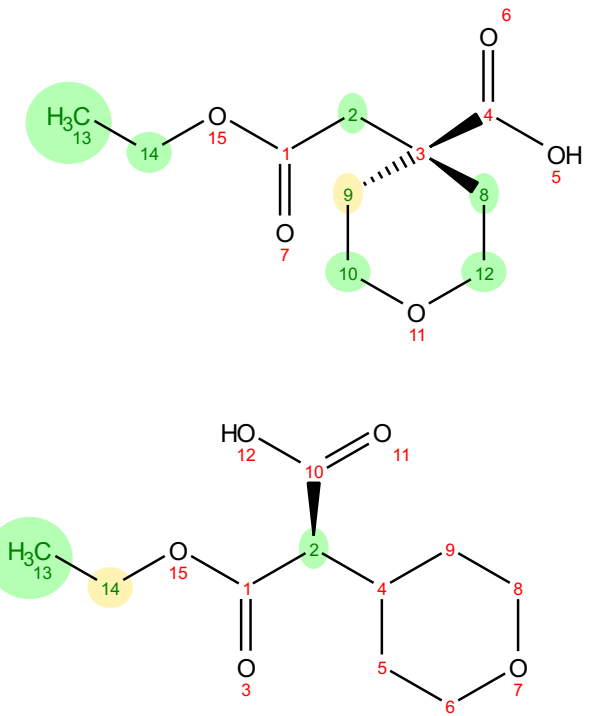

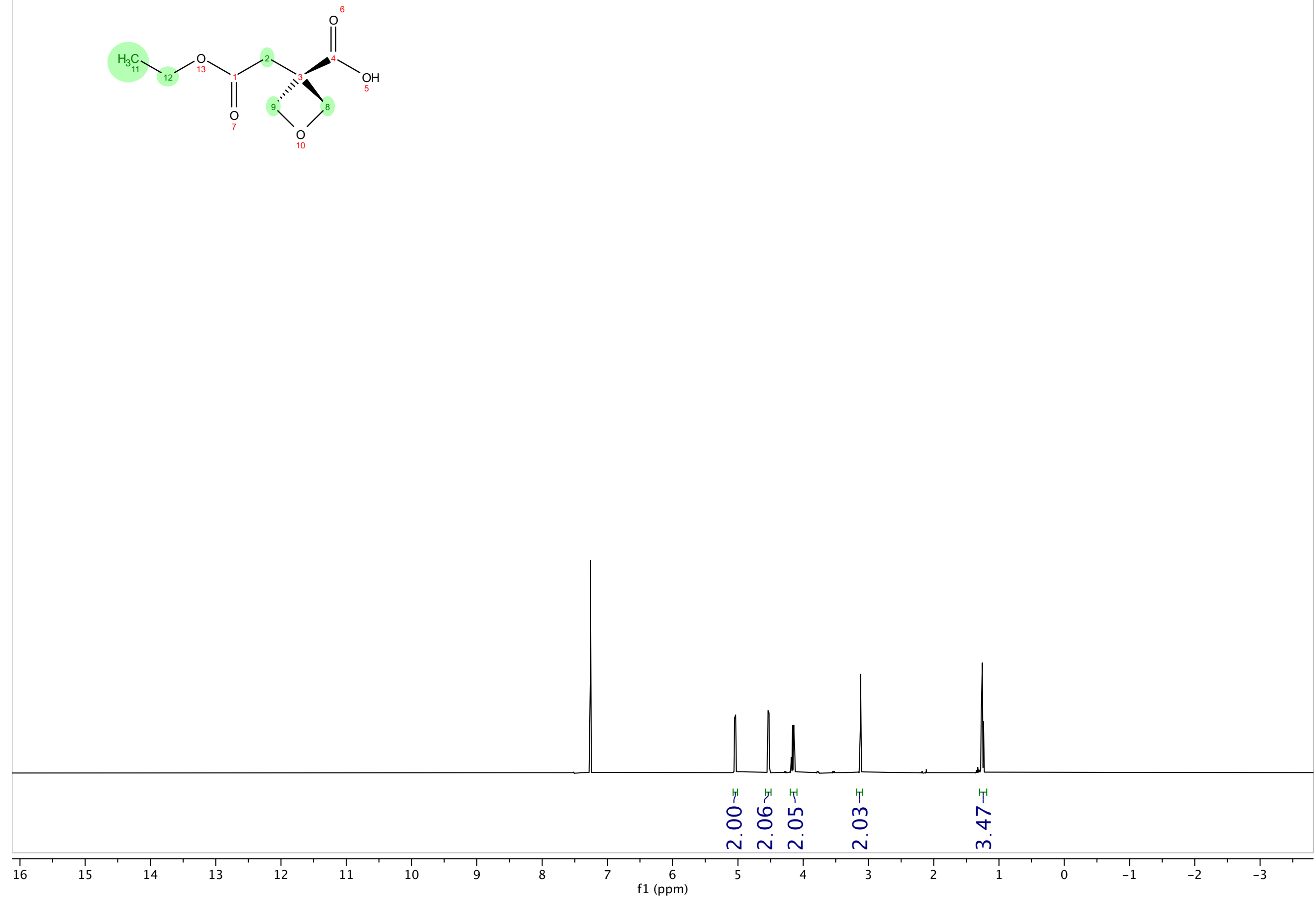


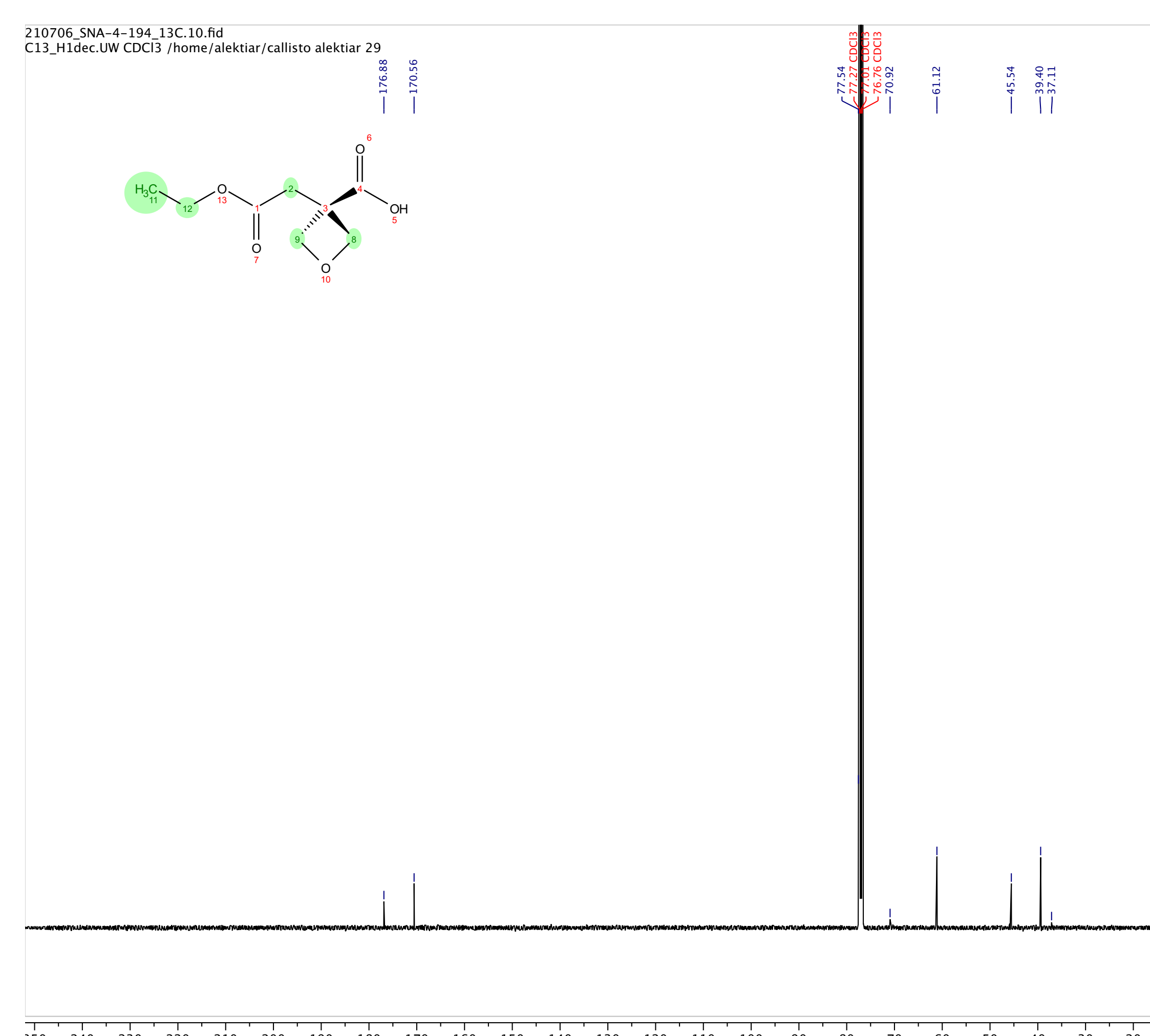


1_standard.UW CDCl3/home/alektiar/av400 COVID $\{5$ A1 - 501\}<smiles>C=POOC(=O)I(C)SC(=O)O</smiles>

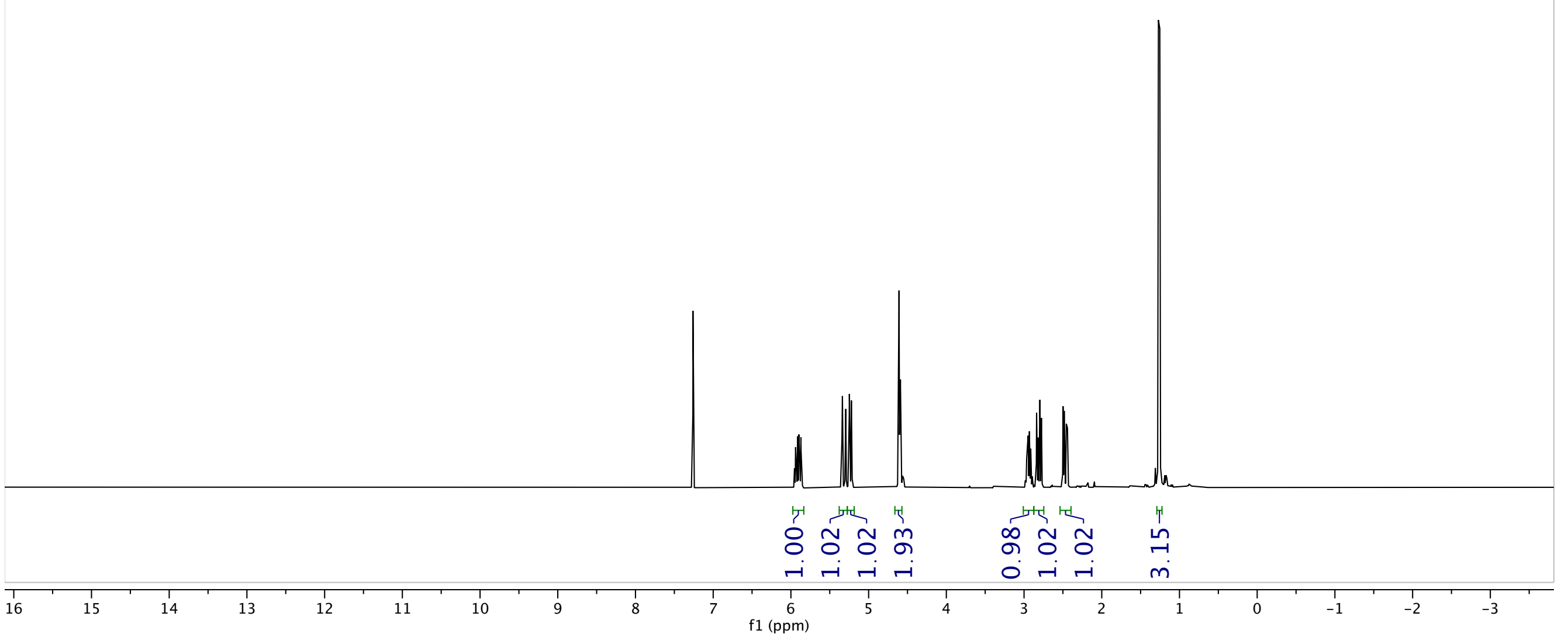


<smiles>C=PSOC(=O)I(C)SP(=O)(O)O</smiles>

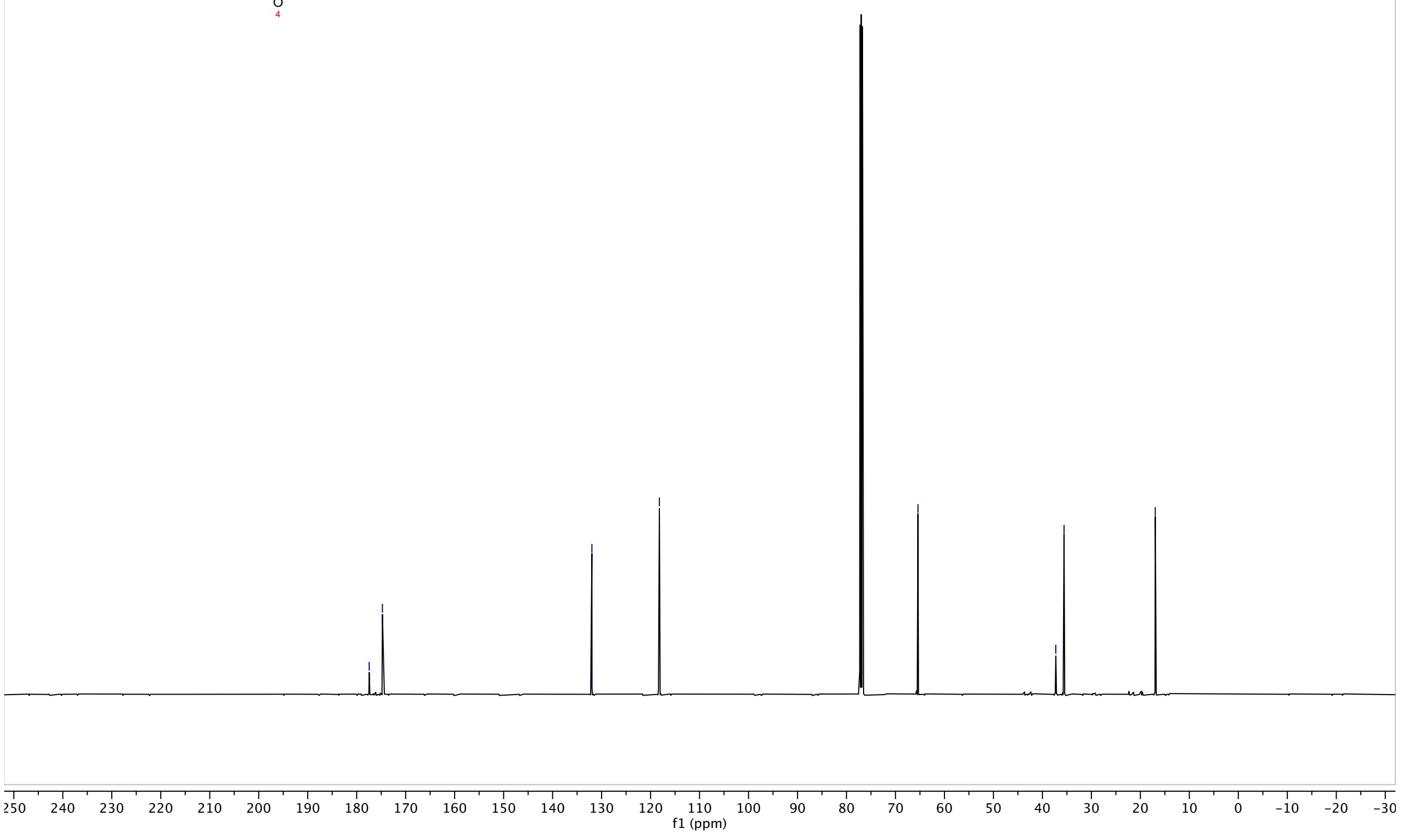


210713_SNA-4-249_dry.10.fid

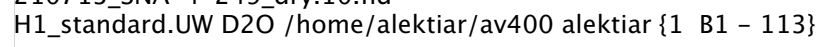

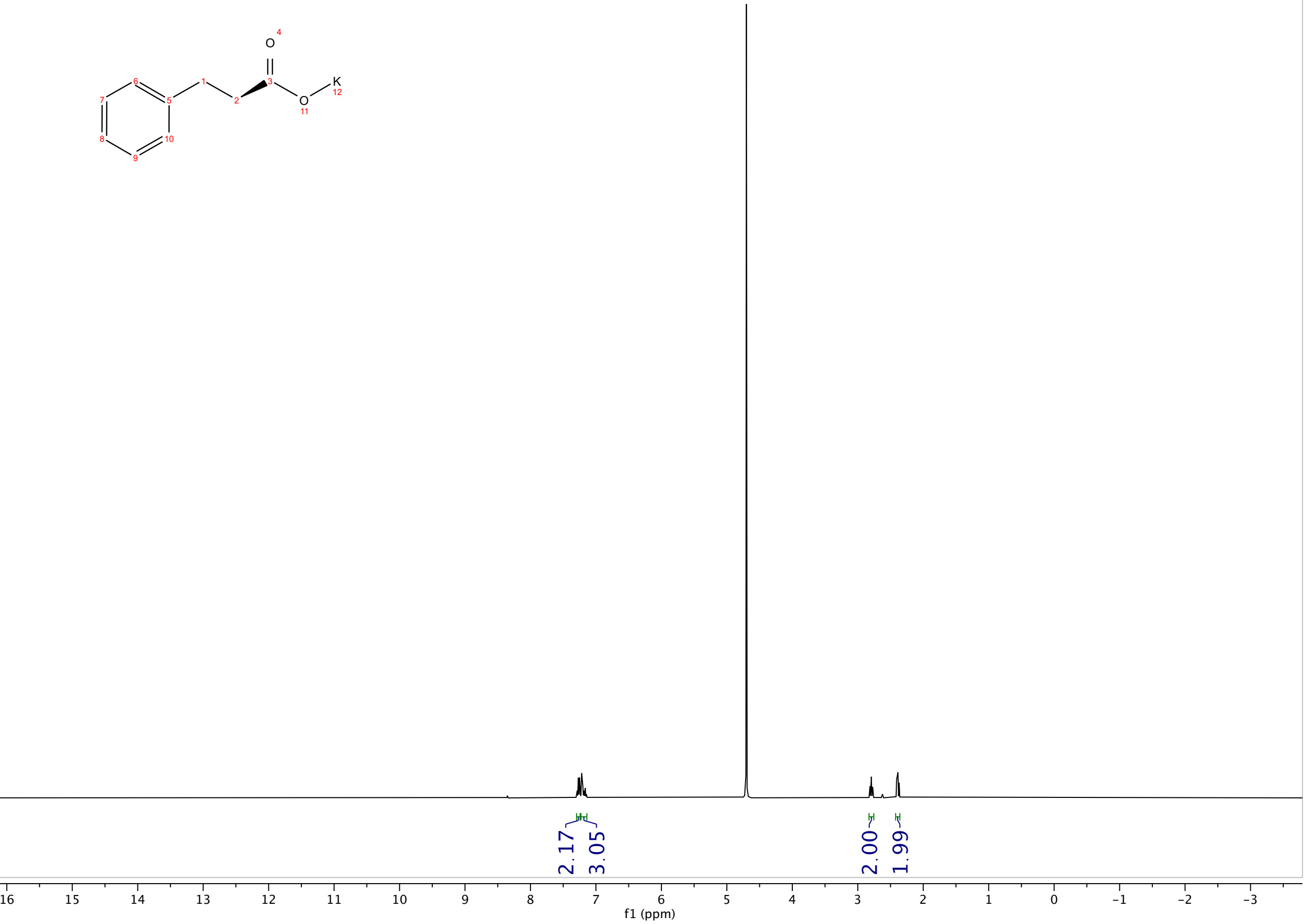

